\title{
Equipment Concepts for Dry Intercask Transfer of Spent Fuel
}

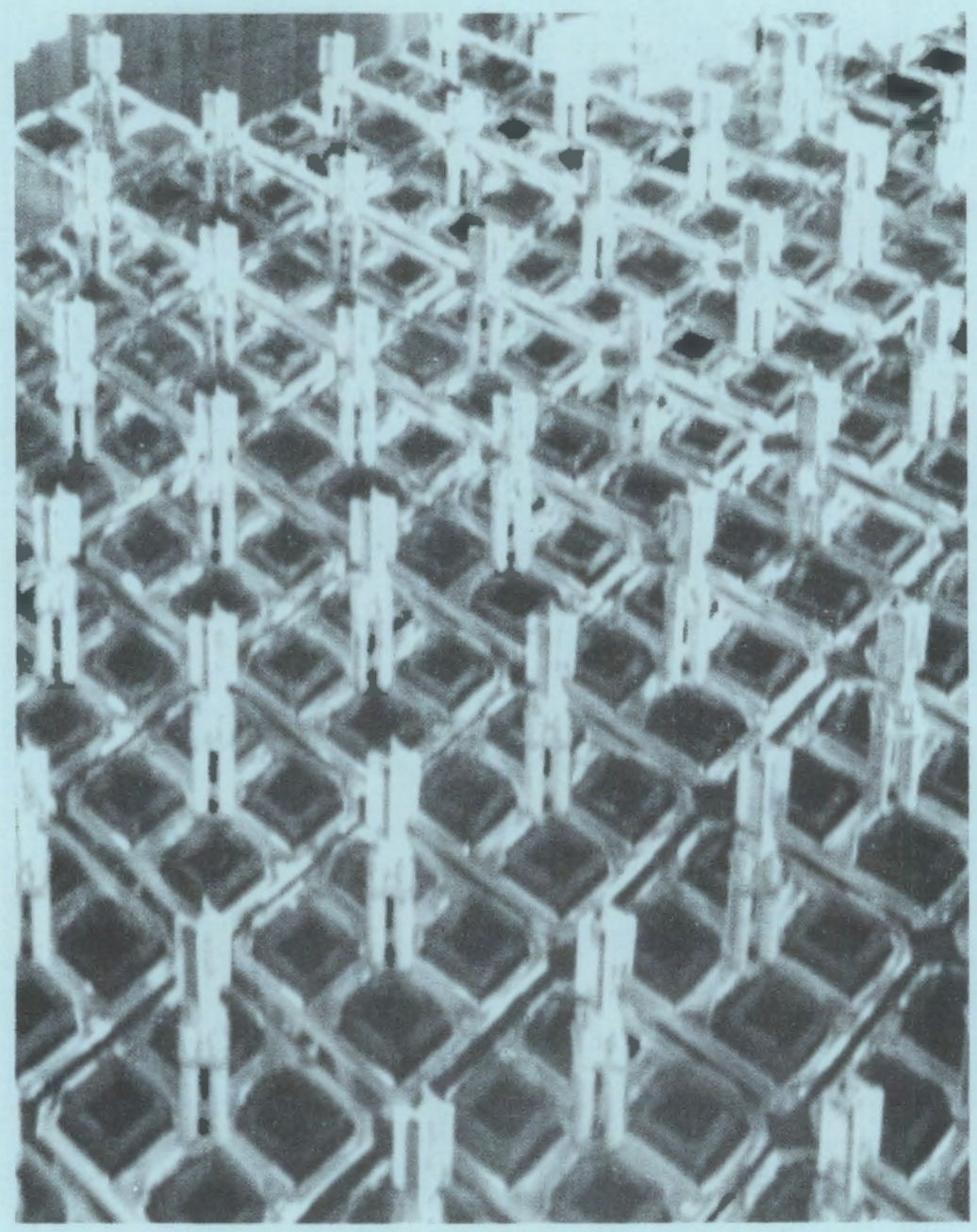

July 1983

Prepared for the U.S. Department of Energy under Contract DE-AC06-76RLO 1830

Pacific Northwest Laboratory

Operated for the U.S Department of Energy by Battelle Memorial Institute 


\title{
DISCLAIMER
}

This report was prepared as an account of work sponsored by an agency of the United States Government. Neither the United States Government nor any agency thereof, nor any of their employees, makes any warranty, express or implied, or assumes any legal liability or responsibility for the accuracy, completeness, or usefulness of any information, apparatus, product, or process disclosed, or represents that its use would not infringe privately owned rights. Reference herein to any specific commercial product, process, or service by trade name, trademark, manufacturer, or otherwise, does not necessarily constitute or imply its endorsement, recommeridation, or favoring by the United States Government or any agency thereof. The views and opinions of authors expressed herein do not necessarily state or reflect those of the United States Government or any agency thereof.

\author{
PACIFIC NORTHWEST L.ABORATORY \\ operated by \\ BATTELLE \\ for the \\ UNITED STATES DEPARTMENT OF ENERGY \\ under Contract DE-AC06-76RLO 1830
}

\begin{tabular}{|c|c|}
\hline \multicolumn{2}{|c|}{ Printed in the United States of America } \\
\hline \multicolumn{2}{|c|}{ Available from } \\
\hline \multirow{2}{*}{\multicolumn{2}{|c|}{$\begin{array}{l}\text { National Technical Information Service } \\
\text { United States Deparıment of Commerce }\end{array}$}} \\
\hline & \\
\hline \multicolumn{2}{|c|}{5285 Port Royal Road } \\
\hline \multicolumn{2}{|c|}{ Springfield, Virginia 22151} \\
\hline \multirow{2}{*}{\multicolumn{2}{|c|}{$\begin{array}{l}\text { NTIS Price Codes } \\
\text { Microfiche A01 }\end{array}$}} \\
\hline & \\
\hline \multicolumn{2}{|c|}{ Printed Copy } \\
\hline & Price \\
\hline Pages & Codes \\
\hline $001-025$ & $\mathrm{~A} 02$ \\
\hline $026-050$ & $\mathrm{~A} 03$ \\
\hline 051-075 & A04 \\
\hline $076-100$ & A05 \\
\hline $10 ?-125$ & A06 \\
\hline $126-150$ & A07 \\
\hline $151-175$ & $\mathrm{~A} 0 \mathrm{~B}$ \\
\hline $176-200$ & $\mathrm{~A} 09$ \\
\hline $201-225$ & A010 \\
\hline $226-250$ & A011 \\
\hline $251-275$ & A012 \\
\hline $276-300$ & A013 \\
\hline
\end{tabular}


EOUIPMENT CONCEPTS FOR DRY INTERCASK TRANSFER OF SPENT FUEL

K. J. Schneider

July 1983

Prepared for U.S. Department of Energy under Contract OE-ACO6-76RLO 1830

Pacific Northwest Laboratory

Richland, Washington 99352 


\section{,}

. 


\section{ABSTRACT}

One or more federal government sites may provide interim storage for spent fuel from commercial nuclear power reactors that have used up their available storage capacity. One of the leading candidate concepts for this interim storage is to place spent fuel in large metal shielding casks containing dry air or inert gas. The Federal Interim Storage (FIS) site may not have the capability to transfer spent fuel from transportation casks to storage casks and vice versa. Thus, there may be an incentive to construct a relatively inexpensive but reliable intercask transfer system for use at an FIS site. This report documents the results of a study of preconceptual design and analysis of four intercask transfer concepts.

The four concepts are: 1) a large shielded cylindrical turntable that contains an integral fuel handling machine (turntable concept); 2) a shielded fuel handling machine under which shipping and storage casks are moved horizontally (shuttle concept); 3) a small hot cell containing equipment for transferring fuel between shipping and storage casks (that enter and leave the cell on carts) in a bifurcated trench (trench concept); and 4) a large hot cell, shielded by an earthen berm, that houses equipment for handling fuel between casks that enter and leave the cell on a single cart (igloo concept).

The casks considered in this study are most of the transport casks currently operable in the U.S.A., and the storage casks designated REA-2023 and GNS Castor-V.

Exclusive of basic services assumed to be provided at the host site, the design and capital costs are estimated to range from $\$ 9$ to $\$ 13$ million. The portion of capital costs for portable equipment. (for potential later use at another site) was estimated to range from $70 \%$ to $98 \%$, depending on the concept. Increasing portability from a range of $70-90 \%$ to $98 \%$ adds $\$ 2-4$ million to the capital costs. Operating costs are estimated at about $\$ 2$ million/year for all concepts. Implementation times range from about 18 months for the more conventional systems to 40 months for the more unique systems. Times and costs for relocation to another site are 10 t.o 14 months and about $\$ 1$ million, plus shipping costs and costs of new construction at the new site. Al1 concepts have estimated capacities for fuel transfer at least equal to the 
criterion set for this study. Only the hot cell concepts have capability for recanning or repair of canisters. Some development is believed to be required for the turntable and shuttle concepts, but none for the other two concepts.

It is believed that sufficient information has been developed in this study to provide the bases for initiating optimizing and design efforts. 


\section{CONTENTS}

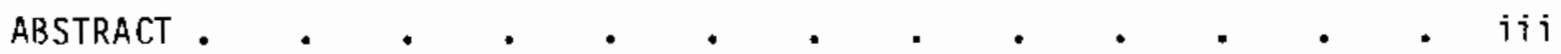

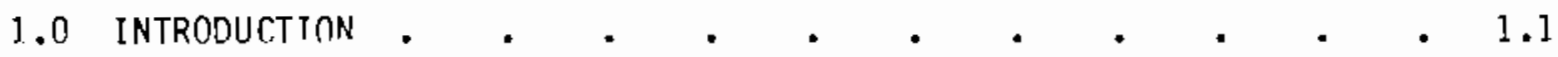

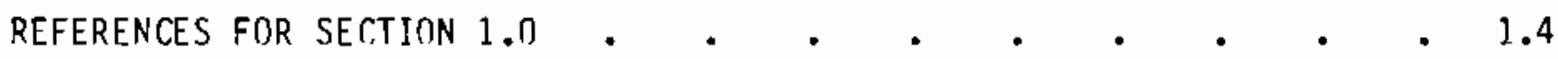

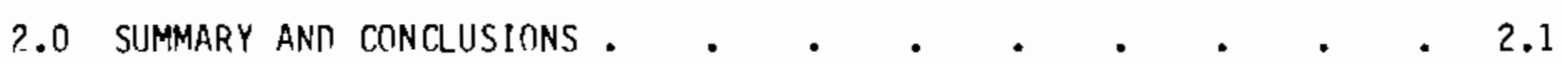

2.1 SUMMARY . . . . . . . . . . . . . . . . 2.2

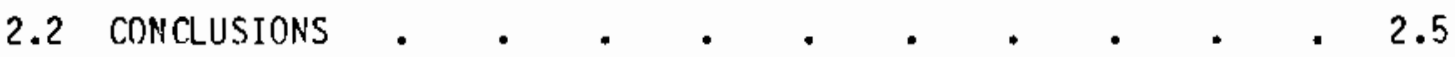

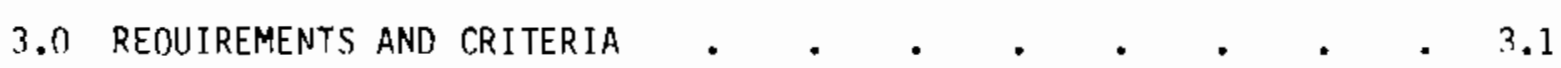

3.1 CAPABILITIES AT THE HOST SITE $\quad$ • $\quad$ • $\quad$ • $\quad$ • $\quad 3.1$

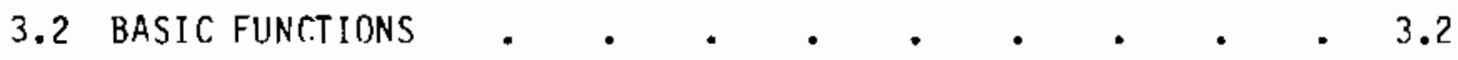

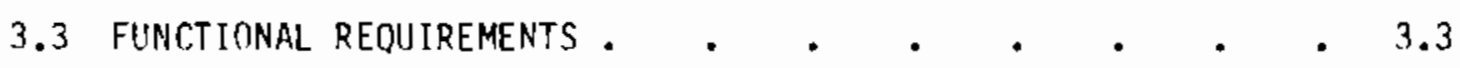

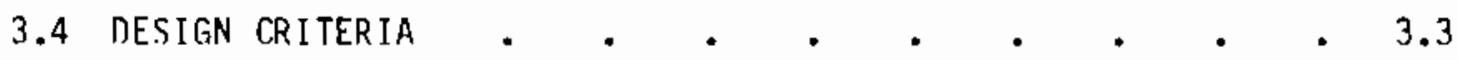

REFERENCES FOR SECTION $3.0 \quad$.

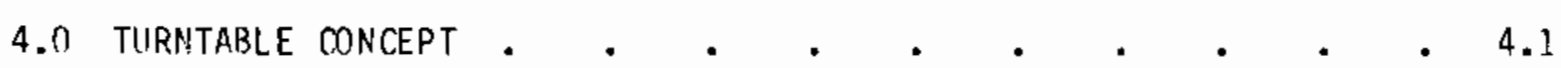

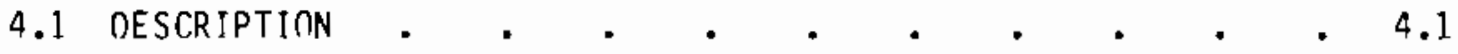

4.1 .1 Site $. \quad . \quad . \quad . \quad . \quad . \quad . \quad . \quad .4 .1$

4.1 .2 Outer Enclosure.$\quad$. $\quad . \quad$. . . . . . 4.5

4.1.3 Cask and Fuel Handling . . . . . . . 4.5

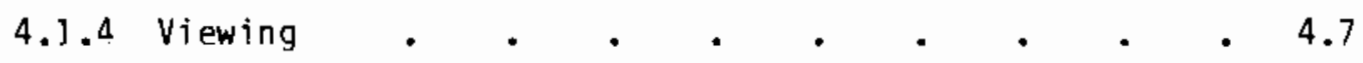

4.1 .5 Ventilation . $\quad . \quad$. . . . . . . 4.7

4.1.6 Mecontamination and Contamination Control . . . 4.8

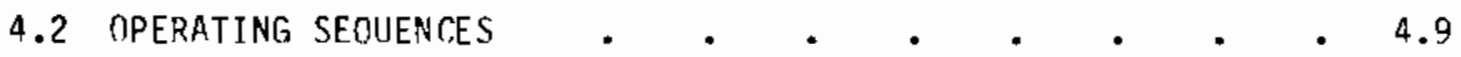

4.3 SYSTEM CAPACITY . . . . . . . . . . . . . 4.9

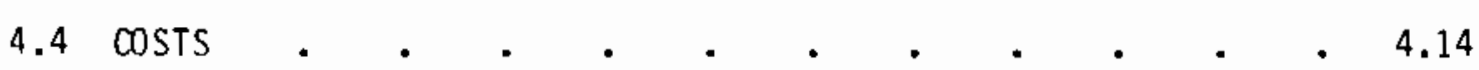

4.4.1 Design, Construction, and Shakedown Costs . . . 4.14 
4.4.2 Operating Costs . . . . . . . . 4.14

4.4.3 Relocation Costs . . . . . . . . . 4.17

4.5 IMPLEMENTATION SCHEDULE • • • • • • • • • • . 4.18

REFERENCES FOR SECTION 4 .

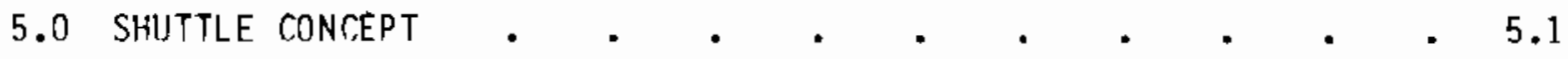

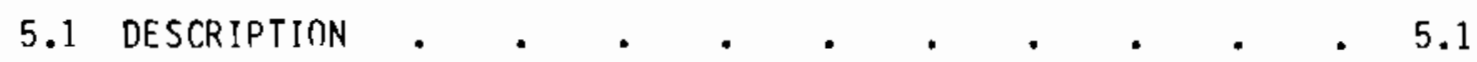

5.1 .1 Site . . . . . . . . . . . 5.1

5.1 .2 Outer Enclosure . . . . . . . . . . 5.5

5.1 .3 Cask and Fuel Handling . . . . . . . 5.5

5.1 .4 Viewing $\quad . \quad$. $\quad . \quad$. $\quad . \quad . \quad 5.7$

5.1 .5 Ventilation. . . . . . . . . . 5.7

5.1.6 Decontamination and Contamination Control . . . 5.8

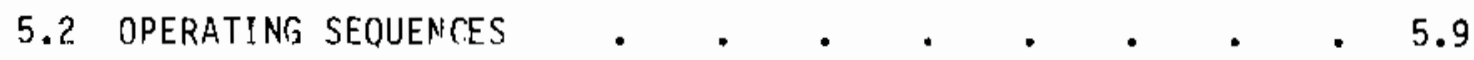

5.3 SYSTEM CAPACITY $. \quad . \quad . \quad . \quad . \quad . \quad . \quad . \quad$. 5.11

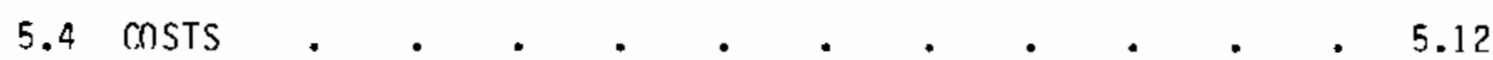

5.4.1 Design, Construction, and Shakedown Costs . . . 5.12

5.4 .2 Operating Costs . . . . . . . . 5.12

5.4.3 Relocation Costs . . . . . . . . 5.12

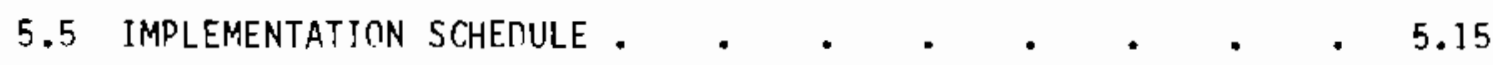

REFERENCES FOR SECTION 5 . $5 . \quad$.

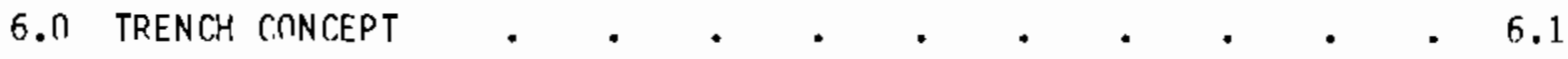

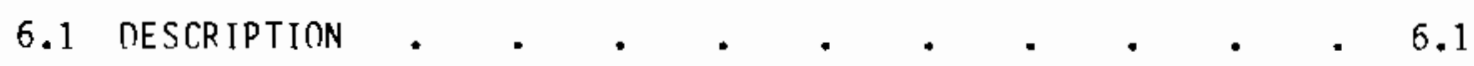

6.1 .1 Site $. \quad . \quad . \quad . \quad . \quad . \quad . \quad . \quad .6 .1$

6.1 .2 Duter Enclosure . . . . . . . . . . 6.5

6.1 .3 Cask and Fuel Handling . . . . . . . 6.5

6.1 .4 Viewing $\quad . \quad$. $\quad . \quad . \quad . \quad . \quad . \quad 6.7$ 
6.1 .5 Ventilation . . . . . . . . . . . 6.7

6.1.6 Decontamination and Contamination Control . . 6.7

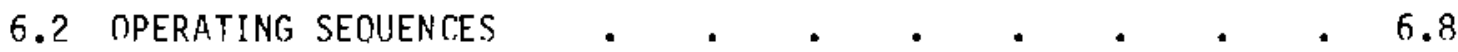

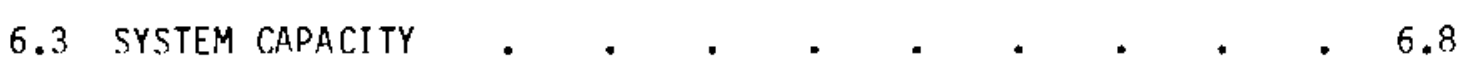

6.4 COSTS $\quad . \quad . \quad . \quad . \quad . \quad . \quad .6 .11$

6.4.1 Design, Construction, and Shakedown Costs . . . 6.12

6.4 .2 Operating Costs . . . . . . . . 6.12

6.4.3 Relocation Costs. . . . . . . . . 6.12

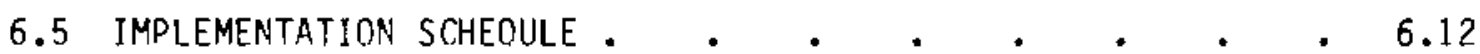

REFERENCES FOR SECTION 6 . 6 .

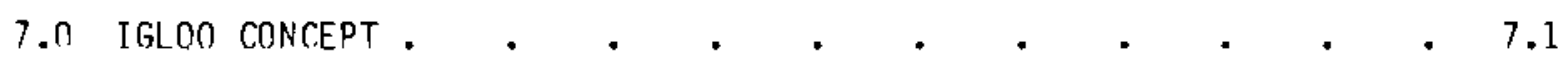

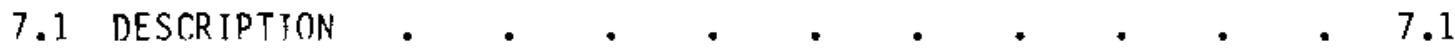

7.1 .1 Site $. \quad . \quad . \quad . \quad . \quad . \quad . \quad . \quad . \quad$. 7.1

7.1 .2 Outer Enclosure $. \quad . \quad . \quad . \quad . \quad . \quad$. 7.5

7.1.3 Cask and Fuel Handling . . . . . . . 7.6

7.1 .4 Viewing $\quad . \quad$. . . . . . 7.7

7.1 .5 Ventilation . . . . . . . . . . 7.7

7.1.6 Decontamination and Contamination Control . . . 7.8

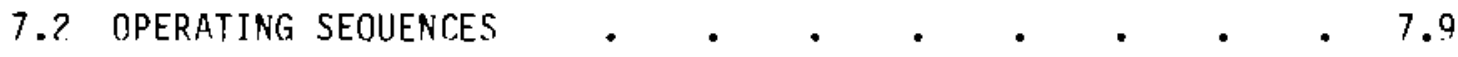

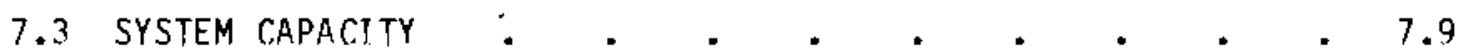

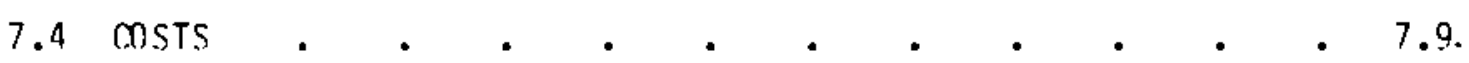

7.4.1 Design, Construction and Shakedown Costs . . $\quad$. 7.11

7.4 .2 Operating Costs . $\quad . \quad$. $\quad . \quad$. 7.11

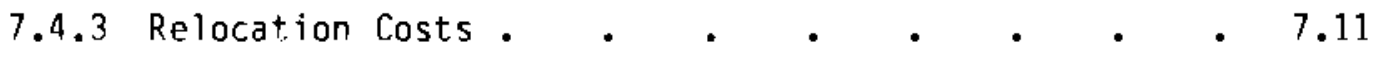

7.5 IMPLementation SCHEDULE • • • • • • • • • • 7.14

REFERENCES FOR SECTION 7 . 7 . 
APPENDJX A - GENERAL DESCRIPTION OF TRANSPORT CASKS FOR

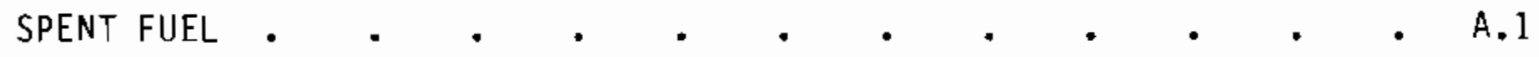

REFERENCE FRR APPENDIX A

APPENDIX B - REFERENCE DESCRIPTION OF METAL STORAGE CASKS • • • - B. B.

REFERENCES FRR APPENDTX B

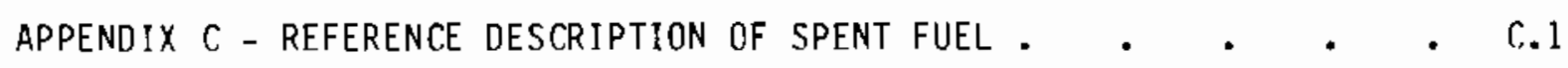

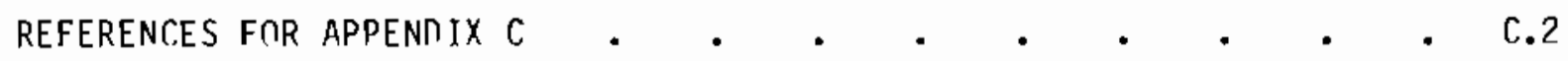

APPENDIX $\Pi$ - REFERENCE HIGH LEVEL WASTE CANISTER ANN ITS

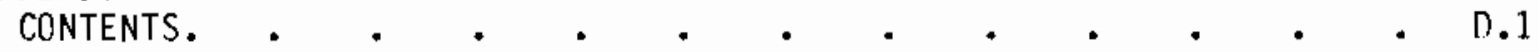

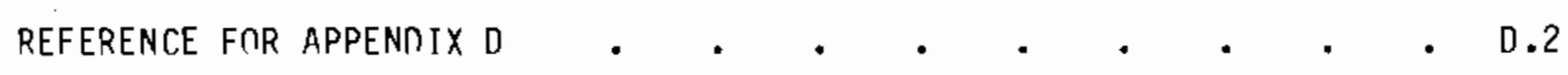

APPEADIX E - COST ESTIMATING DETAILS AND BASES FOR THE

REFERENCES FOR APPFNTTX E

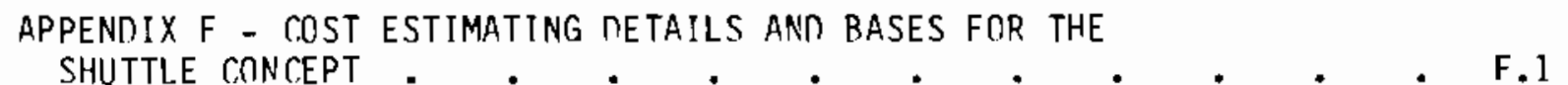

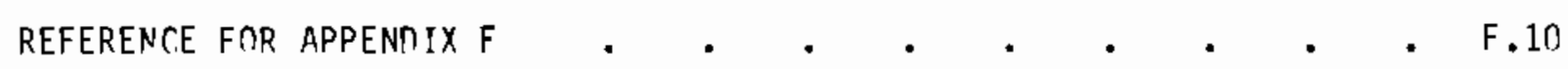

APPENOIX G - COST ESTIMATING NETAILS ANN RASES FOR THE

REFERENCES FOR APPENIIX G

APPENDIX H - COST ESTIMATING DETAILS AND BASES FOR THE
IGLOO CONCEPT
$\bullet$

REFERENCES FOR APPENDIX H 


\section{FJGIJRES}

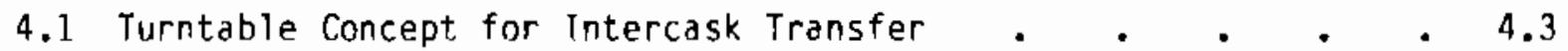

4.2 Cask Movement Sequence for Loading a Storage Cask -

Turntable Concept • • • • • • • . • . 4.11

4.3 Implementation Schedule for Turntable Concept . . . 4 4.18

5.1 Shuttle Concept for Intercask Transfer . . . . . . 5.3

5.2 Implementation Schedule for Shuttle Concept . . . . 5.15

6.1 Trench Concept for Intercask Transfer . . . . . . . . 6.3

6.2 Implementation Schedule for Trench Concept.$\quad$. $~ 6.16$

7.1 Igloo Concept for Intercask Transfer . . . . . . . 7.3

7.2 Implementation Schedule for Igloo Concept $\quad$ • $\quad$ - $\quad$ • 7.14 


\section{TARLES}

2.1 Summary of General Characteristics of the Intercask

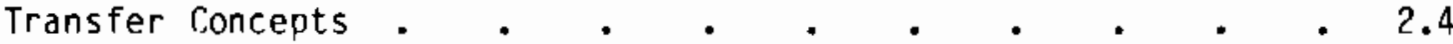

2.2 Summary of Costs of Intercask Transfer Concepts . . . . 2.6

4.1 Operational Sequences in the Turntable Concept . . . . 4.10

4.2 Operating Times for Shipping Cask Turnaround . . . . 4.12

4.3 Capital Cost Sumary for the Turntable Concept . • • . 4.15

4.4 Estimated Operating Staff for the Turntable Concept . . . 4.16

4.5 Operating Cost Summary for the Turntable Concept . . . . 4.16

4.5 Relocation Costs for the Turntable Concept . . . . . 4.17

5.1 Operational Sequences in the Shuttle Concept.$\quad$. $~ . ~ 5.9$

5.2 Capital Cost Summary for the Shuttle Concept . . . . 5.13

5.3 Operating Cost Surmary for the Shuttle Concept . . . . 5.14

5.4 Relocation Costs for Shuttle Concept . . . . . . 5.14

6.1 Operational Sequence in the Trench Concept . . . . . 6.9

6.2 Operating Times for Shipping rask Turnaround . . . . 6.10

6.3 Capital Cost Surmary for the Trench Concept . . . . . 6.13

6.4 Estimated Operating Staff for Trench Concept • • . . 6.14

6.5 nperating Cost Summary for the Trench Concept . . . . 6.14

6.6 Relocation Costs for the Trench Concept . . . . . 6.15

7.1 Operational Sequences in the Igloo Concept . . . . . 7.10

7.2 Capital Cost Summary for the Igloo Concept • . . • • 7.12

7.3 Operating Cost Sumary for the Igloo Concept . . . . 7.13

7.4 Relocation Costs for Igloo Concept . . . . . . 7.13

A.1 General Description of Transport Casks for Spent Fuel . . . A.1

B.1 General Description of Storage Casks . . . . . . B.1 


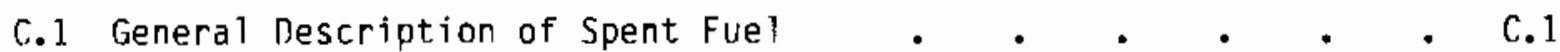

D.1 Design Parameters of a Reference HLW Canister and

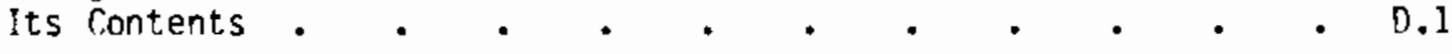





\subsection{INTRODUCTION}

The Nuclear Waste Policy Act of 1982 (NWPA) provides "... for the establishment of a federally owned and operated system for the interim storage of spent nuclear fuel at one or more ..." federal facilities. Such facilities are currently labeled as Federal Interim Storage (FIS) facilities. The NWPA also states that "the Federal Government has the responsibility to provide ... (1imited) capacity for interim storage of spent nuclear fuel for civilian ... reactors that cannot reasonabiy provide adequate storage capacity (at the) reactors when needed to assure the continued operation of such reactors."

The FIS is intended to be short-term, and is to be discontinued no later than three years after opening of a federal facility for disposal or monitored retrievable storage of these materials. It is currently planned that a federal repository will be in operation by the year 1998, and monitored retrievable storage, if needed, would be in operation by the year 1998 if the repository is delayed. It is currently expected that one or more utilities will need interim storage of spent fuel in the 1984 to 1986 time period (DOE 1983). The Act establishes a 1900-Mg Timit for interim storage. Thus, federal interim storage could be implemented as early as 1985 and emptied and shut down as late as 2001.

Some of the interim storage concepts under consideration involve dry storage of spent fuel in air or in inert gas atmospheres. One of the leading concepts for interim storage is to store spent fuel in large metal storage casks. Current cask designs allow up to 24 PWR fuel assemblies or 52 BWR assemblies (or about double these amounts if the fuel is consolidated and canned) to be placed in each storage cask.

These storage casks may also become licensed for cross-country transportation, but that is not expected to be accomplishable until after 1986. Thus, the spent fuel will be transported in existing casks that are designed and licensed for transportation, and will need to be transferred to the storage casks at the FIS site.

Essentially all of the spent fuel that would qualify for interim storage is in the eastern part of the continental U.S. where large hot cell facilities 
do not exist for transferring the spent fuel from the transportation casks to the storage casks. Transportation cost savings could provide an incentive to build a facility at an eastern site for this intercask transfer. There is also an obvious incentive to construct such a facility in a short time and at low cost. Reverse transfer, i.e. of spent fuel from the storage cask into a transport cask, may also be needed at the end of the interim storage period if the storage casks cannot be used for transportation or if storage cask repair is necessary.

An intercask transfer system may be needed at more than one FIS site if more than one such site is used, or at certain reactors with inadequate cask handling capacity where the utilities may elect to provide their own interim dry storage. The intercask transfer system could also be used at a Monitored Retrieval Storage (MRS) facility for spent fuel and for solidified high-level waste, if an MRS is constructed. Thus, there may he an incentive for an intercask transfer system to be as portable and inexpensive as practicable, to allow for its potential use at more than one facility. This incentive for portability will generally decrease with reduction in capacity required for federal interim storage.

As a result of these incentives, the U.S. Department of Energy (DOE) authorized the Commercial Spent Fuel Management Program Office, operated for the DOE by the Pacific Northwest Laboratory (PNL), to undertake studies of potential concepts for intercask transfer systems. The studies were done to determine the general feasibility of designing and constructing a transfer facility, to identify in general what such facilities might look like, and to determine approximate costs and implementation times. The studies were done between August 1982 and February 1983 by staffs at Kaiser Engineers-Hanford, Raymond Kaiser Engineers-0akland, GA Technologies-San Diego and the PNL. This report summarizes the results of the four concepts considered for these studies. Other concepts could be developed, and any final design of these four concepts could well have significant changes or could combine features from more than one.

The results of these studies are summarized in Section 2. General site requirements, facility functions and functional requirements, and criteria for conceptual design of an intercask transfer system are discussed in Section 3 . 
The four concepts studied are presented individually in Sections 4 through 7 . Appendixes A through $H$ provide supporting data for descriptions of the concepts and for cost estimates found in Sections 4 through 7. 


\section{REFERENCES FOR SECTION 1}

Nuclear Waste Poljcy Act of 1982. Congressional Record - U. S. House of Representatjves, December 20, 1982 , pp. H-10525- $\mathrm{H}-10544$.

U. S. Department of Energy. 1983. Spent Fuel Storage Requirements, DOE/RL-83-1, U. S. Department of Energy, Richland Operations Office, Richland, Washington. 


\subsection{SUMMARY AND CONCLUSIONS}

One or more federal government sites may provide interim storage for spent fuel from commercial nuclear power reactors that have used up all their available storage capacity. Such federal interim storage, if provided, would only be for a short term, on the order of ten years.

One of the leading candidate concepts for this interim dry storage is to place spent fuel in large metal shielding casks containing dry air or inert atmospheres. Spent fuel would be transported in conventional transportation casks in the initial stages of the Federal Interim Storage (FIS) program (the earliest feasible transportation starting time is about 1986 for dry storage). Storage casks may be licensed for transportation in later years of the Federal Interim Storage FIS program. In the case of reactors unable to handle large casks, transportation would always be in conventional transportation casks. Thus, the FIS site would need the capability to transfer the spent fuel from shipping casks to the storage casks, and vice versa, after completion of the storage.

The transfer capability is not readily available at potential preferred eastern federal storage sites. Thus, there may be a need to construct a relatively inexpensive but reliable intercask transfer system for use at an $F$ IS site. In addition, there may be other uses for such an intercask transfer system at other sites (e.g., at selected reactor or fuel reprocessing sites that may implement on-site interim cask storage of spent fuel, or at a fuel reprocessing plant that may be used as a Monitored Retrievable Storage (MRS) site for cask storage of solidified and canistered high-level waste). Thus, there may be an advantage in having an intercask transfer system that is largely portable for reuse at other sites.

Based on these considerations, the Department of Energy commissioned its Commercia? Spent Fuel Management Program Office, operated by the Pacific Northwest Laboratory, to carry out a brief pre-conceptual study on the feasibility of several potential low-cost intercask transfer systems that would satisfy the needs described above. These studies were carried out by staff at Kaiser Engineers-Hanford, at Raymond Kaiser Engineers-0akland, at GA Technologies-San Diego, and at the Pacific Northwest Laboratory-Richland, between August 1982 and February 1983. 


\subsection{SUMMARY}

A host site for federal interim storage (and the intercask transfer system) is assumed to provide the required utility services, the roadway capability to receive large shipping casks by the truck and rail transport modes, genera 1 administrative and security services, and 0.6 to 3 hectares of land for an intercask transfer system, if used.

The transfer systems were conceived to handle the transportation casks designated as NLI $1 / 2$ (or NFS 4), NLI 10/24, TN8/TN9, and GE IF300; and the storage casks designated as REA 2023 and GNS Castor $V$.

Four concepts were conceived, all of which include a large crane for lifting the casks, a transfer car for moving the storage casks to their on-site storage positions, and an outer building to help control potential contamination. To aid in portability, all of the concepts to some degree use separate trailers to house auxiliary needs (i.e., exhaust ventilation treatment, personnel change room, operating control room, and chemical handling of decontamination solutions). The four concepts, in decreasing order of portability, are:

- Turntable. This concept consists of a large lifting crane and a largediameter, shielded cylinder in a prefabricated metal building. The base of the cylinder is a large rotating turntable on which a transport and a storage cask are set. Transfers of spent fuel or canisters between casks are made by alternately rotating the turntable so the transport cask is under the lifting mechanism and a fuel assembly or canister can be removed, then rotating so that the receiving cask is in position to receive the fuel assembly as the lifting mechanism is lowered. (See Figure 4.1 in Section 4. )

- Shuttle. This concept consists of a shielded fuel handling machine mounted on a bridge-like structure. The bridge allows shipping and storage casks in a vertical position, each on its individual transfer car, to be shuttled into position under the fuel handling machine. Adapters allow mating of the cask openings to the bottom of the fuel handing machine. Spent fuel is lifted from the shipping cask; the shipping cask is then 
moved back and the storage cask is moved into position to receive the fluel assembly or canister from the fuel handling machine. The fuel handling and shutt pe systems are located inside a prefabricated metal building. (See Figure 5.1 in Section 5.)

- Trench. This concept consists of a small hot cell (càlled fuel transfer room) that is made of prefabricated stacking concrete sections and that extends from a trench to above grade. Inside the metal building that houses the fuel transfer system, a large bridge crane places the two types of casks vertically onto individual transfer cars located in a short, concrete-lined trench. The transfer cars, which are integral with part of the hot cell shielding walls, move the casks into the fuel transfer room where the intercask transfer is accomplished by manipulators and in-cell cranes. (See Figure 6.1 in Section 6.)

- Igloo. This concept includes a large, rectangular hot cell (called fuel transfer chamber), made of an oval-shaped corrugated steel metal liner shielded by an earthen berm. The two types of casks are placed vertically on a single transfer car by an outside crane. The transfer car moves the two casks into the fuel transfer chamber (through an airlock chamber that is an extension of the fuel transfer chamber). Spent fuel is transferred by alternately moving the transfer car to orient the two casks to their position under a fuel transfer tower. The fuel transfer tower, similar to that in the turntable concept, extends to above the earthen berm. (See Figure 7.1 in Section 7.)

Overall characteristics of the four concepts are summarized in Table 2.1. The first six characteristics in Table 2.1 were alluder to in the descriptions above. Cask decontamination locations include in-pit, in-place and in a decontamination cell. Spent fuel decontamination and possible recanning or repair capabilities vary from essentially none in the turntable and shuttle concepts to some in the trench and igloo concepts. All concepts have calculated transfer capacities equal to or greater than the $400 \mathrm{MgHM} / \mathrm{yr}$ criterion set for this study. The capacity of the turntable concept, however, is based on having two transport casks in the system at one time. The operating staff required for all concepts is estimated to be about 29 to 33 . 


\section{TABLE 2.1. Summary of General Characteristics of the Intercask Transfer Concepts}

\begin{tabular}{|c|c|c|c|c|c|}
\hline & Characteristic & Turntable & Shuttle & Irench. & 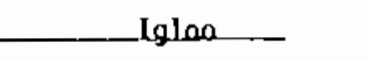 \\
\hline 1. & $\begin{array}{l}\text { Cask lifting inside or outside } \\
\text { of outer building }\end{array}$ & Inside & Outside & Inside & Outside \\
\hline 2. & Transfer cars used for casks & No & Yes & Yes & Yes \\
\hline 3. & Hot cell & None & None & Smal 1 & Large \\
\hline 4. & Major gamana shielding & Steel/lead & Steel & Concrete & Earthen berm \\
\hline $\begin{array}{l}5 . \\
6 .\end{array}$ & $\begin{array}{l}\text { Operating technique } \\
\text { Viewing }\end{array}$ & $\begin{array}{l}\text { Automated machinery } \\
\qquad \operatorname{CCTV}^{(a)}\end{array}$ & $\begin{array}{l}\text { Automated machinery } \\
\operatorname{ccTV}^{(a)}\end{array}$ & $\begin{array}{l}\text { Hot cell } \\
\text { Windows/CC }\end{array}$ & $\begin{array}{l}\text { Hot cell \& automation } \\
\text { TV }^{(a)} \operatorname{cCTV}(a)\end{array}$ \\
\hline 7 & Cask decontamination location & $\ln p i t$ & In place & In pit & In decon. cell \\
\hline 8. & Spent fuel decontamination capability & none & uNone & Yes & Yes \\
\hline 9. & Recanning/can repair capability & ఒone & vone & Possible & Possible \\
\hline 10 & Uperating capacity, MTU/yr ${ }^{(b)}$ & $<540^{(c)}$ & $>525$ & 435 & $>480$ \\
\hline 11. & Nunber of full-tine operating staff & 33 & 30 & 29 & 29 \\
\hline 12. & $\begin{array}{l}\text { \% of capital costs that are for a non- } \\
\text { transportable portion of the facility }\end{array}$ & 1.9 & 2.6 & 7.6 & 28.9 \\
\hline 13. & Implementation time, months $\{\mathrm{e}\}$ & 41 & 24 & 24 & 18 \\
\hline 14. & Relocation tillie, months & 10 & 14 & 14 & 14 \\
\hline 15 & Developnent required & Yes & Some & No & No \\
\hline
\end{tabular}

(a) CCTV = closed circuit television

(b) For unconsolidated spent fuel received $50 \%$ by truck and $50 \%$ by rail, facility operating 250 days/year, 24 hours/day; other bases believed to be conservative

(c) Based on 2 transport casks in the system (one being unloaded; the other in preparation) at one time. For one transport cask at one time, the capacity is $\sim 390$.

(d) Based on capital costs exclusive of design and development costs.

(e) From start of design and development--assuming licensing by the NRC is not required. 
Capital costs (discussed below) for nontransportable parts of the facility are estimated to be the lowest for the turntable and shuttle concepts at $1.9 \%$ and $2.6 \%$, respectively; somewhat higher for the trench concept at $7.6 \%$, and the highest for the igloo concept at $29 \%$. The implementation time is estimated to be relatively long for the turntable concept, about 41 months, because of the new design/development and special fabrication needs. Implementation times for the shuttle and trench concepts are about 24 months each; for the igloo concept only about 18 months because of simpler design and construction. Time for shutdown, dismantling, transport to a new site, reassembly and shake-down tests is estimated at ten months for the turntable and 14 months for the other three concepts. About six months' time and effort is believed to be necessary for development and conceptual design of the turntable concept, and some effort may be necessary for the shuttle concept because of the relatively nonstandard design of these concepts. The other concepts should require essentially no conceptual design.

High-spot cost estimates are shown in Table 2.2 for the four concepts. Design and engineering costs range from $\$ 1.2$ million to $\$ 2.2$ milition, with the higher costs for the more readily transportable concepts. The capital costs for these concepts are also higher at $\$ 9.1$ to $\$ 11$ million compared to about $\$ 8$ million for the trench and igloo concepts. Operating costs are about equal for each concept at about $\$ 2$ million/year. Relocation costs are about $\$ 1$ million for the more readily transportable concepts to $\$ 2.7$ million for the igloo concept (which reflects new construction needed at the second site). Transportation costs for relocation were not estimated for any concept.

\subsection{CONCLUSIONS}

From the results of this study, the following overall conclusions are drawn:

- A variety of concepts may be used as a minimum-investment dry intercask transfer facility for spent fuel or canisters, with a spent fuel transfer capacity of 400 to $500 \mathrm{MTU} / \mathrm{yr}$. Higher capacities may require further study.

- Total design and capital costs are in the range of $\$ 9$ to $\$ 13$ million at a host federal site. This is relatively inexpensive compared to costs for most current concepts of hot cells. 
TABLE 2.2. Summary of Costs of Intercask Transfer Concepts

\begin{tabular}{|c|c|c|c|c|}
\hline \multirow[b]{2}{*}{ Cost Item } & \multicolumn{4}{|c|}{ Costs for Concept ${ }^{(\mathrm{a})}$} \\
\hline & Turntable & Shuttle & Trench & Igloo \\
\hline Design and Engineering, $M \$$ & 2.2 & 1.5 & 1.2 & 1.2 \\
\hline Capital, $M \$(b)$ & 11.0 & 9.1 & 8.1 & 7.6 \\
\hline Operating, $M \$ / y r(c)$ & 2.3 & 2.1 & 2.0 & 2.0 \\
\hline Relocation, $M \$(d)$ & 1.1 & 1.0 & 1.6 & 2.7 \\
\hline
\end{tabular}

(a) All costs are in 1982 dollars and include 30\% contingency.

(b) Capital costs include those for a 100-Mg crane for cask handling and an on-site transporter vehicle for the storage cask; costs do not include host site costs for bringing utilities, fencing, roads to the facility.

(c) Based on operating at $400 \mathrm{MTU} / \mathrm{yr}$ of unconsolidated spent fuel transferred/year.

(d) Include costs of shut-down and dismantling at the first site, reassembly and shakedown tests plus new capital costs at the second site. Transport costs are not included. 
- An intercask transfer system can be designed with as 1ittle as $2 \%$ of the construction costs required for nonportable construction. However, portability adds $\$ 2$ to $\$ 4$ million to the capital costs of the more conventional hot cell type of systems (which have $8 \%$ to $30 \%$ of the construction costs for nonportable construction).

- Implementation times of conventional hot-cell type systems are in the range of 18 to 24 months. More complex systems with highly automated machinery may require up to about 40 months because of the special development/design and fabrication requirements.

- If implementation of dry storage at a federal site is needed in 1986 , development/design of an advanced intercask transfer system such as the turntable must start immediately (by mid-1983) and be expedited. For most other concepts, a lead time of about 24 months from the signing of a contract is required to design and construct.

- Sufficient information has been developed in this study to provide the bases for initiation of optimizing design efforts.

- Operating costs are approximately $\$ 2$ million/year for all concepts.

- Relocation costs for the transfer system are about $\$ 1$ miliion plus the costs of new construction at the second site (up to $\$ 1.7$ miliion for one hot cell type of concept studied here), plus shipping costs.

- Relocation times for the transfer system are in the range of 10 to 14 months for all concepts studied.

- The more conventional hot cell type of systems offer more flexibility for abnormal activities such as repairing or recanning the spent fuel or canisters, or performing decontamination of the containers of high-level materials, than do the more compact and automated systems.

- The incentives for implementing a minimum-investment type of intercask transfer facility at a given site should be determined by comparing the costs/benefits of such a systen with those of an FIS site with equal or better facilities. Such comparisons should also include transportation differences for the spent fuel or canisters at the two potential storage sites.

- The potential advantage of maximum portability of an intercask transfer system must be weighed against its higher cost and lower operational flexibility.

\section{7}


If plans for implementation of systems discussed in this study become serious, cost/benefit studies (as mentioned above) should be carried out in concert with evaluation of potential sites for one or more FIS facilities to determine the incentives for a minimum-investment type of intercask transfer capability. In addition, more detailed concept design studies could be undertaken to identify a more optimized system than those conceived in this study. 


\subsection{REQUIREMENTS AND CRITERIA}

As stated in Section 1.0, the primary intended use of an intercask transfer system is to transfer spent fuel (inside of or without canisters) in air between licensed transportation casks and metal storage casks at a Federal Interim Storage (FIS) site. The studies documented in this report are aimed at this primary use, with allowance for flexibility for other uses. Additional uses could be at civilian nuclear reactors to support spent fuel storage or at other federal facilities for storage of spent fuel and/or solidified high-level wastes. If or when storage casks become licensed for cross-country transport, the use of an intercask system would likely not be needed; but if needed, it would be limited to spent fuel or solidified high-level wastes at reactors or storage facilities that do not have the capabilities to handle the large railcarried storage casks.

The overall function of the transfer equipment system would be to provide for safe and effective transfer of intact spent fuel assemblies or canisters lof spent fuel as assemblies or consolidated, or of solidified high-level waste) between transport and storage casks.

After interim storage, the transfer would be in the other direction, i.e., from the storage cask to the transport casks for shipping of the cargo to its next designation (i.e., a Monitored Retrievable Storage facility, a fuel reprocessing facility, or a waste disposal repository).

From this basic purpose, the general site requirements, facility functions and functional requirements, and criteria for conceptual design were developed as identified in the subsequent sections.

\subsection{CAPABILITIES AT THE HOST SITE}

The transfer equipment studied in this report, if implemented, is expected to be installed at one or more existing federal sites and operated by DOE contractor(s). The precise sites are not yet defined, but for the purpose of this study, a candidate federal site is assumed to have the capabilities discussed below. 
A site will have capabilities to accept casks on trucks or railcars. Truck roads and rail tracks will be provided to the intercask transfer system. A site will have existing roads to move the storage casks on-site to their storage locations. A site will have sufficient space for this facility. nperation of this facility should not interfere unduly with other operations at the site.

A staff will be provided by the DOE contractor for operating and maintaining the intercask transfer equipment and the buildings and services utilized. It is assumed that the contractor has a major DoE contract at the site, and only modest incremental administrative, security, and other staff are needed to support this activity.

Services provided at the federal site will include conventional utility services such as electricity (alternating current in 480- and 240-volt 1-phase and 3-phase, and 120-volt 1 phase) and emergency electrical power, electric lighting, deionized or distilled water under pressure, clean compressed air at approximately 9.2 atmospheres (100 psig) and at lower pressure if needed, steam at about 9.2 atmospsheres, process and sanitary sewage and sanitary facilities for the staff, fire and security protection and alarms, telephone communications, and heating and air conditioning.

Fxisting buildings or structures (e.g., concrete pads) are assumed to be unavailable in this study. Other hardware, such as an overhead crane for lifting or short movements of transport and storage casks are also assumed to be unavaliable for this facility at the site.

\subsection{BASIC FUNCTIONS}

The basic operationa? functions of the intercask transfer equipment are to:

1. receive, position and discharge shipping and storage casks

2. remove, temporarily store and reinstall cask closures

3. handle and transfer spent fuel assemblies as assemblies or in canisters (or canistered comercial $\mathrm{HL} \mathrm{W}^{\mathrm{i}}$ ) from one cask to another. 


\subsection{FUNCTIONAL REQUIREMENTS}

The basic functional requirements of the intercask transfer equipment are to provide:

1. radiological protection of personnel, the public and equipment

2. heat removal capability

3. radiological monitoring systems

4. material accountability

5. shipping and storage casks seal replacement.

6. normal industrial protection for personne?

\subsection{DESIGN CRITERIA}

Draft design criteria were initially developed by PNL staff. These were modified as a result of reviews by Kaiser Engineers-Hanford and GA Technologies. The resultant design criteria for the intercask transfer equipment are listed below, and explanation of the bases for some of the criteria follow this listing.

1. The facility is to provide the maximum transfer capacity of $400 \mathrm{Mg}$ of heavy metal (MgHM) per year or equivalent in high-level waste.

2. The facility is to be capable of operating on three shifts per day for 250 days per year, if required.

3. The facility equipment is to be compatible with the following shipping casks: TN8/TN9, NLI 1/2 (NFS4), NLI 10/24, and GE IF300. (See Apendix A.)

4. The facility equipment is to be compatible with the following storage casks: REA 2023 and GNS Castor V. (See Appendix B.)

5. To the maximum extent practicable the facility/equipment is to be readily disassembled for overland shipment to other sites.

6. The maximum dose rates to the exterior surface of facility hardware in restricted areas are to be the same as the regulatory limit for transport vehicles, or $200 \mathrm{mR} / \mathrm{hr}$ (NRC 1983). The maximum dose rate in normally occupied areas is to be $0.5 \mathrm{mR} / \mathrm{hr}$ (DOE 1981). 
7. The heat removal capability is to be adequate to limit the maximum spent fuel cladding temperature to $250^{\circ} \mathrm{C}$ and to limit the maximum commercial $\mathrm{HLW}$ canister temperature to $375^{\circ} \mathrm{C}$. It is possible that at the spent fuel cladding temperature of $250^{\circ} \mathrm{C}$, an inert gas atmosphere may be required. If, at the final calculated temperature, inert gas is required, provisions would be needed to allow introduction of inert gas into the storage cask. (See Appendices $C$ and $D$ for reference spent fuel and HLW characteristics.)

8. The facility is to be capable of operation at existing federal sites.

9. The transfer equipment is to be designed to minimize the spread and extent of radioactive contamination of cask and transfer equipment surfaces. This requires containment of the spent fuel as well as confinement and appropriate treatment of the atmospheres in the cask and in the transfer chamber.

10. Facility and equipment are to be designed, to the extent practicable, to facilitate the decontamination required for operation, site-to-site transportation, erection, disassembly, and final disposal.

11. A minimal decontamination system is to be provided for routine cleanup of shipping and storage casks.

12. The design of transfer equipment is to provide for good operating reliability and availability.

13. The facility should preferably satisfy applicable regulations and be licensable.

14. The transfer equipment is to be designed to prevent damage to spent fuel and/or commercial HLW and their canisters during handling.

15. The transfer equipment design is to provide for recoverability in the event of equipment or system malfunction.

16. The transfer equipment design is to provide capability for continuous monitoring of spent fuel or canister positions.

17. The transfer equipment design is to provide the capability for visual inspection of spent fuel or canisters. 
18. The transfer equipment design is to provide for operation by trained personnel of average capabilities, and for routine maintenance by trained personnel with a minimum of highly specialized equipment.

19. The transfer equipment is to be capable of operating by using standard services such as electrical power, compressed air, steam and water. Comments or explanations of some of the design criteria are discussed below:

Criterion 1. The handling capacity was established in August 1982 when it appeared that the maximum storage capacity of an FIS would be no more than 1200 MTHM and should be capable of being emptied in three years. The Nuclear Waste Policy Act allows for an Fis up to $1900 \mathrm{MgHM}$, also capable of being emptied in three years. This potential handling capacity would be $58 \%$ higher than that specified. Before an intercask transfer system is implemented, an evaluation should be performed to determine the best estimate of its needed capacity. It is highly possible that $400 \mathrm{MTHM} / \mathrm{yr}$ will be a reasonable capacity for the largest FIS to be implemented. The analyses in this report are based on the handling rate of spent fuel assemblies. For consolidated spent fuel and high-level wastes, the handling rates would be factors of about 2 and 5 higher, respectively. Criterion 2. The number of operating days/year is based on 50 weeks/year and 5 days/week. This allows for $40 \%$ extra capacity on the weekends if necessary. Around-the-clock operation is believed to be appropriate for the large number of casks to be handled, and is not uncommon at most DOE sites.

riterion 3. The listing of transport casks covers essentially all those currently available in the U.S. It is believed that the facility should be able to accommodate all of these. Furthermore, if the facility can handle all of these, it should be capable of handling most other types that may be available during the time period of concern.

Criterion 4. The two designated storage casks are those currently being considered in DOE's development program. If the facility can handle these casks, it should be capable of handling most other types that may be available during the time period of concern. 
Criterion 5. The portability of the intercask transfer equipment is important in providing flexibility for the DOE to disassemble and re-use the equipment at other sites. However, it may be difficult to design those items of great mass and bulk, e.g., the hot cell structures and shielding, to be both readily transportable and economical in cost. If the transfer system utilizes expendable shielding, such as water or earth, the expendable shielding would be excluded from the transportability requirements. The value of portability in the final analysis, however, will depend on its total costs and benefits, and will require some analysis of these factors.

Criterion 6. The $200 \mathrm{mR} / \mathrm{hr}$ value is based, as stated, on the allowable regulatory dose rate for the external surface of transportation casks, and that seems reasonable here for areas that are restricted and do not require continuous occupancy. The $0.5 \mathrm{mR} / \mathrm{hr}$ is based on DOE's operating limits in unrestricted areas of $1000 \mathrm{mR} / \mathrm{yr}$ to personnel. It applies to all areas that would be continuously occupied by operating personnel, such as control rooms, certain operating areas, etc.

Criterion 7. The $250^{\circ} \mathrm{C}$ limit for spent fuel cladding is based on currently expected limits for dry storage of spent fuel. (Rasmussen et a1. 1982). In the event that an inert gas atmosphere would be required for the final design limit of allowable spent fuel temperature, additional provisions would be needed to add and control the inert gas to the storage cask. The $375^{\circ} \mathrm{C}$ limit for high-level waste canisters will limit the temperature of high-level waste to that which should cause no significant physical changes in borosilicate glass that incorporates HLW (Slate et a1. 1981).

Criterion 13. The Nuclear Waste Policy Act does not specifically state that an Fis at a federal site requires licensing, but it is believed that design of an intercask transfer system that is licensable will provide for good operational safety.

Criteria 16 and 17. These capabilities may not necessarily be needed continuously, at least in all concepts. However, it is believed that the 
capability will be used to a significant extent. In some concepts, (e.g., the shuttle and turntable concepts), the desirability of these criteria is very high.

From all requirements, functions and criteria in this section, four intercask transfer systems were conceived. Sections 4 through 7 present the information available on these concepts. The concepts were developed only to the extent of identifying major features and allowing for high-spot estimates of design, construction, and nperating costs and implementation times. These four concepts are not intended to encompass all major types of such facilities. Furthermore, important changes would be expected in a final design of any of these concepts.

The level of detail developed for the various concepts is not the same for all concepts. However, sufficient information is available for all concepts to accomplish the objectives of this study. 


\section{REFERENCES FOR SECTION 3}

Rasmussen, D.E. et al. 1982. Comparison of Cask and Drywell Storage Concepts for a Monitored Retrievable Storage/Interim Storage System. PNL-4450, Pacific Northwest Laboratory, Richland, Washington.

Slate, S.C. et al. 1981. Reference Commercial High-Level Waste Glass and Canister Definition, PNL-3838, Pacific Northwest Laboratory, Richland, Washington.

U.S. Nuclear Regulatory Commission. 1983. Code of Federal Regulations, Title 10, Energy, Part 71, "Packaging of Radioactive Material for Transport and Transportation of Radioactive Material Under Certain Conditions, "Revised January 1, 1983, U.S. NRC, Washington, D.C.

U.S. Department of Energy. 1981. Environmental Protection, Safety, and Health Protection Program for DOE Operations, U.S. DOE Order 5480.1 Chapter XI, Change 6. U.S. Department of Energy, Washington, D.C. 


\subsection{TURNTABLE CONCEPT}

The turntable concept for an intercask transfer system was conceived by the staff at PNL. Specific criteria were to emphasize portability of the system and to minimize site support facility. Conceptualizing of this system was extremely cursory, and received the least effort of the four concepts. The information presented here is based largely on that work, with some amplification by Reynolds (1982) and Griffen and Spritzer (1983). Additional analysis by the author is based on that of Griffen and Spritzer.

\subsection{DESCRIPTION}

The turntable concept, shown in Figure 4.1 , consists primarily of an integral, compact, metal-shielded structure within which the casks are placed. Transfer of spent fuel or canisters is done within the structure using several semi-automatic mechanisms. The turntable is located inside a portable prefabricated metal building that can receive and dispatch large metal storage casks, and transport casks shipped by truck or rail. The casks are handled by a large bridge crane within the building. After the storage cask is full of spent fuel or canisters, it is sealed within the turntable equipment, lifted onto the on-site transporter that moves it from the building to an aboveground storage area. Empty transport casks are removed from the turntable equipment, lifted onto cross-country vehicles that moved them from the building to their off-site designation.

\section{$4.1 .1 \underline{\text { Site }}$}

The overall site requirements would be similar to almost any other small, fixed nuclear fuel cycle facility at grade level. Site area needs include those for the main building, the portable ventilation annex building, the trailers used as change rooms, a decontamination equipment room, and an allowance for outside parking of casks. The estimated size of the prefabricated building that would meet the requirements of this concept is approximately $13.7 \mathrm{~m} \times 30.5 \mathrm{~m}(45 \mathrm{ft} \times 100 \mathrm{ft})$. The estimated minimal area needed is on the order of $125 \mathrm{~m} \times 55 \mathrm{~m}$ (assumed to be approximately 4 times the dimensions of the major building), or about 0.7 hectare. The site is assumed to be part of a host site that. will provide services such as administration, security, and health physics and utilities such as electrical power, water, and steam. 



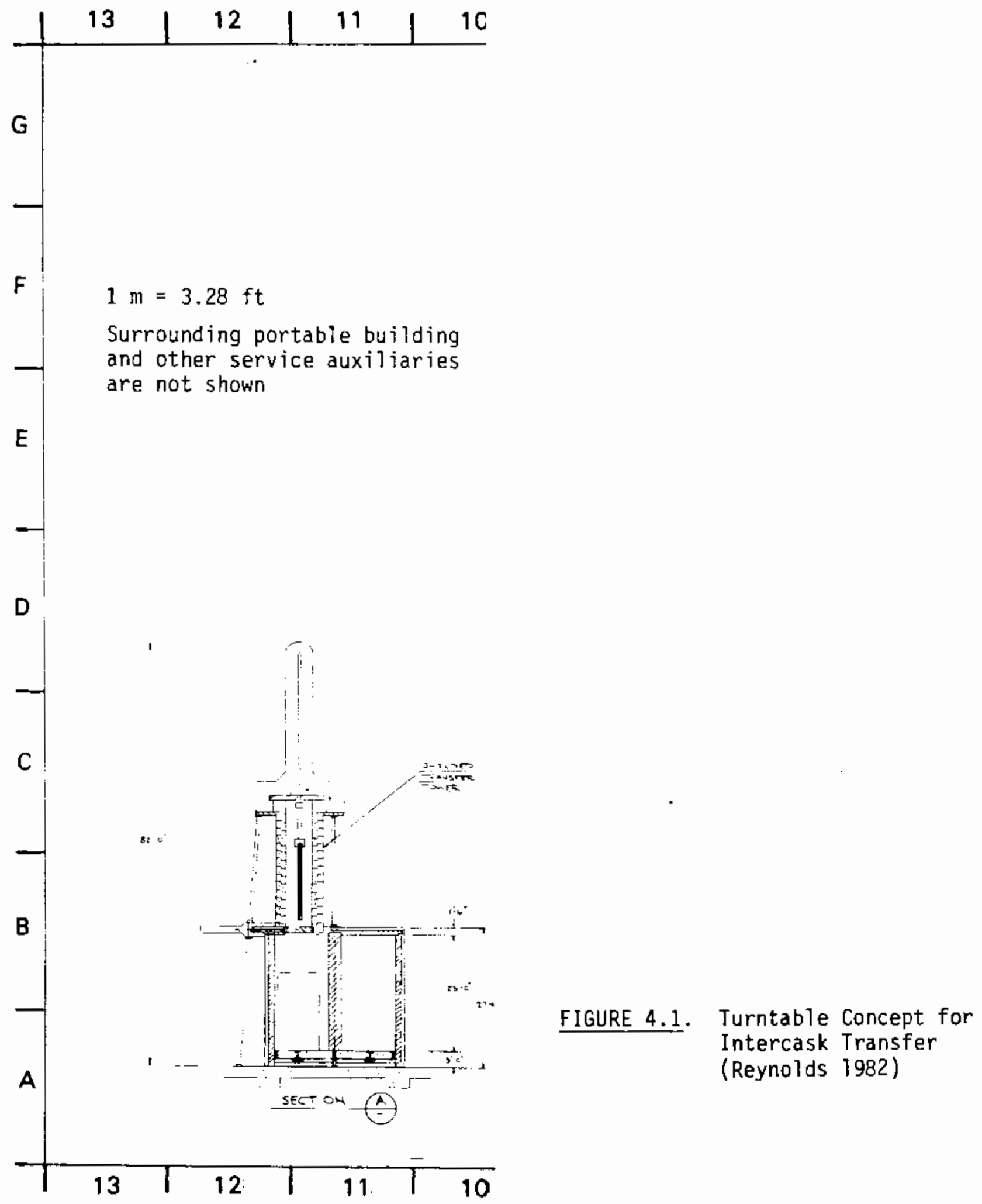


• 
The facility must be accessible by both rail and truck to receive the shipping and storage casks. An additional rail spur to the storage cask parking area is atso provided.

\subsubsection{Outer Enclosure}

The 15.2-m-high main building is assumed to be a prefabricated and portable meta? building with special sealing at joints and penetrations, and sufficient structural members to support the large cranes and casks. The turntable is located in one corner of the building with the fuel handing tower extending through the roof of the building. The main building provides weather protection for the transfer operations, and provides a second level of confinement against potential releases of radioactive materials.

A concrete floor provides a foundation for the prefabricated building. Additional slabs for the portable support facilities are also required. Recessed rails are provided in the floor for the shipping cask and the storage cask vehicles, and for the on-site storage cask transporters. A small concretelined pit is provided in the building floor for cask decontamination.

\subsubsection{Cask and Fuel Handling}

Cask handling and positioning is done inside the outer enclosure building. Spent fuel or waste handling and cask lid removal/installation are done inside the shielded turntable.

Cask Handling

Casks are brought into the main building on their over-the-road or on-site transport vehicle. Inside the building, the casks are lifted from their vehicles by a $100 \mathrm{Mg}$-capacity bridge crane that spans most of the area of the building, then placed vertically on the open segment of the turntable. The outer cask lids (if any) are removed and inner cover bolts are removed. The turntable is then rotated to its appropriate position, the turntable shielding door is closed, and the final 1 id and fuel handling is accomplished using the mechanisms within the turntable.

Removal of the transport cask is done in the same manner in the reverse direction. Removal of the storage cask is accomplished in the same way. The cask is then placed on the on-site storage cask transporter that takes it from the facility to the FIS area. 


\section{Turntable}

The large capacity turntable is enclosed and shielded with three chambers that supply the cask heads and fuel element lifting capabilities. The turntable rests flat on the concrete floor of the main building, and rotates using electric, hydraulic or pneumatic equipment. The fixed-position sides are constructed in the shape of a cylinder with a quarter-section removed. One side of the removed quarter section is fixed and rigid, the other side has a hinged shielding door used for access to the interior. The sides are constructed of steel and are used for containment and structural strength. The sides and top are provided with about $30 \mathrm{~cm}$ of steel equivalent for gamma shielding and about a $15-\mathrm{cm}$ water jacket for neutron shielding. (This shielding may be thinner near the bottom.)

Above the turntable are three lifting ports. The two short ports are provided to lift the inner lids of the casks and secure them in such a manner that they will not collide with the casks rotating on the turntable below. To facilitate automatic attachment to the lifting grapples in the lid-lifting ports, a lifting attachment is bolted to the cask lid before a cask is placed into the transfer machine. The third and tallest port, the fuel handing tower, is the fuel assembly lifting port. This is a hollow, shielded cylinder equipped with a 1 ifting device capable of $X, Y, Z$ and rotational direction movement. The transfer tower shielding is made of stacked "donuts" of prefabricated concrete supported by a rigid steel structure that rests on the turntable base. Alternatively, it may be composed of steel and a water jacket. The hoist mechanism operates through structural shielding at the top opening of the tower. A shielding and sealed door is provided at the bottom of the transfer tower port. This allows for a fuel assembly to be lifted up into the port, the door closed, and the port and fuel element removed from the transfer equipment during abnormal conditions. Drive mechanisms for the lifting devices are outside the shielding to facilitate their repair in-place or removal for repair, if required. Most mechanisms can be operated manually if necessary. Alignment sensors and remotely operated optics systems are placed as needed within the ports and transfer chamber. The total turntable assembly is estimated to weigh about $1000 \mathrm{Mg}$. The turntable is constructed of large pieces that can be disassembled, transported to another site, and reassembled for re-use. 


\section{Fuel Handling}

After both casks are in their respective positions inside the turntable, the lifting mechanism is oriented above the transport cask. The lifting mechanism grasps a fuel assembly or canister and lifts it up into the tower. The turntable is rotated so that the receiving cask is under the tower, and the 1 ifting mechanism lowers and deposits the fuel assembly or canister. The procedure is repeated until the cask being emptied is empty or the receiving cask is full. The inner lids of the respective casks are then placed in position on the casks, and the casks are removed from the turntable for completion of their preparations and loading onto their respective transport vehicles.

No capability is provided inside the turntable system for repairing or recanning spent fuel or canisters.

\section{1 .4 Viewing}

Operation of the activities within the turntable assembly is done remotely, by staff at a control console near the assembly. The mechanisms are automated and give continuous read-out of positions. Viewing is used as an assist to this normal operation and as a key part of abnormal operations.

Viewing inside the turntable system is accomplished through the use of closed-circuit television. Television cameras are located in the large cask chamber, in the fuel lid handling chamber, and in the transfer tower. The television cameras have pan, tilt and zoom capability. Specific lighting is provided for each of the cameras inside the mechanism.

\subsubsection{Ventilation}

The ventilation for the turntable building is of conventional design with the flow of filtered and conditioned air into the operating area from the air conditioning system located on the roof. The pressure in the building is maintained slightly negative relative to atmospheric pressure by an exhaust located in the adjacent fanffilter room. Before discharge to the atmosphere through the exhaust stack, all air is filtered through High Efficiency Particulate Air (HEPA) filters, located in the adjacent fan/filter room. 
Some of the building supply air flows directly into inlet ventilation ports in the turntable system. The air from the turntable is exhausted from other ports and routed directly to the fan/filter room for HEPA filtration before discharge out the stack. An auxiliary system operates to exhaust more air when the turntable door is open. A greater negative pressure is maintained within the turntable mechanism to assure flow of air from the operating area to the turntable.

Sufficient ventilation air, supplied inside and outside of the turntable, removes decay heat of the spent fuel or high-level waste.

\subsubsection{Decontamination and Contamination Control}

Decontamination and limited repair of the casks can be accomplished in the decontamination pit. Decontamination solutions are pumped from a trailer outside the building to the decontamination pit and are returned via a sump to the trailer for filtration and recycle. Essentially no decontamination of the spent fuel or canisters can be done using the turntable system. Decontamination of the turntable is done by personnel contact cleaning while the turntable is empty. General contamination control is accomplished using conventional operating practices such as using plastic aprons over the casks while they are inside the turntable. A clothing change room for operating staff is located in a trailer adjacent to the main building.

Radiation monitoring equipment in the facility provides continuous surveillance of radioactivity levels in a11 areas inhabitable by personnel. Radiation probes within the turntable provide a continuous measure of the shield interior. Audiovisual alarms are activated when specified exposure rates are exceeded. The exhaust gases at the stack are also continuousiy monitored. 


\subsection{OPERATING SEOUENCES}

The normal operational sequences for intercask transfer of spent fuel or canisters using the turntable concept are listed in Table 4.1. A pictorial summary of the turntable manipulations is given in Figure 4.2 .

\subsection{SYSTEM CAPACITY}

The major operational steps required to receive, handle, unload and dispatch a truck cask and a rail cask are shown in Table 4.2. For each major operational step, information is provided on the procedure, the number of personnel involved, the time required for each step, and the elapsed time. The time requirements are conservatively based on information for in-pool transfers by Baer (1982). The information presented in Table 4.2 shows cask turnaround times of about 21 and 31 hours for truck and rail shipping casks, respectively. These turnaround times are used to estimate capacity here.

Further studies of wet shipping cask handling times were reported by McCreary (1981). A larger crew of skilled operators performed repeated runs with a TN-9 cask (a large truck cask) to build proficiency, to refine techniques, and to use certain special equipment. A cask turnaround time of approximately 12 hours was achieved. Additionaliy, Franklin (1981) reported enhanced cask turnaround for truck and rail casks of about. 8 and 30 hours, respectively.

These studies show that the capacities estimated here should be conservative, especially for the dry transfer systems in this study. Such conservation should tend to compensate for the negligible allowances here for extraordinary decontamination and maintenance.

For each 12 truck casks containing two PWR fuel assemblies 10.461 MTU/assembly), one storage cask containing 24 PWR assemblies must be handled. This storage cask handling requires eight hours additional time for each 166 hours of truck shipping cask handling time. Thus, the total time requirements for 12 truck casks is $166+8=174$ working hours. This translates to 1.53 MTU/day or 131 days for 200 MTU. Note that this assumes that 2 truck shipping casks can be in the cycle at one time. To do this requires good scheduling of activities. Realistic long-term routing capacity may be lower than this. 
TABLE 4.1. Operational Sequences in the Turntable Concept

\section{Shipping or Storage Cask Preparation}

1. Receive cask from shipping and receiving area. Perform necessary monitoring, checking, and paper work.

2. Lower cask onto cask set-down pad and secure.

3. Remove outer cover and store.

4. Remove inner cover attachments and store.

5. Place and secure lifting attachment for inner cover.

6. Install "bib" around cask.

\section{Loading the Turntable}

1. Open shielding door on turntable.

2. Fasten support fixture to the turntable.

3. Lift storage cask onto support fixture.

4. Place attachment on storage casi Tid.

5. Loosen fasteners on storage cask lid.

6. Rotate turntable $90^{\circ}$ clockwise.

7. Repeat steps 2 through 5 for transportation cask.

8. Rotate turntable $155^{\circ}$ clockwise.

9. Close and secure shielding door.

\section{Fue 1 Transfer "}

I. Remove storage cask lid in last position above.

2. Rotate turntable $90^{\circ}$ counterclockwise.

3. Remove transportation cask lid.

4. Rotate turntable $90^{\circ}$ clockwise.

5. Remotely grasp a fuel element and lift it into the transfer tower.

6 . Rotate turntable $90^{\circ}$ counterclockwise.

7. Lower fuel element into storage cask.

8. Repeat steps 4 through 7 untif transportation cask is empty.

Un loading the Turntable

1. Replace lid on transportation cask.

2. Rotate turntable $90^{\circ}$ clockwise.

3. Replace lid on storage cask.

4. Open shielding door (after monitoring the instruments).

5. Rotate turntable $155^{\circ}$ counterclockwise.

6. Decontaminate storage cask and fixtures.

7. Remove lid lifting attachment.

8. Secure lid.

9. Lift off storage cask and place on cask set-down pad.

10. Remove support fixture.

11. Rotate turntable $90^{\circ}$ counterclockwise.

12. Repeat steps 6 through 10 for the transportation cask.

13. Decontaminate enclosure.

14. Close door.

\section{Preparation for Cask Return}

L. Replace inner cover attachments and secure.

2. Inspect for contamination.

3. Move cask to decontamination pit, if required.

4. Decontaminate and reinspect.

5. Move cask to shipping and receiving area and onto vehicte.

6. Perform necessary tie dom, check-out, and paper work. 

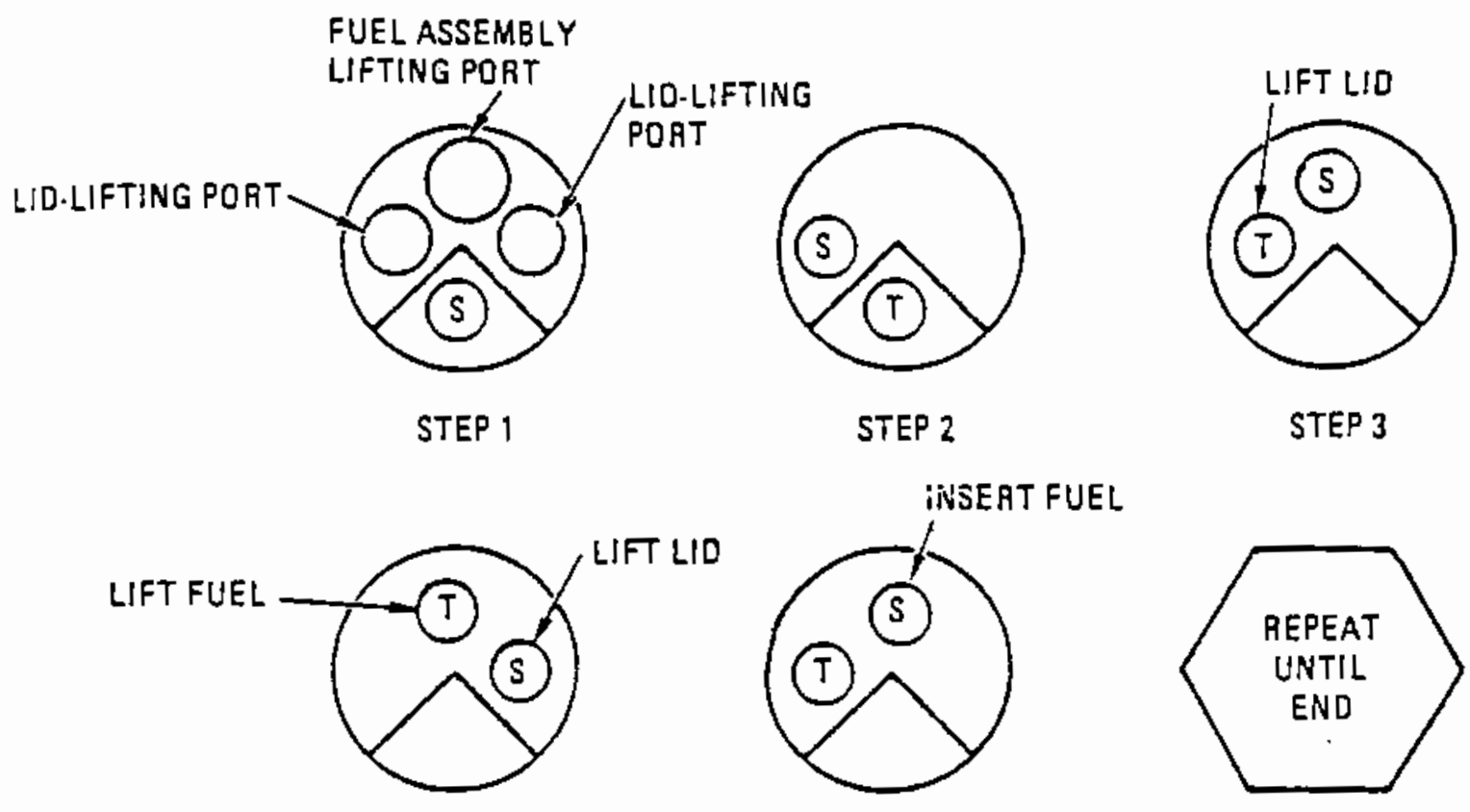

STEP 4

STEP 5

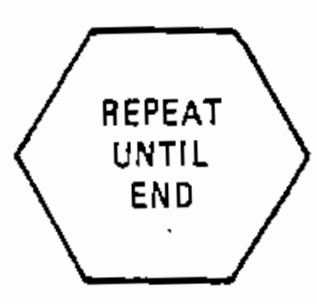

STEP 6

INSTALL LIO
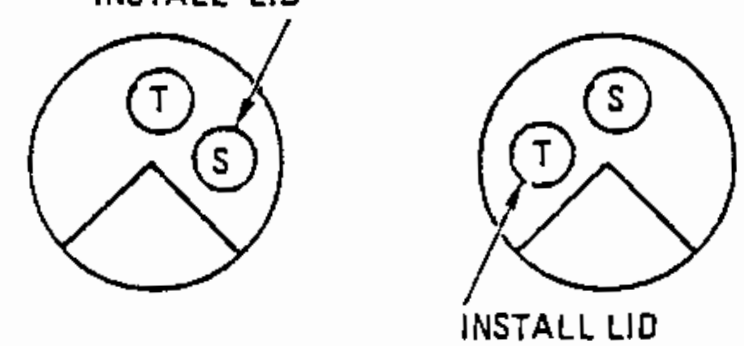

STEP 7

STEP 9

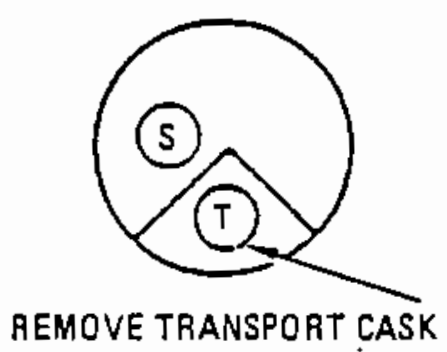

STEP 9

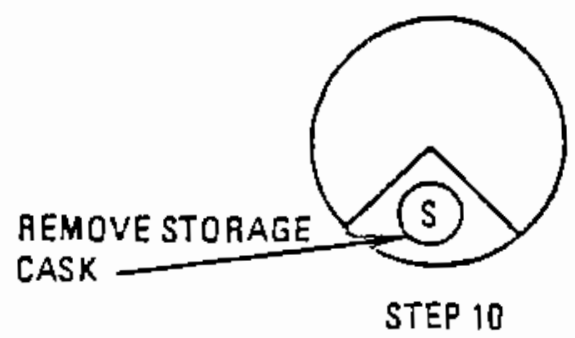

$S=$ STORAGE CASK

$T=$ TRANSPORT CASK

FIGURE 4.2. Cask Movement Sequence for Loading a Storage Cask - Turntable Concept 
TABLE 4.2. Operating Times for Shipping Cask Turnaround

Transport Cask

Personnel

Operation Time, hrs.

Elapsed Time, hrs.

Required

Rail

Rail Truck

Prepare for Transfer

A Receive and inspect transportation system

2

B Perform radioiogical

survey and wipe down

c Prepare to remove cask

2

D Remove cask from vehicle

3

E Remove outer closure

2

Intercask Transfer

$F \quad$ Receive and place storage

3

$-\cdots-2.0-\cdots$

9.5

7.5

cask and tumtable, rotate

and remove inner lid

G Prepare to remove inner

closure of transport cask

2

H Place transport cask on turntable, rotate and remove

1.5

1.5

1.5

1.5

3

$1.5 \quad 1.5$

3.0

3.0

inner lid

I Transfer cask contents, verify

2

$2.0-4.0^{\mathrm{a}}+1-1.5^{\mathrm{a}}$

$14.5^{\mathrm{a}}$

$10.5^{\mathrm{a}}$

$J$ Replace inner lid on both

2

2.0

1.5

76.5

12 casks

\section{2}

1.5

1.0

18

13

L Secure inner closure and move cask from turntable

$2.0 \quad 1.5$

20

14.5

$M$ Items $A, B, C, D, E$ are done on next transport cask during steps $F$ through $L$

N Repeat steps $G, H, I, J, K$ for next transport cask

$10.5-12.5 \quad 7.0-7.5$

30.5

2]

- Repeat step $N$ for more

2

21

14.5

62

166 transport casks
rage is full 
TABLE 4.2. (contd)

\begin{tabular}{|c|c|c|c|c|c|c|}
\hline & & $\begin{array}{l}\text { Personnel } \\
\text { Required }\end{array}$ & $\frac{\text { Operation }}{\text { Raij }}$ & $\frac{\text { Time, hrs. }}{\text { Truck }}$ & $\begin{array}{l}\text { Transport } \\
\text { Elapsed I } \\
\text { Rail }\end{array}$ & $\begin{array}{l}\text { Cask } \\
\text { me, hrs. } \\
\frac{\text { Truck }}{\text { Trut }}\end{array}$ \\
\hline & \multicolumn{6}{|l|}{ Prepare for Dispatch } \\
\hline & $\begin{array}{l}\text { Secure inner closure of } \\
\text { transport cask }\end{array}$ & 2 & 2.0 & 1.0 & 22 & 15.5 \\
\hline & $\begin{array}{l}\text { Replace outer closure on } \\
\text { transport cask and secure }\end{array}$ & 2 & 1.5 & 1.0 & 23.5 & 16.5 \\
\hline & $\begin{array}{l}\text { Prepare and load trans- } \\
\text { port cask on vehicle }\end{array}$ & 3 & 2.0 & 1.0 & 25.5 & 17.5 \\
\hline & Prepare for dispatch & 2 & 1.0 & 1.0 & 26.5 & 18.5 \\
\hline & $\begin{array}{l}\text { Move vehicle out, health } \\
\text { physics survey, install } \\
\text { personnel barriers }\end{array}$ & 2 & 2.0 & 1.5 & 28.5 & 20 \\
\hline & Inspect and sign off & $1-2$ & 0.5 & 0.5 & 29 & $\underline{20.5}$ \\
\hline & $\begin{array}{l}\text { Total for Transport Cask - } \\
\text { (excludes } M, N, 0)\end{array}$ & & & & $29-31$ & $20.5-21$ \\
\hline & $\begin{array}{l}\text { Remove storage cask from } \\
\text { turntable, load onto on- } \\
\text { site transporter }\end{array}$ & 2 & 1.5 & 1.5 & & \\
\hline & $\begin{array}{l}\text { Secure inner and outer } \\
\text { lids }\end{array}$ & 2 & 2.0 & 2.0 & & \\
\hline & Prepare for dispatch & 2 & 1.0 & 1.0 & & \\
\hline & $\begin{array}{l}\text { Move vehicle out, health } \\
\text { physics survey }\end{array}$ & 2 & 1.0 & 1.0 & & \\
\hline & Inspect and sign off & $1-2$ & 0.5 & 0.5 & & \\
\hline & Total for storage cask & & $.5-49.5^{\mathrm{b}}$ & $52.5-85^{b}$ & & \\
\hline
\end{tabular}

\footnotetext{
a. Low nunber only is used for accumulated time in table. High number is also included in total time at bottom of table.

b. Totals = elapsed time for transport cask through item $L$, plus times for items $\mathrm{N}$ plus 0 , plus accumulative times for $i$ tems $Y$ through $Z$.
} 
For each 2.4 rail casks containing ten PWR fuel assemblies each $(0.461$ MTU/assembly), one storage cask must be handled. This storage cask handling requires eight hours additional time for each 62 hours of rail shipping cask handing time. Thus, the total time requirements for rail casks to fill one storage cask is $62+8=70$ working hours. This translates to $3.79 \mathrm{MTU} /$ day or 53 days for 200 MTU. As for the truck cask handling capability, this capacity may be optimistic for the long term.

For half the spent fuel or canisters shipped by truck and half by rail, total operating days required is $131+53$, or 184 . This is less than the nominal 250 operating days specified. Thus, even with some relaxing of scheduling activities, the handling capacity of the turntable system is a dequate.

\subsection{COSTS}

The high-spot costs for the turntable concept, estimated in mid-1982 dollars, are given in the following subsections. A contingency of $30 \%$ is included in all costs. The costs have not been converted to a present worth basis. Bases and details of the cost estimates are given in Appendix $E$.

\subsubsection{Design, Construction, and Shakedown Costs}

The capital costs for the turntable concept were estimated to be $\$ 13.2$ million, including design and construction and the transporter for moving storage casks to the on-site storage. The costs are sumarized in Table 4.3. The allowance for design (20\% of capital) is higher than that for the other concepts to reflect the more complex mechanical systems.

\subsubsection{Operating Costs}

Operation of the intercask transfer facility encompasses the steps shown in Table 4.2. From these operations, the staffing requirements for the total facility were estimated by this author as shown in Table 4.4 (based on those estimated for the trench concept). 
TABLE 4.3. Capital Cost Summary for the Turntable Concept ${ }^{\text {(a) }}$

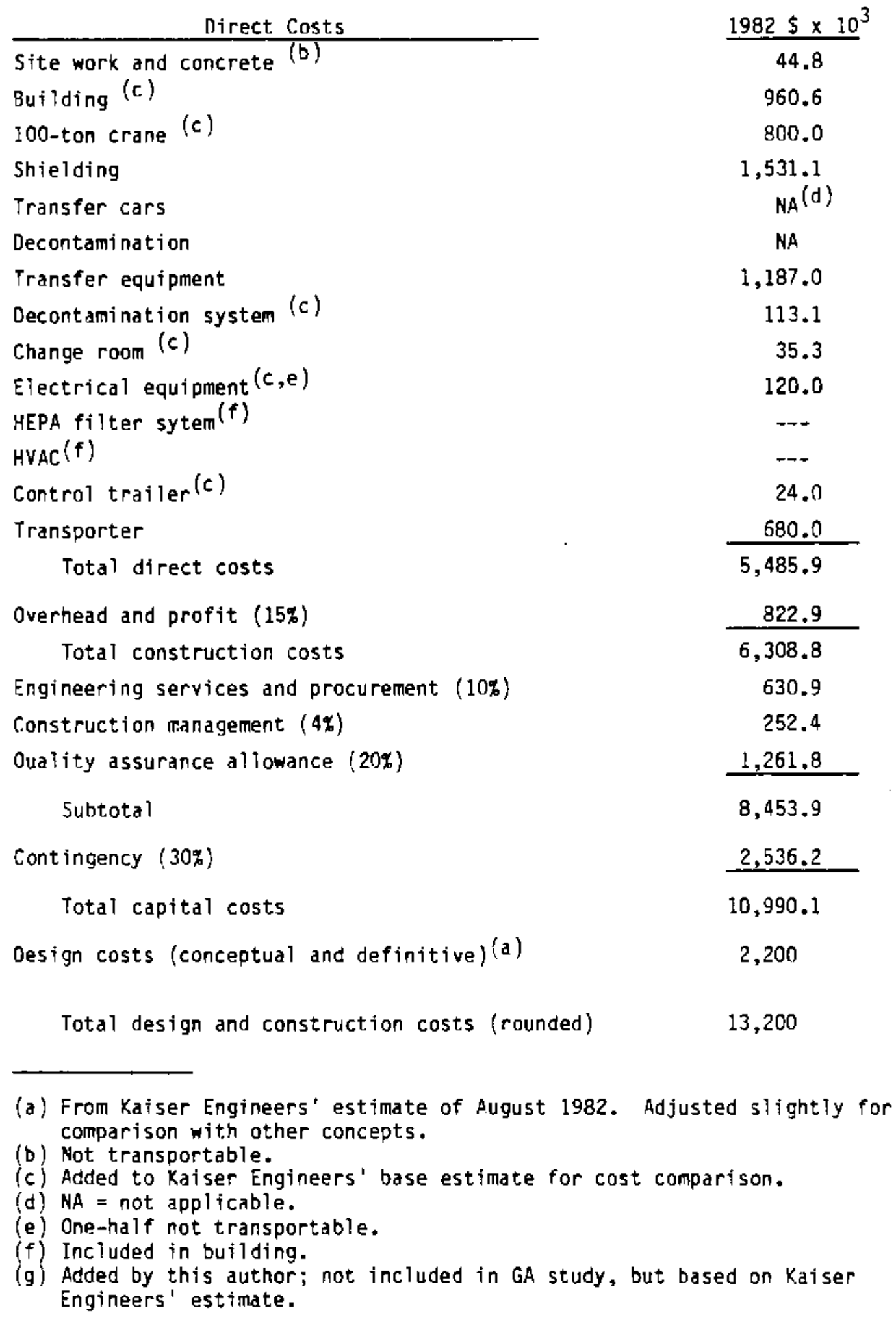


TABLE 4.4. Estimated Operating Staff for the Turntable Concept.

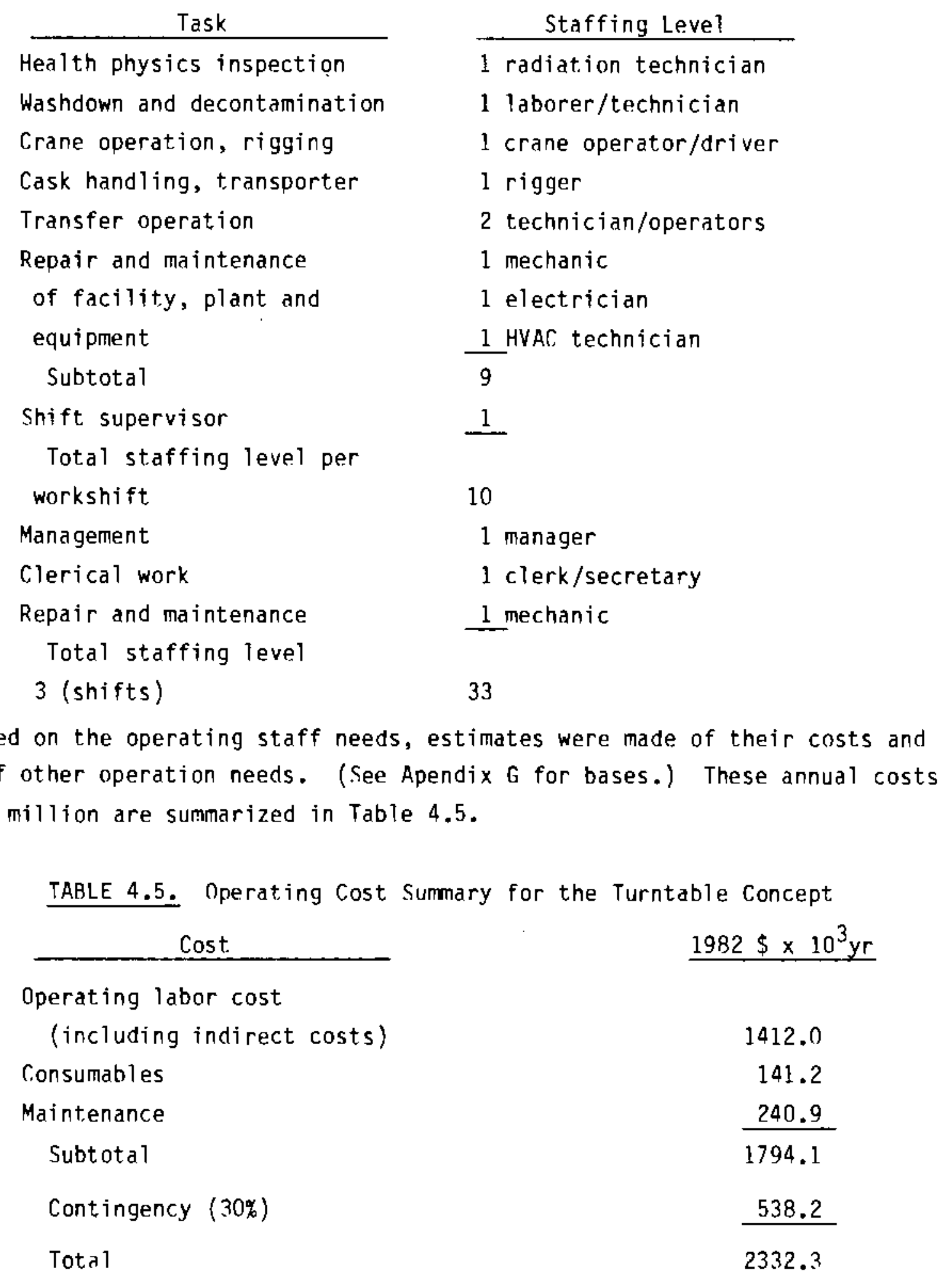

4.16 


\subsubsection{Relocation Costs}

The relocation costs (estimated by this author) consist of costs for disassembly, preparation for shipment, loading and unloading, and reassembly and inspection of transportable items at the new site. Also included are the costs of the nontransportable portion of the facility (concrete slabs, etc.) to be duplicated at the new site, and power and lighting costs. Freight is not included in the relocation costs, which are estimated to be $\$ 1.1$ million and are given in Table 4.6 .

TABLE 4.6. Relocation Costs for the Turntable Concept $(a)$

\section{Costs}

Nontransportable part of facility to be duplicated at new site

Preparation for shipment, disassembly, loading, and unloading

Shipping

Assembly and inspection at new site

Power and 1 ighting

Total direct cost

Overhead and profit (15\%)

Total construction cost

Procurement $(1.8 \%)$

Construction management (3\%)

Quality assurance allowance (20\%)

Subtota 1

Contingency (30\%)

Total without freight (rounded)
$1982 \$ \times 10^{3}$

45

$200^{\circ}$

Not included

300

60

605

91

696

11

$1 B$

121

846

254

1,100

(a) Developed by this author using bases in Reynolds (1982) and Griffin and Spritzer (1983). 


\subsection{IMPLEMENTATION SCHEDULE}

The schedule for implementation of the turntable concept for the intercask transfer equipment (shown in Figure 4.3) is estimated to be 41 months after initiation of conceptual design (Howard, 1982, in Appendix G).

The turntable concept includes some complex automated mechanisms and is not of conventional design. Some nonstandard construction techniques are required. Thus, the implementation schedule is relative long.

It is estimated that relocation would require about 10 months. Disassembly of the existing facility would need to be phased with the small amount of new construction at the new location.

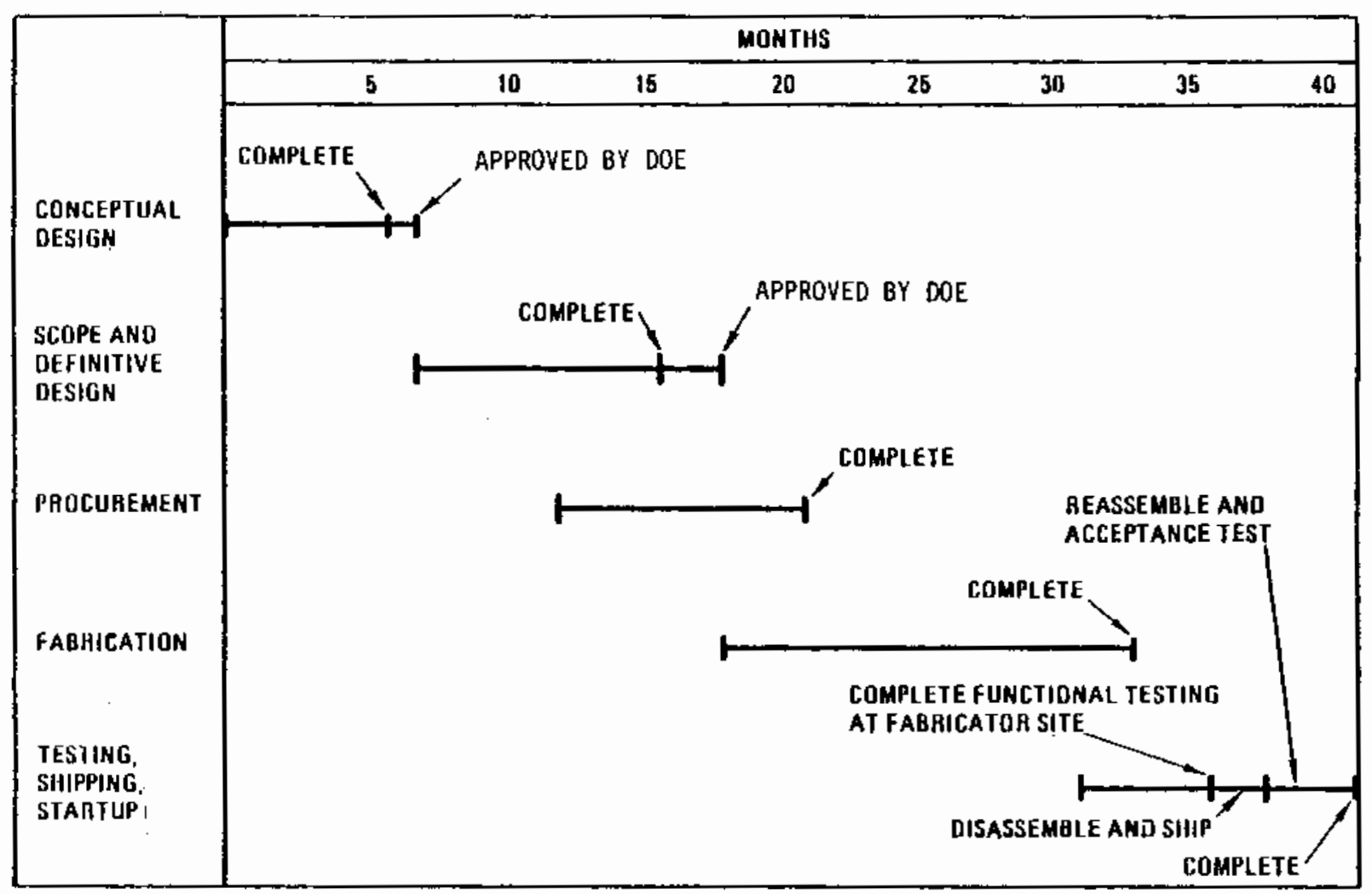

FIGURE 4.3. Implementation Schedule for Turntable Concept 
Baer, J.W. 1982. Preliminary TEF/PF Interface Criteria Report. GA Technologies, San Diego, California.

Franklin, A. L. September 1981. Evaluation of Improvement Potential for Spent Fuel Cask Handling. PNL-3722, Pacific Northwest Laboratory, Richland, Washington.

Griffin, R. and M. H. Spritzer. January 1983. Preconceptual Design of Intercask Transfer Equipment. GA Technologies, Inc., San Diego, California.

Howard, M. J., Kaiser Engineers Hanford, letter to K. J. Schneider, PNL, August 18, 1982 (see Appendix E, p. E.2).

McCreary, P. N. 1981. Operational Assessment of the Transnuclear TN-9 Truck Spent Fuel Shipping Cask. AGNS 35900-1.1-159. Allied General Nuclear Services, Barnwell, South Carolina.

Reynolds, R. K. October 1982. Spent Fuel Transfer Facility-Concept Study. Raymond Kaiser Engineers, Oakland, California. 



\subsection{SHUTTLE CONCEPT}

The shuttle concept for a intercask transfer system was conceived by the staff at GA Technologies (Griffin and Spritzer 1983) under a contract with DOE's Commercial Spent Fuel Management Program nffice at the PNL. The information in this section is based on that work.

\subsection{DESCRIPTIDN}

The shuttle concept for intercask transfer, shown in Figure 5.1, consists primarily of a shielded fuel handiing machine mounted on a bridge-like structure that allows for horizontal movement (shuttling) of shipping and storage casks under it. The shuttle is located inside a portable, prefabricated metal building that provides the capability to receive and dispatch Targe metal storage casks, and shipping casks that are transported by truck or rail. The casks are received outside the building and are placed in the upright position on their respective cask shuttle cars by a large outside crane. The shuttle cars move the spent fuel or canisters under the shielded fuel handling machine where the openings are mated. The cask lids are removed and temporarily stored in sealed cavities. Fuel or canisters are first lifted out of the shipping cask by a grapple and lifting mechanism in the fuel handling tower. The cars are shuttled so that the storage cask is moved under the transfer tower and the spent fuel or canisters are lowered and deposited. When the shipping cask is empty or the storage cask is full, the procedures are reversed and the casks are dispatched to their respective destinations.

The shuttle concept minimizes the volume and surface area of the shielded enclosure by using the shielding of the storage and shipping casks, plus shielded isolation valves and shielded fuel handling and closure handling machines.

The concept has many similarities to the turntable concept; the primary cask movements are linear instead of rotational, however.

\section{$5.1 .1 \underline{\text { Site }}$}

The overall site requirements would be similar to almost any other small, fixed nuclear fuel cycle facility at grade level. Site area needs include 



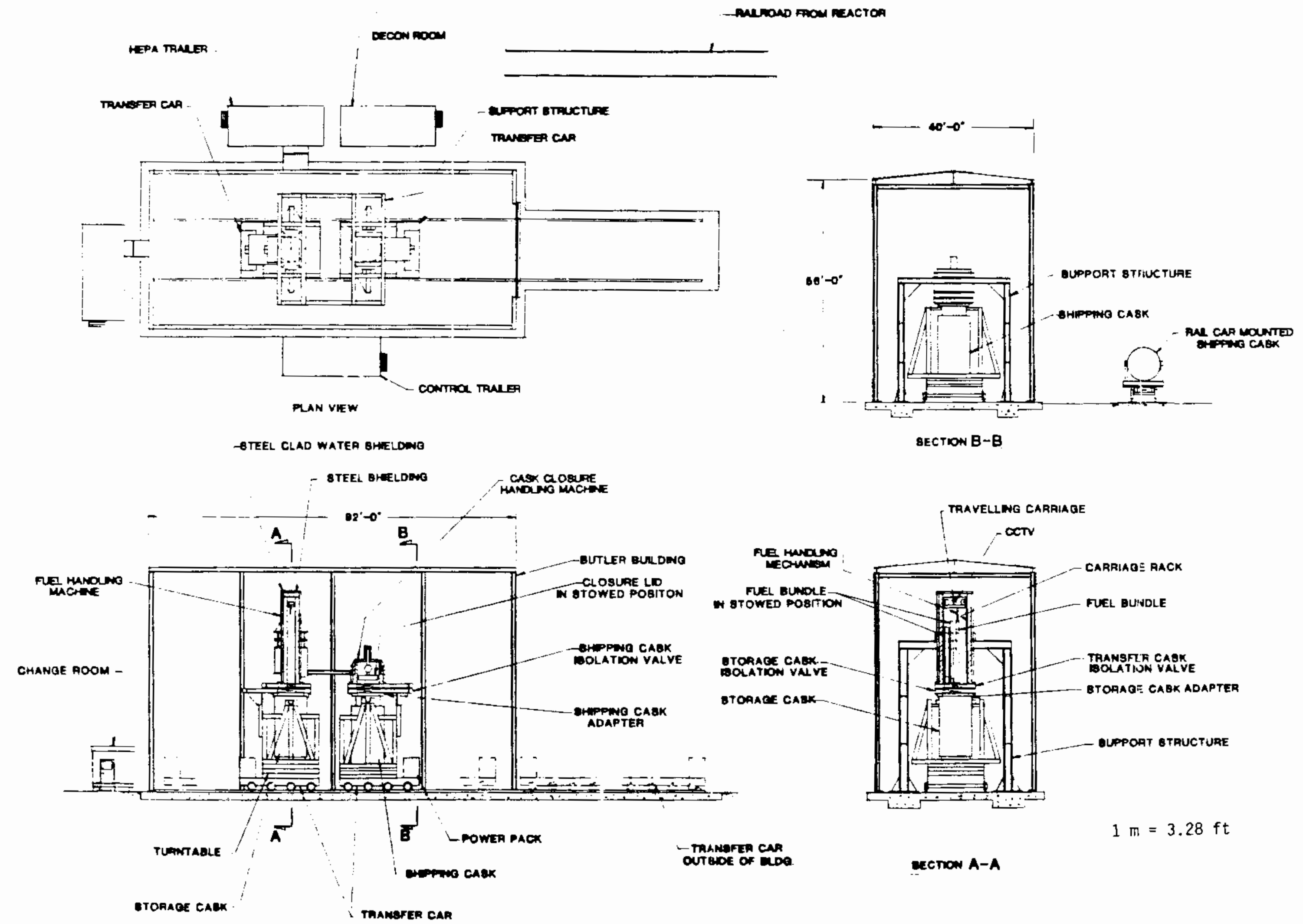
FIGURE 5.1. Shuttle Concept for Intercask Transfer (Griffin and



those for the main building, the portable ventilation annex building, the mobile homes used as change rooms, a decontamination equipment room, and an allowance for the outside parking of casks. The estimated size of the prefabricated building needed to meet the requirements of this concept is approximately $12.2 \mathrm{~m} \times 2.8 \mathrm{~m}(40 \mathrm{ft} \times \mathrm{g} 2 \mathrm{ft})$. The estimated minimal area need is on the order of $115 \mathrm{~m} \times 50 \mathrm{~m}$, or about 0.6 hectare. This is assumed to be approximately 4 times the dimensions of the major building.

\section{1 .2 Outer Enclosure}

The $17 \mathrm{~m}$-high main building is assumed to be a prefabricated and portable metal huilding with special sealing at joints and penetrations. The main building provides weather protection for the transfer operations, and provides a second level of confinement against potential releases of radioactive materials. The building is just large enough to house the fuel handing machine and the two transfer cars when they are under either of its operational ports or just away from their ports.

A concrete floor is provided as a foundation for the prefabricated building. Additional slabs for the portable support facilities are also required. One set of recessed rails is provided in the floor for each of the two shuttle transfer cars. The rails extend far enougb outside one end of the building for the transfer car to be moved entirely outside.

The casks and fuel handling machines are supported directly from the building floor, so special structures for an overhead crane are not needed. 5.1.3 Cask and Fuel Handling

The cask handling is done partly outside and partly inside the outer enclosure building. Spent fuel or waste handing and cask lid removal/ installation are done while the cask is mated to the shielded fuel handing machine and closure handing machine.

\section{Cask Handling}

Casks are brought just outside the main building on their over-the-road or on-site transport vehicle. The casks are lifted from their vehicles by a $100 \mathrm{Mg}$-capacity outside crane, then placed vertically on their respective positions on the transfer car as it sits just outside the building. Each selfpropelled transfer car is moved into the huilding. The outer cask lids (if 
any) are removed and inner cover bolts are removed. The casks are shuttled first beneath the closure handling machine where the lids are removed and stored, and then beneath the fuel handling machine where fuel is either removed or inserted into the casks. Motorized shielding slide valves (based on the design of HTGR refueling equipment) isolate the atmosphere inside the casks and the fuel handling machine from that of the building, and provide shielding during cask-shuttle operations.

The procedure is reversed for removing the casks. During transfer operations, the casks are shuttled back and forth beneath the fuel and closure handling machines. The radiation is confined within the system of casks and isolation valves.

\section{Fuel Handling Machine}

The fuel handling machine consists primarily of 1) a shielded fuel handling tower (shielding is equivalent to $30 \mathrm{~cm}$ of steel plus $15 \mathrm{~cm}$ of water), 2) a cask lid storage chamber, 3) four shielding sliding valves that mate the cask openings and the bottom of the transfer tower and lid storage chamber, 4) turntables and supports for casks on each of the two shuttle transfer cars, and 5) a structure to support items 1,2 and 3 .

The fixed-position steel-shielded fuel handing tower includes a grapple and lifting mechanism for vertical and one-dimensional horizontal movement of spent fuel and canisters. The bottom of the tower has its own integra? shielding slide valve that mates the slide valves above each of the cask openings. The cask lid storage chamber is provided for storing the inner lids of each of the shipping and storage casks. This chamber is provided with its own grappling and Tifting device. The lid storage chamber has its own inflatable seal and sliding valve to isolate the lifted lids from the building atmospheres. Each shuttle transfer car has a turntable for rotating the cask to provide access to all parts of the cask cavity by the fuel handling tower.

After both casks (on their shuttle cars) are in their respective positions under the handing mechanism, their inner lids are removed and temporarily 
stored. With the shipping cask in position beneath the transfer tower, the grapple in the tower grasps a spent fuel assembly or canister, lifts it into the tower, and deposits it into a holding location in the tower. This procedure is repeated for two more spent fuel assemblies or canisters.

The appropriate slide values are opened and closed. The shuttle transfer cars are shifted to replace and remove cask lids and to place the storage cask under the transfer tower. The above procedure is reversed to deposit the material into the storage cask, and is repeated until the shipping cask is empty and/or the storage cask is ful1. At this time, the inner cask lid is replaced on the last cask, and the shuttle cars are moved out from under the fuel handiing machine to be prepared for movement to their final destinations.

No capability is provided inside the fuel handling machine for repairing or recanning spent fuel or canisters.

\section{1 .4 Viewing}

Operations inside the fuel handling station are done remotely by staff in a control trailer adjacent to the building. A viewing window is provided to allow observation by the control operator inside the building. The mechanisms are automated and give continuous readout of positions.

Viewing inside the fuel transfer tower and cask lid storage chamber is accomplished through the use of closed-circuit television. The television cameras have pan, tilt and zoom capability. Specific lighting inside the mechanisms is provided for each of the cameras. One small lead-glass shielding window is located in each of the three chambers to assist in viewing, when desirable.

\section{1 .5 Ventilation}

The ventilation for the shuttle building is of conventional design with the flow of filtered and conditioned air into the operating area from the air conditioning system located on the roof. The pressure in the building is maintained slightly negative relative to atmospheric pressure by an exhaust 
fan system located in the adjacent portable fan/filter room. Before discharge to the atmosphere through the exhaust stack, all air from the building is filtered through High Efficiency Particulate Air (HEPA) filters, located in the adjacent fan/filter room.

Some of the building supply air flows directly into inlet ventilation ports in the fuel handling system. The air from this system is exhausted from other ports and routed directly to the fan/filter room for HEPA filtration before discharge out the stack. A larger, negative pressure is maintained within the shuttle mechanism to assure flow of air from the operating area to the fuel handling system.

Sufficient ventilation air, supplied inside and outside of the shuttle system, removes decay heat of the spent fuel or high-level waste via the ventilation system.

\subsubsection{Decontamination and Contamination Control}

General contamination control is accomplished using conventional operating practices, such as using plastic covers over areas that may become contaminated. A clothing change room for operating staff is located in a trailer adjacent to the main building.

Radiation monitoring equipment in the facility provides continuous surveillance of ambient radioactivity levels in all areas inhabitable by personnel. Radiation probes within the fuel handing chambers provide a continuous measure of the shield interior. Audiovisual alarms are activated when specified exposure rates are exceeded. The exhaust gases at the stack are also continuously monitored.

Essentially no decontamination of the spent fuel or canisters can be done using the shuttle system.

Decontamination and limited repair of shuttle assembiy parts can be accomplished in place and in the portable decontamination room. Decontamination solutions are available there for that use. Some decontamination of large parts of the shuttle system is done by personnel contact cleaning. 


\subsection{OPERATING SEQUENCES}

The normal operational sequences and estimated time requirements for intercask transfer of spent fuel or canisters using the shuttle concept are listed in Table 5.1 .

\section{TABLE 5.1. Operational Sequences in the Shuttle Concept}

Receive and prepare storage cask (required time: $3 \mathrm{hr}$ )

1. Move storage cask shuttle car to load/unload apron.

2. Lift storage cask onto storage cask shuttle car.

3. Move shuttle car into transfer building staging area.

4. Clean cask exterior as required.

5. Place lift attachment on storage cask lid.

6. Loosen fasteners on storage cask $7 i d$.

7. Lift and attach storage cask isolation valve to storage cask and connect power instrumentation and HEPA systems to valve.

8. Close valve and test seal.

Receive and prepare shipping cask (required time: $4 \mathrm{hr}$ )

1. Install appropriate fixtures on shipping cask shuttie car for particular shipping cask type.

2. Move shipping cask shuttle car to load/unload apron.

3. Lift shipping cask onto shipping cask shuttle car.

4. Move shuttle car into transfer building staging area.

5. Clean cask exterior as required.

6. Place lifting attachment on shipping cask lid.

7. Loosen fasteners on shipping cask lid.

8. Mount shipping cask adaptor ring on isolation valve.

9. Mount isolation valve on shipping cask and connect power instrumentation and HEPA systems to valve.

10. Close valve and test seal.

Remove fuel from shipping cask (required time: $2 \mathrm{hr}$ )

1. Move shipping cask under cask closure handing machine.

2. Effect overlap of shielding at isolation valve interface and establish sea?.

3. Test seal.

4. Open isolation valves.

5. Grapple and lift shipping cask lid.

6. Close and seal isolation valves.

7. Test seal.

8. Separate isolation valves and check for radiation.

9. Move shipping cask under fuel handling machine.

10. Rotate cask as required to grapple fuel elements.

11. Effect overlap of shielding at isolation valve interface and establish seal. 
TABLE 5.1. (contd)

12. Test seat.

13. Open isolation valves.

14. Translate and lower fuel handling mechanism and grapple fue? assembly.

15. Lift and store fuel assembly in fuel handling machine.

16. Repeat steps 14 and 15 up to two times (fuel handling machine can store a maximum of three fuel assemblies) if other fuel assemblies in the shipping cask are within reach of the fuel handling mechanism.

17. Close and seal isolation valves.

18. Test seat.

19. Separate isolation valves and check for radiation.

20. Repeat steps 10 through 19 up to two times (fue) handling machine can store maximum of three fuel assemblies) if the shipping cask must be rotated to reach other fuel assembities with the fuel handing fixture.

21. Move shipping cask under cask closure handling machine.

22. Effect overlap of shielding at isolation valve interface and establish seal.

23. Test seal.

24. Open isolation valves.

25. Lower shipping cask Iid into position, release, and retract grapple.

26. Close the isolation valve on closure handling machine.

27. Separate isolation valves and check radiation level.

28. Move shipping cask to staging area.

Load fuel into storage cask (required time: $2 \mathrm{hr}$ )

1-9. Repeat steps 1 through 9 of the prior activity for storage cask.

10. Rotate cask as required to align empty storage locations with the plane of the fuel handing mechanism.

11. Effect overlap of shielding at isolation valve interface and establish seal.

12. Test seal.

13. Open isolation values.

14. Translate and lower a grappled fuel assembly into an available storage position in the storage cask.

15. Ungrapple fuel assembly and retract fuel handling mechanism.

16. Repeat steps 14 and 15 up to two times if empty storage positions are within reach of the fuel handling mechanism.

17. Close and seal isolation valves.

18. Test seal.

19. Separate isolation valves and check for radiation.

20. Repeat steps 10 through 19 up to two times if the storage cask must be rotated to enable the fuel handing mechanism to reach empty storage positions.

21-28. Repeat steps 21 through 28 of the prior activity for storage cask. 
TABLE 5.1. (contd)

Decontaminate and remove shipping cask (required time: $3 \mathrm{hr}$ )

1. Survey and decontaminate isolation valve or cask lid, if required when shipping cask is moved to staging ared.

2. Remove isolation valve.

3. Tighten fasteners on shipping cask lid.

4. Survey and decontaminate isolation valve, if required.

5. Survey and decontaminate cask and lid, if required.

6. Remove lifting attachment from shipping cask lid.

7. Move shipping cask shuttle car out of building to load/unload apron.

8. Lift shipping cask from shuttle car and place on truck or rail transporter.

Decontaminate and remove storage cask (required time: $3 \mathrm{hr}$ )

1-8. Repeat steps 1 through 8 of the decontamination and removal (of the shipping cask) for the storage cask once it has been moved to the staging area.

\subsection{SYSTEM CAPACITY}

The major operational steps required to receive, handie, unload, and dispatch a truck cask and a rail cask for the shuttle concept were shown in Table 5.1. Also shown in Table 5.1 are the estimated required elapsed time for each major grouping of activities. With allowance for simultaneous operations, approximately 10 hours is required to turn around an average truck shipping cask containing two PWR fuel assemblies.

For each 12 truck casks containing 2 PWR fuel assemblies (0.461 MTU/ assembly), one storage cask must be handled. This storage cask handing requires 6 hours additional time for each $12 \times 10$ or 120 hours of truck shipping casks, or $120+6=126$ working hours. This translates to $2.1 \mathrm{MTU} /$ day or $525 \mathrm{MTU} / \mathrm{yr}$. Handling of the larger rail casks was not estimated, but based on the estimate for the turntable, should require no more than half the time per fuel element compared to truck casks. Thus, the capacity should be ample, with a reasonable allowance for unscheduled decontamination and maintenance for the system as conceived. 


\subsection{COSTS}

The high-spot costs for the shuttle concept, estimated in mid-1982 dollars, are given in the following subsections. A contingency of $30 \%$ is included in all costs. The costs have not been converted to a present worth basis. Bases and detajis of the cost estimates are given in Appendix $F$. 5.4.1 Design, Construction, and Shakedown Costs

The reported costs for the shuttle concept were estimated to be $\$ 70.6$ million, including the transporter for moving storage casks to the onsite storage, and design and construction. The costs are summarized in Table

5.2. Construction costs include overhead and profit. The allowance for design (17\% of capital) is higher than that for all other concepts except the turntable concept. because of the complex mechanical systems required by the shuttle concept.

\subsubsection{Operating Costs}

Operation of the intercask transfer facility encompasses the steps shown in Table 5.1. From these operations, staffing requirements for the total facility were estimated to be a total of 30 staff members. This includes one additional mechanic added by this author to the estimate by GA staff.

Estimates were made of staff costs and other operating costs. (See Appendix $F$ for bases.) These annual costs of $\$ 2.1$ million are summarized in Table 5.3.

\subsubsection{Relocation Costs}

The relocation costs consist of costs for disassembly, preparation for shipment, loading and unloading, and reassembly and inspection of transportable items at the new site. Also included are the costs of the nontransportable portions of the facility (concrete slabs, etc.) to be duplicated at the new site, and power and lighting costs. Freight is not included in the relocation costs, which are estimated to be $\$ 1.0$ million and are given in Table 5.4 . 
TABLE 5.2. Capital Cost Summary for the Shuttle Concept

Direct costs

Site work and concrete(a)
Building
100-ton crane
Shielding
Transfer cars
Decontamination coating
Transfer equipment
Decontamination system
Change room
Electrical equipment
HEPA f f lter system
HVAC (d)
Control trailer
Transporter

Total direct costs

Overhead and profit (15\%)

Total construction cost

Engineering services and procurement (10\%)

Construction management $(4 \%)$

Quality assurance (20\%)

Subtotal

Contingency $(30 \%)$

Total capital costs

Design Costs (17\% of total capital) $(\mathrm{e})$

Tota 1 Design and Construction Costs (rounded)

\section{$1982 \$ \times 10^{3}$}

58.8

515.3

800.0

473.1

500.0

NA

$1,215.0$

88.0

35.3

120.0

24.0

--

24.0

680.0

$4,533.5$

680.0

$5,213.5$

521.4

208.5

$\underline{1,042.7}$

$6,986.1$

$\underline{2,095.8}$

$9,081.9$

$\underline{1,540.0}$

10,600

(a) not transportable

(b) NA - not applicable

(c) one-half not transportable

(d) included with building

(e) added by this author; not included in the GA study, but based on Kaiser Engineer's estimate for the turntable concept (Reynolds 1982) 
TABLE 5.3. Operating Cost Sumary for the Shuttle Concept Costs

$1982 \$ \times 10^{3}$
1,284
$\frac{128}{1,594}$
$\frac{478}{2,070}$

TABLE 5.4. Relocation Costs for Shuttle Concept

$\begin{array}{lr}\text { Operating Tabor cost } & 1,284 \\ \text { (including indirect costs) } & 128 \\ \text { Consumables } & -182 \\ \text { Maintenance } & 1,594 \\ \text { Subtotal } & -478 \\ \text { Contingency (30\%) } & -2,070 \\ \text { Total (rounded) } & \end{array}$

\section{Costs}

Nontransportable part of facility to be duplicated at new site

Preparation for shipment, disassembly, loading, and unloading

Shipping

Assembly and inspection at new site

Power and lighting

Total direct costs

Overhead and profit (15\%)

Total construction cost

Procurement $(1.8 \%)$

Construction Management. (3\%)

Quality assurance allowance (20\%)

Subtotal

Contingency $(30 \%)$

Total without freight. (rounded)
$1982 \$ \times 10^{3}$

58.8

200.0

Not included

230.0

60.0

548.8

82.3

631.1

11.4

18.9

126.2

787.6

236.3

1,020

5.14 


\subsection{IMPLEMENTATION SCHEDULE}

The schedule for implementation of the concept for the intercask transfer equipment, shown in Figure 5.2 , is estimated to be 24 months after initiation of the design and construction contract.

The shuttle concept includes some complex, automated mechanisms and is not entirely of conventional design. Some nonstandard construction techniques are required. The schedule assumes that the design phase effort, will capitalize on designs and prior experience used to design, fabricate, install, and operate HTGR refueling equipment.

It is estimated that relocation would require about 14 months. Disassembly of the existing facility would need to be phased with the small amount of new construction at the new location.

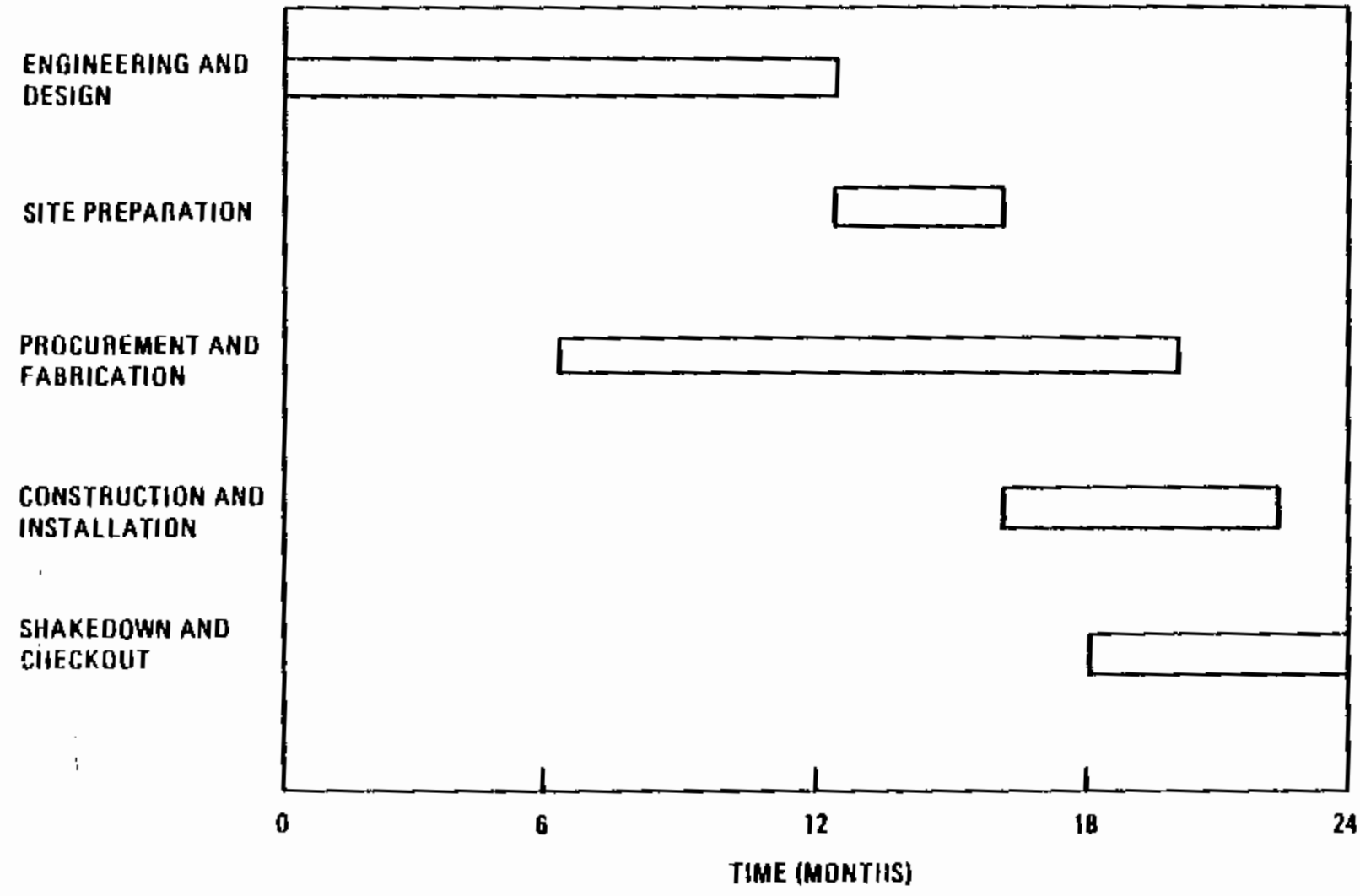

FigURE 5.2. Implementation Schedule for Shuttle Concept 


\section{REFERENCES FOR SECTION 5}

Griffin, R. and M. H. Spritzer. January 1983. Preconceptual Design of Intercask Transfer Equipment. GA Technologies, Inc., San Diego, California.

Reynolds, R. K. October 1982. Spent Fuel Transfer Facility - Concept Study. Kaiser Engineers Report RKE 81202-340, Kaiser Engineers, Richiand, Washington. 


\subsection{TRENCH CONCEPT}

The trench concept for a cask intertransfer system was conceived by the staff at GA Technologies (Griffin and Spritzer 1983) under a contract with the DOE's Commercial Spent Fuel Management Program Office at the PNL. The information in this section is taken from that work.

\subsection{DESCRIPTION}

The trench concept for intercask transfer, shown in Figure 6.1 , is based on conventional concepts for cask and spent fuel handling. The facility accepts licensed spent fuel shipping casks and large metal storage casks, transported by either rail or t.ruck, into a prefabricated-type building. Inside the building the casks are transferred by means of an overhead bridge crane, to a pair of cask transfer cars located in a short concrete-lined trench. Each of the cars conveys a cask along its trench into a shielded fuel transfer room (i.e., hot cell) where the fuel is remotely removed from the shipping cask and placed into a dedicated storage cask. After the storage cask is full of spent fuel or canisters, it is sealed remotely and moved out of the hot cell. It is lifted from the transfer car onto an on-site transporter on which it is moved from the building to an above-ground storage area. Empty transport casks are removed from the hot cell and lifted and placed anto their cross-country vehicles on which they are moved from the building to their offsite designation.

\section{1 .1 Site}

The overall site requirements would be similar to almost any other small, fixed nuclear fuel cycle facility at grade level. Site area needs include those for the main building, the portable ventilation annex building, the mobite home used as change room, a decontamination equipment room, and an allowance for outside parking of casks. The estimated size of the prefabricated building needed to meet the requirements of this concept is approximately $16.5 \mathrm{~m} \times 36.5 \mathrm{~m}(54 \mathrm{ft} \times 120 \mathrm{ft})$. The estimated minimal area need is on the order of $150 \mathrm{~m} \times 70 \mathrm{~m}$, or about 1 hectare. This is assumed to be approximately 


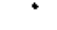




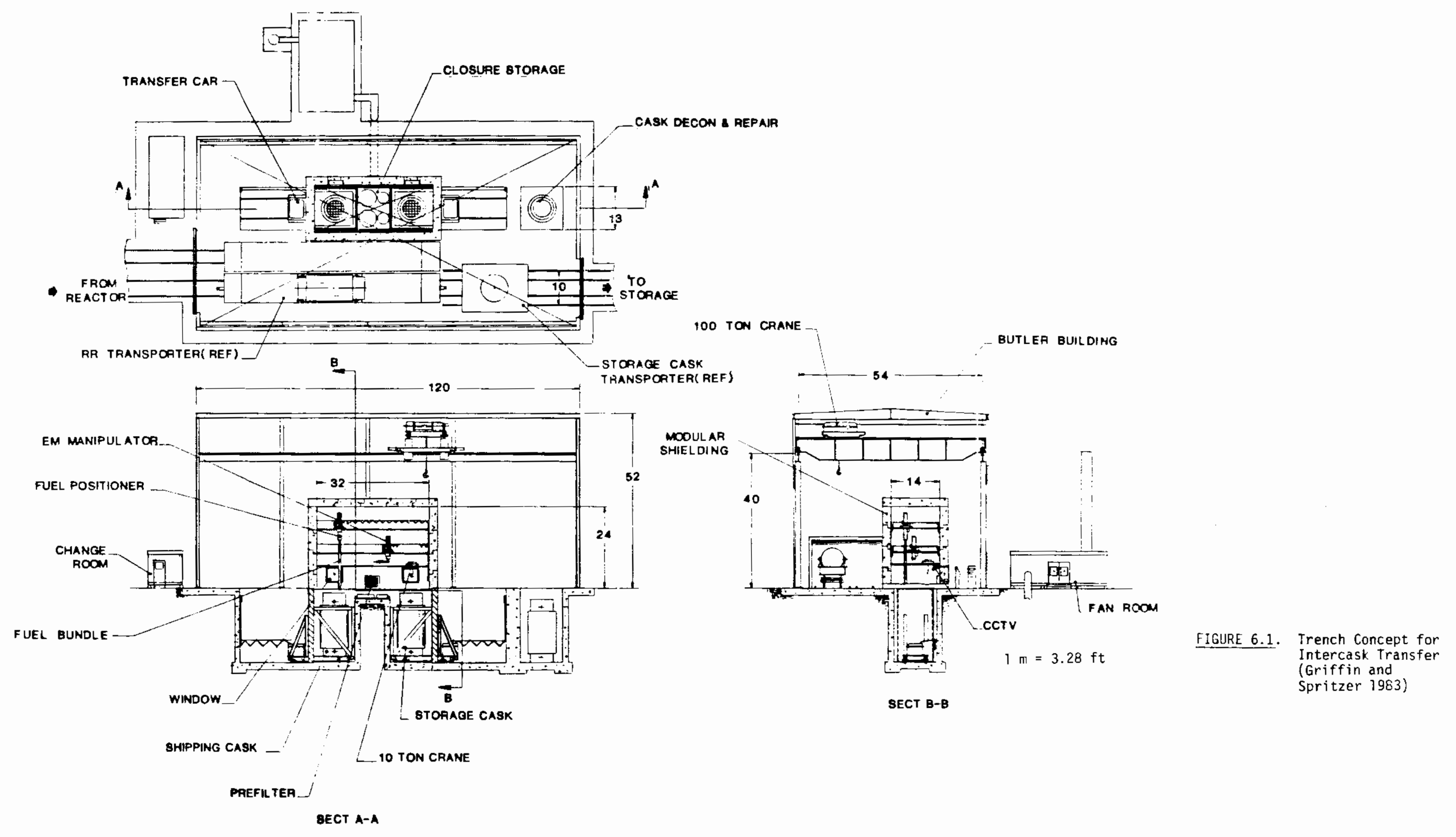



4 times the dimensions of the major building. The site is assumed to be part of a host site that will provide services such as administration, security, and health physics, and utilities such as electrical power, water, and steam.

Access into the facility by both rail and truck is needed to receive the shipping and storage casks. An additional rail spur to the storage cask parking area is also provided.

\subsubsection{0uter Enclosure}

The 15.2-m high main building is assumed to be a prefabricated and portable metal building with special sealing at joints and penetrations, and sufficient strictural members to support the large cranes and casks. The main building provides weather protection for the transfer operations, and provides a second level of confinement against potential releases of radioactive materials.

A concrete floor is provided as a foundation for the prefabricated building. Additional slabs for the portable support facilities are also required. Recessed rails are provided in the floor for the shipping cask and the storage cask vehicles, and for the on-site storage cask transporter.

Two segments of the trench, separated by a grade-level pad, provide semishielded cavities for the operation of the two cask transfer cars. A separate, small concrete-lined pit is provided in the building floor for cask decontamination.

\section{1 .3 Cask and Fuel Handling}

The cask handling and positioning is done inside the outer enclosure building. Spent fuel or waste handing and cask 7 id removal/installation are done inside the shielded fuel transfer room.

Cask Handling

Casks are brought into the main building on their over-the-road or on-site transport, vehicle. Inside the building the casks are lifted from their vehicles by a $100-\mathrm{Mg}-c a p a c i t y$ bridge crane that spans most of the area of the building, then placed on their respective transfer cars in the vertical position. The outer cask lids (if any) are removed and inner cover bolts are

\section{5}


removed. Each self-propelled transfer car is moved on its own rail tracks into the shielded fuel transfer room. Each car contains a steel shielding wall that mates and seals with the transfer room walls when the car is inside the room.

Renoval of the transport cask is done in the same manner in the reverse direction. Removal of the storage cask is done by placing the cask onto the onsite storage cask transporter, which takes the cask out of the facility to the FIS area.

\section{Shielded Fuel Transfer Room}

A modular shield system is employed to isolate the fuel transfer operation within the facility from the operating personnel. Large concrete shield blocks, approximately $1.5 \mathrm{~m}$ thick, with steel-protected edges and corners, are designed to be stacked, using the overhead 100-Mg crane, to form the shielded fuel transfer room above the trench. Interlocking faces on mating blocks prevent radiation shine from within the room. Structural integrity is assured by tendons that pass through the modular shield blocks.

The trench is made discontinuous inside the transfer room by a grade-level pad that is used to hold cask lids and special tools during fuel handing. The two trench segments include the recessed rail tracks for the transfer cars.

Three independent rail systems are attached to the inside face of the modular shield to provide supports for the fuel handling equipment bridges. These bridges support. a l0-Mg bridge crane, an electromechanical manipuiator and fuel positioner (which is a trolley unit that incorporates a vertical telescoping tube assembly with a grapple on its lower end).

If additional handling of fuels or canisters beyond transfer between casks is required (e.g., recanning, rewelding of joints), additional space and capability would need to be added to the fuel transfer room.

Fuel Handling

After removal of the inner cask lid using the 10 -Mg crane, the fuel positioner is used to index onto and grasp one fuel assembly or canister, lift. it out of one cask, move horizontally to an indexed position over the other cask, and lower the material into the cask, then release it. The inner lids of the respective casks are then placed in position on the casks and the casks are removed by the transfer cars from the fuel transfer room to their former positions. 
If necessary, some capability could be provided in the fuel transfer room for repairing or recanning spent fuel or canisters.

\section{1 .4 Viewing}

Operation inside the shielded fuel transfer room is done remotely with operating personnel just outside the shielding walls of the room. General viewing is accomplished through two lead glass shielding windows in one long wall of the shielded fuel transfer room. Supplemental viewing, including closeups, is accomplished by using a closed-circuit television system installed in wall plugs.

Mercury vapor lighting is used inside the transfer room. The mercury vapor bulbs are housed in standard hot cell fixtures that are attached to the inside wall around each of the viewing windows. Bulbs and fixtures are remotely replaceable using the electromechanical manipulator. Power control is from the operating area via penetration plugs.

\section{1 .5 Ventilation}

The ventilation system is of conventional design with the flow of filtered and conditioned air into the operating area and fuel transfer room from the air conditioning system located on the roof. A negative pressure is maintained inside the building relative to the atmosphere by using an exhaust fan system lacated in the adjacent portable fan/filter room. Before discharge into the atmosphere through the exhaust stack, all air from the building is filtered through High Efficiency Particulate Air (HEPA) filters, located in the adjacent fan/filter room. The air exhaust port for the shielded room is located at floor level and is equipped with prefilters that can be changed remotely. A greater negative pressure is maintained within the transfer room to assure flow of air from the operating area to the transfer room. An auxiliary system operates to exhaust more air when one of the transfer cars is driven out of the room.

\subsubsection{Decontamination and Contamination Contro?}

Decontamination and limited repair of the casks can be accomplished in the decontamination pit. Decontamination solutions are pumped from a trajler outside the building to the pit for decontamination operations and are returned via a sump to the trailer for filtration and recycle. 
A 7 imited amount of decontamination of the spent fuet or canisters can be done inside the fuel transfer room using portable cleaning devices held by the manipulator. Decontamination of the fuel transfer room is done by contact cleaning while the room is empty.

General contamination control is accomplished using conventional operating practices, such as using plastic aprons over the casks while they are inside the fuel transfer room. A clothing change room for operating staff is located in a trailer adjacent to the main building.

Radiation monitoring equipment in the facility provides continuous survejllance of ambient radioactivity levels in all areas inhabitable by personnel. Radiation probes within the fuel transfer room provide a continuous measure of the shield interior. Audiovisual alarms are activated when specified exposure rates are exceeded. The exhaust gases at the stack are also continuously monitored.

\subsection{OPERATING SEDUENCES}

The normal operational sequences for intercask transfer of spent fuel or canisters using the trench concept is given in Table 6.1.

\subsection{SYSTEM CAPACITY}

The major operational steps required to receive, handle, unload, and dispatch a truck cask and a rail cask are shown in Table 6.2. For each major operational step, information is provided on the procedure, the number of personnel involved, the time required for each step, and the elapsed time. The information presented in Table 6.2 shows cask turnaround times of approximately 21 and 31 hours for truck and rail shipping casks, respectively (Baer 1982). These turnaround times are representative of what could be achieved by standard crews and use of standard equipment, and are used to estimate capacity here. 
TABLE 6.1. Operational Sequence in the Trench concept

Shipping Cask or Storage Cask Preparation

1. Receive cask from shipping and receiving area. Perform necessary monitoring, checking and paper work.

2. Lower cask into transfer car, verify orientation, and secure. (Note: keep no more than one transfer car out of the cell at one time)

3. Remove outer cover and store.

4. Remove inner cover attachments and store.

5. Place and secure lifting attachment for inner cover.

6. Install "bib" around cask and over top of transfer car.

7. Drive transfer car into fuel transfer room.

8. Lock shield wall (part of transfer car) into its frame and energize seals.

\section{Fuel Transfer}

1. Remove shipping cask inner cover and store.

2. Install seal surface protection ring.

3. Remove storage cask inner cover and store.

4. Install seal surface protection ring.

5. Verify orientation of shipping cask and contents.

6. Verify orientation of storage cask and contents.

7. Select transfer program for the particular casks.

8. Verify location and identification of each spent fuel assembiy.

9. Engage particular spent fuel assembly, raise assembly, and verify integrity.

10. Move spent fuel assembly from shipping cask to storage cask (or vice versa).

11. Lower spent fuel assembly into particular storage location and release grapple.

12. Verify identification and location. Log data.

13. Repeat steps 9 through 12 for remaining spent fuel assemblies.

14. Remove seal surface protection ring.

15. Inspect cask, including seal face.

16. Replace inner cover on shipping cask.

17. Replace cover on storage cask.

18. Check cask top and "plastic bib" for contamination.

19. Decontaminate (manipulator with in-cell vacuum cleaner).

20. De-energize seals and release the locks on shield wall.

21. Move transfer car plus cask out of transfer room.

\section{Preparation for Cask Return}

1. Replace inner cover attachments and secure.

2. Inspect for contamination.

3. Move cask to decontamination pit, if required.

4. Move transfer car to in-cell position.

5. Decontaminate and reinspect.

6. Move cask to shipping and receiving area, onto vehicle.

7. Perform necessary tie-down, check-out, and paperwork.

$$
6.9
$$


IABLE 6.2. Operating Times for Shipping Cask Turnaround

\begin{tabular}{|c|c|c|c|c|c|c|c|}
\hline \multirow[b]{2}{*}{ OPEAATION } & \multirow{2}{*}{$\begin{array}{l}\text { PEASONNEL } \\
\text { REQUIHED }\end{array}$} & \multicolumn{2}{|c|}{ OPEAATION TIME (hr) } & \multicolumn{2}{|c|}{ MANHOUAS } & \multicolumn{2}{|c|}{ ELAPSED TIME (hr) } \\
\hline & & AAIL & TRUCK & RAlL & TRUCK & RAIL & TRUCK \\
\hline \multicolumn{8}{|l|}{ PREPARE FOA TAANSFEA } \\
\hline $\begin{array}{l}\text { RECEIVE AND INSPECT } \\
\text { TAANSPORTATION SYSTEM }\end{array}$ & 2 & 1.5 & 1.5 & 3.0 & 3.0 & 1.5 & 1.5 \\
\hline $\begin{array}{l}\text { PERFORM RADIOLOGICAL } \\
\text { SLAVEY AND WASHDOWN }\end{array}$ & 3 & 1.5 & 1.5 & 4.5 & 4.5 & 3.0 & 3.0 \\
\hline PAEPARE TO REMOVE CASK & 2 & 1.5 & 1.0 & 3.0 & 2.0 & 4.5 & 4.0 \\
\hline $\begin{array}{l}\text { REMOVE CASK FROM } \\
\text { TRANSPORTER }\end{array}$ & 3 & 2.0 & 1.5 & 6.0 & 4.5 & 8.5 & 5.5 \\
\hline REMOVE OUTER CLOSURE & 2 & 3.0 & 2.0 & 6.0 & 4.0 & 9.5 & 7.5 \\
\hline \multicolumn{8}{|l|}{ INTEACASK TRANSFER } \\
\hline $\begin{array}{l}\text { PREPARE TO AEMOVE INNER } \\
\text { CLOSURE (CASK IN } \\
\text { TRANSFER CAA) }\end{array}$ & 2 & 3.5 & 2.0 & 7.0 & 4.0 & 13.0 & 9.5 \\
\hline $\begin{array}{l}\text { MATE CASK IIN TAANSFER } \\
\text { CAR) TO TAANSFER ROOM }\end{array}$ & 2 & 1.0 & 1.0 & 2.0 & 2.0 & 14.0 & 10.5 \\
\hline REMOVE INNER CLOSUAE & 2 & 1.0 & 0.75 & 2.0 & 1.5 & 15.0 & 11.25 \\
\hline TRANSFER CASK CONTENTS & 2 & $1.5 \cdot 3.0$ & $0.5 \cdot 1.5$ & B.D & 3.0 & 18.0 & 12.75 \\
\hline INSPECT CASK & 2 & 1.0 & 1.0 & 2.0 & 2.0 & 19.0 & 13.75 \\
\hline $\begin{array}{l}\text { CLOSE CASK IINNEA } \\
\text { CLOSUREY AND MOVE OUT } \\
\text { OF TAANSFER ROOM }\end{array}$ & 2 & 2.5 & 1.0 & 5.0 & 2.0 & 21.5 & 14.75 \\
\hline SECURE INNEA CLOSURE & 2 & 1.5 & 1.0 & 3.0 & 2.0 & 23.0 & 15.75 \\
\hline \multicolumn{8}{|l|}{ PREPARE FOR DISPATCH } \\
\hline $\begin{array}{l}\text { AEPLACE DUTER CLOSUAE } \\
\text { AND SECURE }\end{array}$ & 2 & 1.5 & 1.0 & 3.0 & 2.0 & 24.5 & 18.75 \\
\hline $\begin{array}{l}\text { PAEPAAE TO LOAD CASK } \\
\text { ON TAANSPOATER }\end{array}$ & 3 & 1.0 & 1.0 & 3.0 & 3.0 & 25.5 & 17.75 \\
\hline $\begin{array}{l}\text { PLACE CASK ON } \\
\text { TAANSPORTER }\end{array}$ & $2 \cdot 3$ & 1.5 & 1.0 & 4.5 & 3.0 & 27 & 18.75 \\
\hline PAEPARE FOR DISPATCH & $2 \cdot 3$ & 1.0 & 0.75 & 3.0 & 2.25 & 28 & 19.5 \\
\hline $\begin{array}{l}\text { MOVE TRANSPORTER OUT, } \\
\text { HEALTH PHYSICS SURVEY, } \\
\text { INSTALL PERSONNEL } \\
\text { GARRIERS }\end{array}$ & $1-2$ & 2.0 & 1.25 & 4.0 & 2.5 & 30 & 20.75 \\
\hline INSPECT AND SIGN OFF & $1-2$ & 0.5 & 0.5 & 1.0 & 1.0 & 30.5 & 21.25 \\
\hline TOTAL & & & & BB & 48 & & \\
\hline
\end{tabular}


Further studies of shipping cask handling times were reported by Mccreary (1981). A larger crew of skilled operators performed repeated runs with a TN-9 cask (a large truck cask) to build proficiency, to refine techniques, and to use certain special equipment. A cask turnaround time of approximately 12 hours was achieved, which shows that the capacities estimated here are conservative.

The shipping cask turnaround time is the controlling factor in determining facility capacity. Using shipping cask types NL $1 / 2$ and IF 300 , assuming a $50 / 50$ split of spent fuel quantities shipped by truck/rail, and assuming the spent fuel is all from PWRs, the required annual shipments for a 400 MTU capacity are:

$$
\begin{array}{ll}
\text { Truck: } & \frac{400 \text { MTU } / y r}{2(0.461 \text { MTU } / \text { shipment })}=434 \text { shipments } \\
\text { Rail: } & \frac{400 \mathrm{MTU} / \mathrm{yr}}{2(3.23 \mathrm{MTU} / \text { shipment })}=62 \text { shipments }
\end{array}
$$

Facility annual operating hours required for transfer are:

$$
\begin{aligned}
\text { Truck: } 434 \text { trips } \times 21 \text { hours } & =9,114 \text { hours } \\
\text { Rail: } \quad 62 \text { trips } \times 31 \text { hours } & =1,922 \text { hours } \\
\text { Total } & =11,036 \text { hours }
\end{aligned}
$$

The number of cask handling bays required for a $400 \mathrm{MTU} /$ year facility if operated 24 hours/day, 250 days/year (6000 hours/year) is 11,036/6000, or approximately 2. The concept as defined should thus have adequate capacity with its 2 bays, $(6000 \times 2 \times 400 / 11036$ or 435 MTU/yr). The conservation in the time estimates should compensate for decontamination and maintenance requirements not included.

\subsection{COSTS}

The high-spot costs for the trench concept, estimated in mid-1982 dollars, are given in the following subsections. The costs have not been converted to a present worth basis. A contingency of $30 \%$ is included in all costs. Bases and details of the cost estimate are given in Appendix G. 


\subsection{Design, Construction, and Shakedown Costs}

The capital costs for the trench concept were estimated to be $\$ 9.3$ million, including design and construction, and the transporter for moving storage casks to the on-site storage. The costs are sumarized in Table 6.3. Construction costs include overhead and profit.

\subsubsection{Dperating Costs}

Operation of the intercask transfer facility encompasses the steps shown in Table 6.2. From these operations, staffing requirements for the total facility were developed as shown in Table 6.4.

Estimates were made of staff costs and other operating costs. These annual costs of about $\$ 2$ million are summarized in Table 6.5 .

\subsubsection{Relocation Costs}

The relocation costs consist of costs for disassembly, preparation for shipment, loading and unloading, and reassembly and inspection of transportable items at the new site. Also included are the costs for the nontransportable portion of the factlity (concrete slabs, etc.) to be dupticated at the new site, and power and lighting costs. Freight is not included in the relocation costs, which are estimated to be $\$ 1.6$ million and are given in Table 6.6 .

\subsection{IMPLEMENTATION SCHEDULE}

The schedule for implementation of the trench concept for the intercask transfer equipment shown in Figure 6.2 is estimated to be 24 months after initiation of the design and construction contract.

The schedules for the design and construction phases are believed to be readily achievable because the trench concept is of conventional design and requires only standard construction techniques. The fuel transfer equipment. and controls are advanced in design and performance hut are selected from standard components and require mainiy that adequate lead time be given for their procurement.

It is estimated that relocation would require about 14 months, since most of the hardware and equipment would already be available. 0isassembly of the existing facility would need to be phased with construction at the new location. 
TABLE 6.3. Capital Cost Sumary for the Trench Concept

\begin{tabular}{|c|c|}
\hline Direct Costs & $1982 \$ \times 10^{3}$ \\
\hline $\begin{array}{l}\text { Site work and concrete (a) } \\
\text { Ruilding } \\
100 \text {-ton crane } \\
\text { Shielding } \\
\text { Transfer cars } \\
\text { Decontamination coating(a) } \\
\text { Transfer equipment } \\
\text { Decontamination system } \\
\text { Change room } \\
\text { Electrical equipment (b) } \\
\text { HEPA fijter system } \\
\text { HVAC (c) } \\
\text { Control trailer } \\
\text { Transporter }\end{array}$ & $\begin{array}{r}192.2 \\
873.6 \\
800.0 \\
150.0 \\
480.0 \\
57.0 \\
497.0 \\
113.1 \\
35.3 \\
120.0 \\
24.0 \\
-24 \\
24.0 \\
680.0 \\
\end{array}$ \\
\hline Total direct costs & $4,046.2$ \\
\hline Overhead and profit $(15 \%)$ & 606.9 \\
\hline Total construction coss & $4,653.1$ \\
\hline Engineering services and procurement (10\%) & 465.3 \\
\hline Construction management $(4 \%)$ & 186.1 \\
\hline Quality assurance allowance $(20 \%)$ & 930.6 \\
\hline Subtotal & $6,235.1$ \\
\hline Contingency $(30 \%)$ & $1,870.5$ \\
\hline Total Capital Costs & $8,105.6$ \\
\hline nesign Costs $\left(15 \%\right.$ of total capital) ${ }^{(d)}$ & $1, ?, 15$ \\
\hline $\begin{array}{l}\text { Tota } 1 \text { Design and Construction Costs } \\
\text { (rounded) }\end{array}$ & 9,320 \\
\hline
\end{tabular}

(a) Not transportable.

(b) One-half not transportable.

(c) Included with buifing.

(d) Added by this author; not included in GA study. 
TABLE 6.4. Estimated Operating Staff for Trench Concept

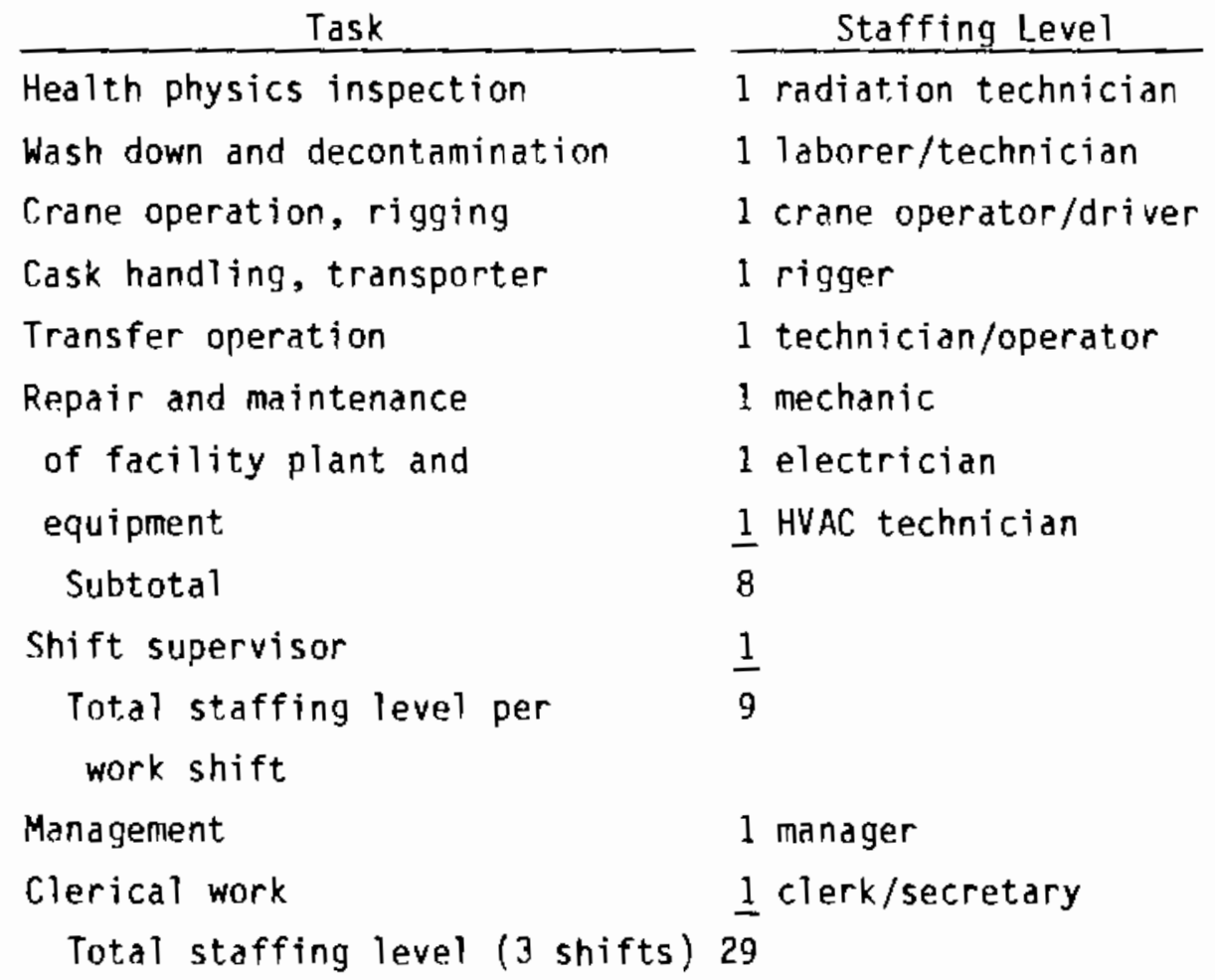

TABLE 6.5. Operating Cost Sumary for the Trench Concept

\begin{tabular}{lr} 
Costs & $1982 \$ \times 10^{3} / y$ \\
\hline $\begin{array}{l}\text { Operating labor cost } \\
\text { (including indirect costs) }\end{array}$ & 1241.2 \\
Consumabies & 124.1 \\
Maintenance & 162.1 \\
Subtotal & 1527.4 \\
Contingency (30\%) & $\underline{458.2}$ \\
Total (rounded) & 1990
\end{tabular}

6.14 
TABLE 6.6. Relocation Costs for the Trench Concept

\begin{tabular}{|c|c|}
\hline Costs & $1982 \$ \times 10^{3}$ \\
\hline $\begin{array}{l}\text { Nontransportable part of facility to be } \\
\text { duplicated at new site }\end{array}$ & 249.2 \\
\hline $\begin{array}{l}\text { Preparation for shipment, disassembly, loading, } \\
\text { and un roading }\end{array}$ & 250.0 \\
\hline Shipping & Not included \\
\hline Assembly and inspection at new site & 300.0 \\
\hline Power and lighting & 60.0 \\
\hline Total direct costs & 859.2 \\
\hline Overhead and profit $(15 \%)$ & 128.9 \\
\hline Total construction cost & 988.1 \\
\hline Procurement $(1.8 \%)$ & 17.8 \\
\hline Construction management $(3 \%)$ & 29.6 \\
\hline Quality assurance allowance (20\%) & 197.6 \\
\hline Subtotal & $1,233.1$ \\
\hline Contingency $(30 \%)$ & 369.9 \\
\hline Total without freight (rounded) & 1,600 \\
\hline
\end{tabular}




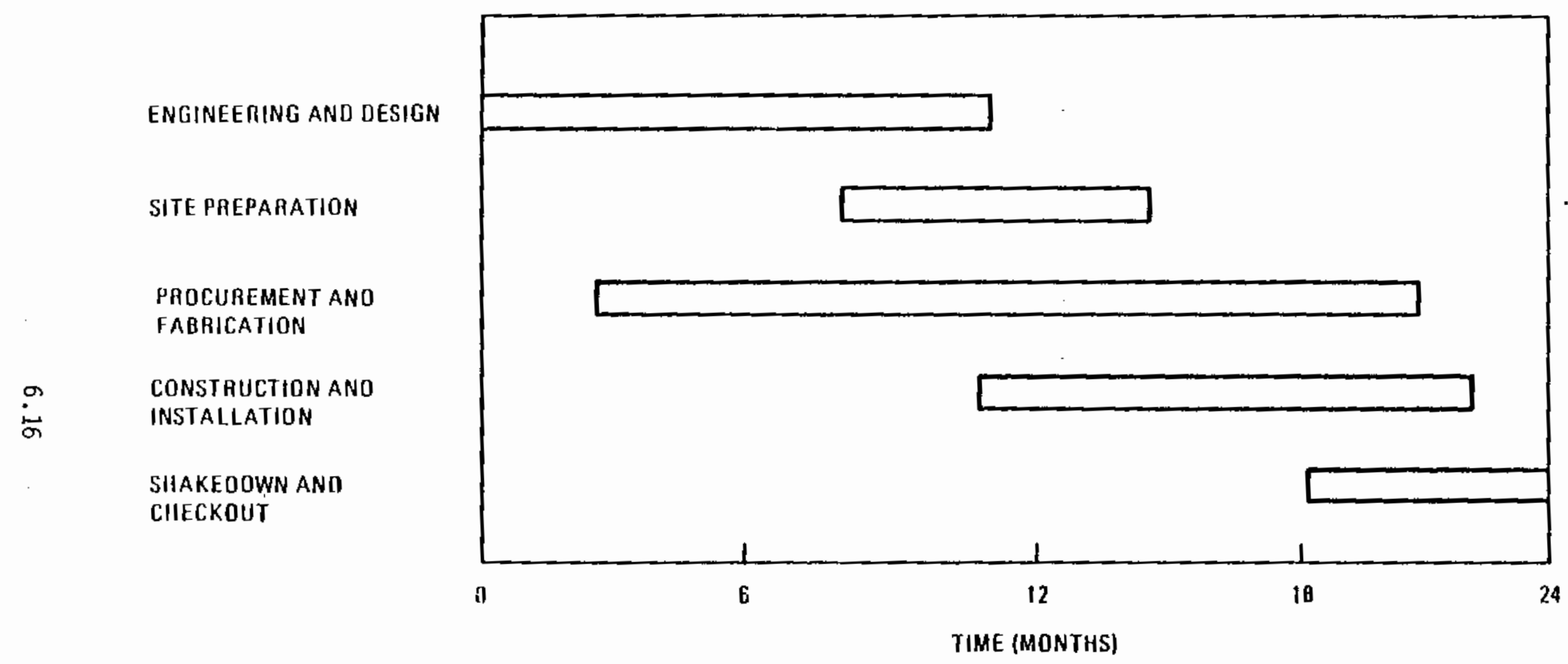

FIGURE 6.2. Implementation Schedule for Trench Concept 


\section{REFERENCES FOR SECTION 6}

Baer, J. W. 1981. "Preliminary TEF/PF Interface Criteria Report." GA Technologies Inc., San Diego, California.

Griffin, R. and M. H. Spritzer. January 1983. Preconceptual Design of Intercask Transfer Equipment. GA Technologies, Trc., San Diego, California.

McCreary, P.N. 1981. "Operational Assessment of the Transnuclear TN-9 Truck Spent Fuel Shipping Cask." AGNS 35900-1.1-159. Allied-General Nuclear Services, Barnwell, South Carolina. 



\subsection{IGLOO CONCEPT}

The igloo concept for a cask intertransfer system was conceived by the staff at Raymond Kaiser Engineers (Reynolds 1982) under a contract with DOE's Commercial Spent Fuel Management Program Office at the PNL. The information in this section is taken from that work, with some additional contributions from Griffin and Spritzer (1983).

\subsection{DESCRIPTION}

The igloo concept for intercask transfer, shown in Figure 7.1 , consists primarily of a fuel transfer chamber that houses fuel handling mechanisms and an outer decontamination room. These two chambers are in line at grade level;

an earthen berm provides shielding. The fuel transfer room functions similarly to that of a hot cell while the decontamination room functions as an air lock and a weather-protected service facility. The facility accepts and dispatches licensed spent fuel shipping casks and large metal storage casks, transported by either truck or rail. The casks are received outside the facility. A large outside crane places the casks in an upright position on a single transfer car. The transfer car moves the two casks into the shielded decontamination room where cask loading/unloading preparations are made. The transfer car is then moved into the transfer room and under a transfer tower where the cask lids are removed by mechanisms integral with the transfer car. The spent fuel or canisters are lifted into the transfer tower, then the car is moved so that the fuel or canister can be lowered and deposited into the storage cask. The procedure is repeated until the shipping cask is empty or the storage cask is full, and the cask lids are replaced. The casks are then moved into the decontamination room where preparations for dispatch of either the storage or shipping casks are performed.

\section{1 .1 Site}

The overall site requirements would be similar to almost any other sma!l, fixed nuclear fuel cycle facility at grade level. Site area needs include that for the igloo-type construction of the two chambers covered by the berm; for 



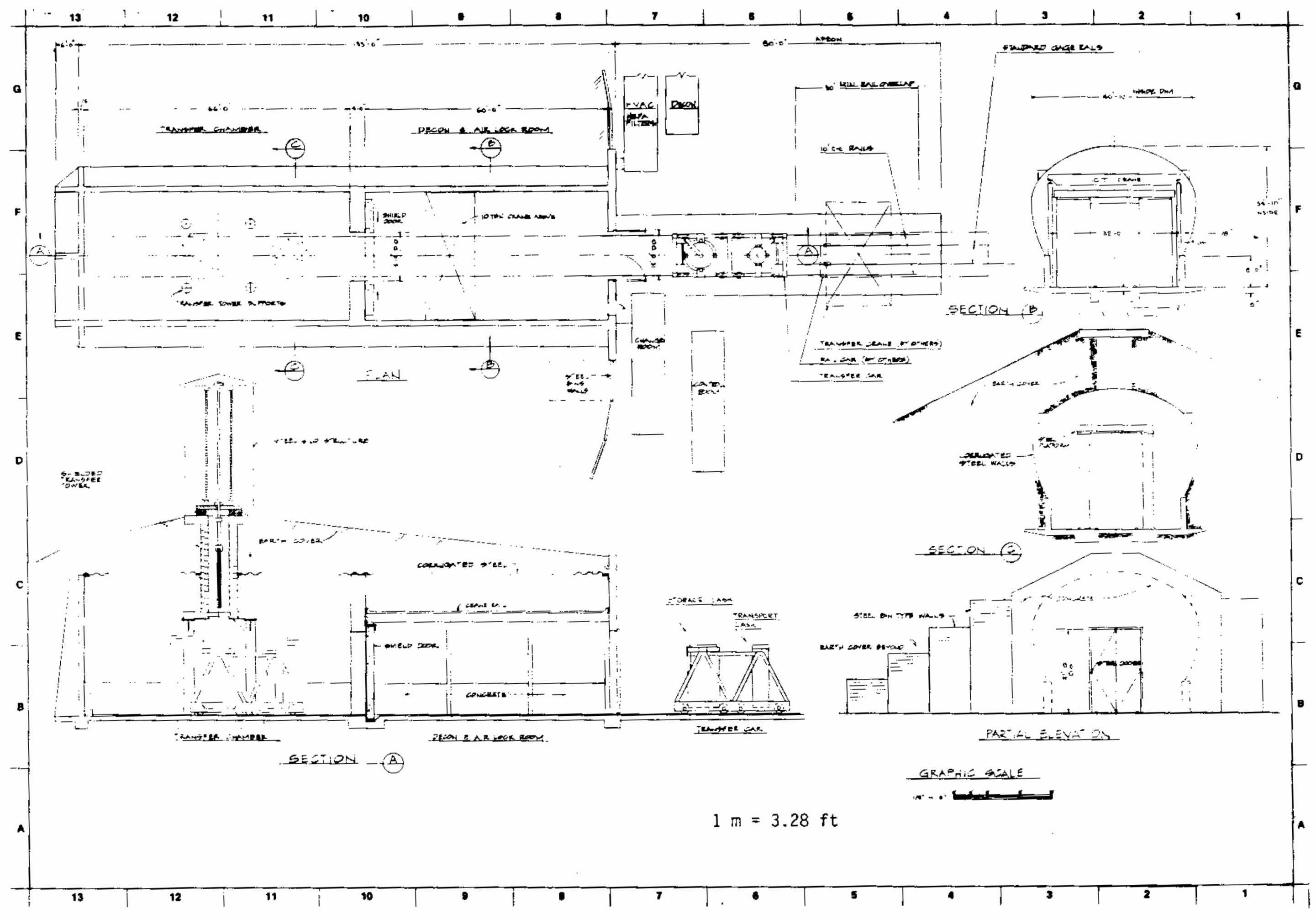

FIGURE 7.1. Igloo Concept for Intercask Transfer Reynolds (1982) 
the mobile ventilation, control, change and decontamination chemical facilities near the igloo; plus an allowance for outside parking of casks. The total size of the two rooms under the berm is $38.4 \mathrm{~m} \times 12.2 \mathrm{~m}(125 \mathrm{ft} \times 40 \mathrm{ft})$. The overall dimension of the berm is about $36.6 \mathrm{~m} \times 58 \mathrm{~m}(120 \mathrm{ft} \times 1 \mathrm{gn} \mathrm{ft})$. Sufficient fill dirt must be available to form the berm.

The estimated minimal area needed is on the order of $120 \mathrm{~m} \times 230 \mathrm{~m}$, or about 3 hectares. This is assumed to be approximately 4 times the dimensions of the berm.

The site is assumed to be part of a host site that will provide services such as administration, security and health physics, and utilities such as electrical power, water and steam.

Access to the facility by both rail and truck is needed to receive the shipping and storage casks. An additional rail spur to the storage and parking area is also provided.

\subsection{2 nuter Enclosure}

The primary outer enclosure consists of two parallel 2.4-m-high (and 38.4-m-long) concrete retaining walis, that are surmounted by a near-elipticalshaped commercial structure of galvanized corrugated plates that form the ceiling and rest of the walls. The total height of the igloo structure is $11.0 \mathrm{~m}$ and its maximum width is $12.3 \mathrm{~m}$. This structure is covered by an earthen berm that is up to $4.9 \mathrm{~m}$ thick and extends $15.9 \mathrm{~m}$ above grade. The igloo structure interior is divided into two long rooms in series by a concrete shielding wall and a concrete sliding shielding door: the decontamination and air lock room, and the fuel transfer chamber. A sealing steel door is located on the "open" end of the igloo to allow entrance of casks from outside into the decontamination and air lock room. A shielded fuel transfer tower supported by a bridge structure rises through the roof of the fuel transfer chamber. Above the transfer tower is a steel silo structure, $10.4 \mathrm{~m}$ high, that houses the mechanisms for handling the spent fuel and canisters. The igloo structure is on a concrete slab with embedded rails as a track for the on-site transfer car.

The igloo provides weather protection and shielding for the transfer operation, and provides for confinement against potential release of radioactive materials. 


\subsubsection{Cask and Fuel Handiing}

The cask handling is done partiy outside and partly inside the outer enclosure igloo. Spent fuel or waste handling and cask lid removal/ installation are done inside the shielded fuel transfer chamber.

\section{Cask Handling}

Casks are brought just outside the igloo on their over-the-road or on-site transport vehicle. The casks are lifted from their vehicles by a $100-\mathrm{Mg}-$ capacity outside crane, then placed vertically in their respective positions on the transfer car while the transfer car is just outside the igloo. The transfer car is moved into the igloo. The outer cask 1ids (if any) are removed and inner cover bolts are removed. The outer cask lids are removed by the 10$\mathrm{Mg}$ bridge crane in the decontamination and air lock room, and the casks are prepared for loading/unloaing. The personnel leave the igloo, the selfpropelled transfer car moves into the fuel transfer room and the shielding door between the two rooms is closed. The inner cask iids are removed by mechanisms mounted on the transfer car.

The procedure is reversed for removing the casks. During transfer operations, the transfer car is moved back and forth to a? ign the two casks beneath the fuel transfer tower.

Provisions are made for some decontamination of the casks and transfer car inside the decontamination and air lock room.

\section{Transfer Tower}

The shielded transfer tower is composed of interlocking rings of concrete. The top opening of the tower, at the top of the earthen berm, is enclosed with two horizontal sliding steel and plastic shielding plates. One member can rotate $360^{\circ}$, and the other can slide about $1.5 \mathrm{~m}$ to allow reaching any part of a storage cask cavity. The bottom of the tower includes a sliding shield valve that is not normally used, but can be closed in the event of a malfunction when spent fuel or canisters are inside the tower.

The hoist mechanism is located above the transfer tower in a silo housing that protects it from weather. The hoist mechanism moves horizontally and circumferentially with the sliding steel plates at the top of the transfer 
tower, as well as moving the fuel support vertically. The fuel support rod has a grapple at it.s lower end (in the transfer tower) to grasp spent fuel and canisters.

\section{Fuel Handling}

After the inner cask lids are removed and the fuel handling mechanism is indexed over the appropriate spent fuel assembly or canister, the grapple is lowered, grasps the material, and lifts it into the shielded transfer tower. The transfer car is moved to position the other cask under the transfer tower. The fuel handling mechanism is re-indexed to its appropriate position and the material is lowered into and deposited in the other cask.

This procedure is repeated until the supplying cask is empty or the receiving cask is full. At that point, the inner lids are placed onto the two casks by the two lid-lifting mechanisms and the transfer car is moved into the decontamination and air lock room for dispatch of the casks.

If necessary, some capability could be provided in the fuel transfer chamber for repairing or recanning spent fuel or canisters.

\section{1 .4 Viewing}

Operation inside the shielded fuel transfer chamber is done remotely with operating personnel in a control room trailer outside the berm. Closed circuit. television provides all necessary operator vision for the remotely controlled transfer operations. No shielding windows or manipulators are provided. Up to 10 closed-circuit television cameras are required in the two shielded chambers. The cameras are shielded and designed for in-cell viewing; five will have pan, tilt and zoom. Sodium vapor lighting is used inside the two shielded chambers.

\subsubsection{Ventilation}

The ventilation for the igloo building is of conventional design. Filtered and conditioned air flows into the igloo from an air conditioning system. The pressure in the building is maintained slightly negative relative to atmospheric pressure by using an exhaust fan system located in the adjacent portable fan/filter room. All air exhausted from each of the two rooms in the building is filtered through its own set of prefilters and High Efficency 
Particulate Air (HEPA) filters. It is pumped to the atmosphere by its own exhaust blower located in an adjacent ventilation trailer. Inside the fuel transfer chamber, which is maintained at a greater negative pressure than the other chamber, is another set of HEPA filters, upstream of its set of fina? filters in the ventilation trailer.

Sufficient ventilation air is supplied to the two shielded chambers to remove decay heat of the spent fuel or high-level waste via the ventilation system.

\subsubsection{Decontamination and Contamination Control}

Recontamination and limited repair of the casks can be accomplished in the decontamination and air lock room. Decontamination solutions are pumped from a trailer outside the huilding to the room for decontamination operations and are returned via a sump to the trailer for filtration and recycle.

Two hydraulic-operated, boom-mounted man/bucket units, generally similar to those used by utility companies for servicing street lighting and telephone overhead cable splices, are provided in the decontamination and air lock room. Each unit is mounted on the room floor by the transfer car trackway, one on each side. The units have capability for swinging and booming out to allow access to most surfaces of the casks and transfer car.

A limited amount of decontamination of the spent fuel or canisters is possible inside the fuel transfer chamber using built-in cleaning devices. Decontamination of the fuel transfer chamber is done by contact cleaning while the room is empty.

General contamination control is accomplished using conventional operating practices. This may include practices such as using plastic aprons over the casks while they are inside the fuel transfer room. A clothing change room for operating staff is located in a trailer adjacent to the igloo.

Radiation monitoring equipment in the facility provides continuous surveillance of ambient radioactivity levels in all areas inhabitable by personnel. Radiation probes within the transfer chamber provide a continuous measure of the shield interior. Audiovisual alarms are activated when specified exposure rates are exceeded. The exhaust gases are also continuously monitored. 


\subsection{OPERATING, SEQUENCES}

The normal operational sequences for intercask transfer of spent fuel or canisters using the igloo concept. are listed in Table 7.1.

\subsection{SYSTEM CAPACITY}

As noted, the major operational steps required to receive, handle, unload, and dispatch a shipping cask for the igloo concept are shown in Table 7.1. Also shown in Table 7.1 are the estimated required elapsed time for each major grouping of activities. With allowance for simultaneous operations, approximately 11 hours is required to turn around an average truck shipping cask containing two PWR fuel assemblies.

For each 12 truck casks containing 2 PWR fuel assemblies each (0.461 MTU/ assembly), one storage cask must be handled. This storage cask handing requires 6 hours additional time for each $12 \times 11$ or 132 hours of handling time for truck casks. Thus, the total time requirements for 12 truck casks is $132+$ $6=138$ working hours. This translates to $1.93 \mathrm{MTU} /$ day or $480 \mathrm{MTU} / \mathrm{yr}$. Handling of the larger rail casks will require less time per fuel element. Thus, the capacity should be ample, with a reasonable allowance for unscheduled decontamination and maintenance for the system as conceived.

As noted in Section 4.3, these estimates are based largely on good transfer rates using in-pool transfers, with some modifications. Experience has shown that decontamination needs (and therefore turnaround times) for dry transfers should be lower than for wet transfers. In addition, automated control of waste handing mechanisms and the fact that future casks are expected to be without fins (possible because of transport of older waste with less heat generation) would be expected to reduce turnaround times. Thus, transfer times given in Table 7.1 are conservative.

\section{4 cosTs}

The high-spot costs for the igloo concept, estimated in mid-1982 dollars, are given in the following subsections. A contingency of $30 \%$ is included in all costs. The costs have not been converted to a present worth basis. Bases and details of the cost estimates are given in Appendix $H$. 
TABLE 7.1. Operational Sequences in the Igloo Concept

Receive storage cask (required time: $1 \mathrm{hr}$ ) $(\mathrm{a}, \mathrm{b})$

1. Move storage cask transfer car to load/unload apron.

2. Lift storage cask onto transfer car.

Receive shipping cask and prepare both casks (required time: $2 \mathrm{hr})^{(a)}$

1. Move shipping cask transfer car to load/unload apron.

2. Lift shipping cask onto transfer car.

3. Move transfer car into decontamination and air lock chamber.

4. Clean cask exteriors as required.

5. Sample shipping cask atmosphere and equalize pressure.

6. Remove outer lids on casks.

7. Loosen fasteners on inner cask lids.

8. Mount inner lid lifting mechanisms to the inner lids.

Intercask transfer (required time: $1-4 \mathrm{hr})^{(\mathrm{a})(\mathrm{c})}$

1. Open shielding doors, move transfer car into position in the fuel transfer chamber, close shield doors.

2. Personnel evacuate the decontamination and air lock chamber.

3. Remove both cask covers and swing them aside, by the systems on board the transfer car.

4. With the transportation cask in-line with the transfer tower, horizontally index the hoist/grapple. Verify.

5. Grasp and raise the fuel assembly into the tower.

6. Move transfer car to align storage cask with the transfer tower.

7. Index the transfer tower hoist/grapple unit horizontally with fuel assembly suspended to the selected basket cavity in the storage cask.

8. Lower the fuel assembly into the basket cavity, and disconnect. the grapple.

9. Raise the hoist/grapple above the top level of the casks.

10. Repeat steps 4 to 9 until either the transportation cask is empty or the storage cask is full, or until the desired number of transfers has been completed.

11. Remotely replace the covers on both casks.

12. Open shielding doors, move transfer car into decontamination and air lock room.

Prepare for dispatch of shipping cask (required time: $6 \mathrm{hr})^{(\mathrm{a})}$

1. Survey and decontaminate.

2. Secure inner lid of shipping cask.

3. Replace and secure outer lid of shipping cask.

4. Move transfer car to load/unload apron. Load shipping cask on shipping vehicle.

5. Inspect and sign off. 
TABLE $7.1 \cdot$ (contd)

Prepare for dispatch of storage cask (required time: $6 \mathrm{hr})^{(\mathrm{a}, \mathrm{b})}$

1. Survey and decontaminate.

2. Secure inner lid of storage cask.

3. Replace and secure outer lid of storage cask.

4. Move transfer car to load/unload apron. Load storage cask onto on-site transporter.

5. Inspect and sign of $f$.

(a) Time estimates modifjed from Griffen and Spritzer (1983) by this author.

(b) These steps required only for every 3 to 24 shipping casks.

(c) Shorter times are for smal1 truck casks; longer times are for large rail casks.

\subsubsection{Design, Construction and Shakedown Costs}

The capital costs for the igloo concept were estimated to be $\$ 8.8$ million, including design and construction and the transporter for moving storage casks to the on-site storage. The costs are summarized in Table 7.2.

\subsubsection{Operating Costs}

Operation of the intercask transfer facility encompasses the steps shown in Table 7.1. From these operations, staffing requirements for the total facility were estimated by this author, and are the same as in Table 6.4 for the trench concept. This is a total of 29 staff members.

Estimates were made of staff costs (by this author) and other operating costs (see Appendix $H$ for bases). These annual costs of $\$ 2.0$ million are summarized in Table 7.3 .

\subsubsection{Relocation Costs}

The relocation costs consist of costs for disassembly, preparation for shipment, loading and unloading, and reassembly and inspection of transportable items at the new site; the nontransportable portion (concrete slabs, etc.) of the facility to be duplicated at the new site; and power and lighting costs. Freight is not included in the relocation costs, which are estimated to be $\$ 2.7$ million and are given in Table 7.4 . 
TABLE 7.2. Capital Cost Sumary for the Igloo Concept(a)

Direct Costs

Site work and concrete ${ }^{(b)}$

Building

100-ton crane

Shielding

Transfer cars

Decontamination coating (b)

Transfer equipment

Decontamination system

Change room

Electrical equipment (d)

HEPA filter system

HVAC

Control trajler

Transporter

Total direct costs

Overhead and profit (15\%)

Total construction costs

Engineering, services and procurement (10\%)

Construction management $(4 \alpha)$

Ouality assurance allowance (20\%)

Subtotal

Cont ingency $(30 \%)$

Total capital costs

Design costs $(15 \%$ of total capital) $(e)$

Total Design and Construction Costs (rounded)
$1982 \$ \times 10^{3}$

NA 926 (C)

800.0

121.0

450.0

113.3

361.7

113.1

35.3

120.0

37.6

18.0

24.0

680.0

$3,800.9$

570.1

$4,371.0$

437.1

174.8

$874 . ?$

$5,857.1$

$1,757.1$

$7,614.2$

1,142

8,760

(a) From Kaiser Engineer's estimate (Reynolds 1982).

(b) Not transportable.

(c) $\mathrm{NA}=$ not applicable.

(d) One-half not transportable.

(e) Added by this author; partly included in the Kaiser Engineers estimate under engineering, services and procurement

(Reynolds 1982). 
TABLE 7.3. Operating Cost Summary for the Igloo Concept

\begin{tabular}{|c|c|}
\hline $\cos t 5$ & $1982 \$ 10^{3} / \mathrm{yr}$ \\
\hline $\begin{array}{l}\text { Operating labor cost } \\
\text { (including indirect costs) }\end{array}$ & 1,241 \\
\hline Consumables & 124.1 \\
\hline Maintenance & 152.3 \\
\hline Subtotal & $1,517.4$ \\
\hline Contingency $(30 \%)$ & 455.2 \\
\hline Total (rounded) & 1,970 \\
\hline
\end{tabular}

TABLE 7.4. Relocation Costs for Igloo Concept (a)

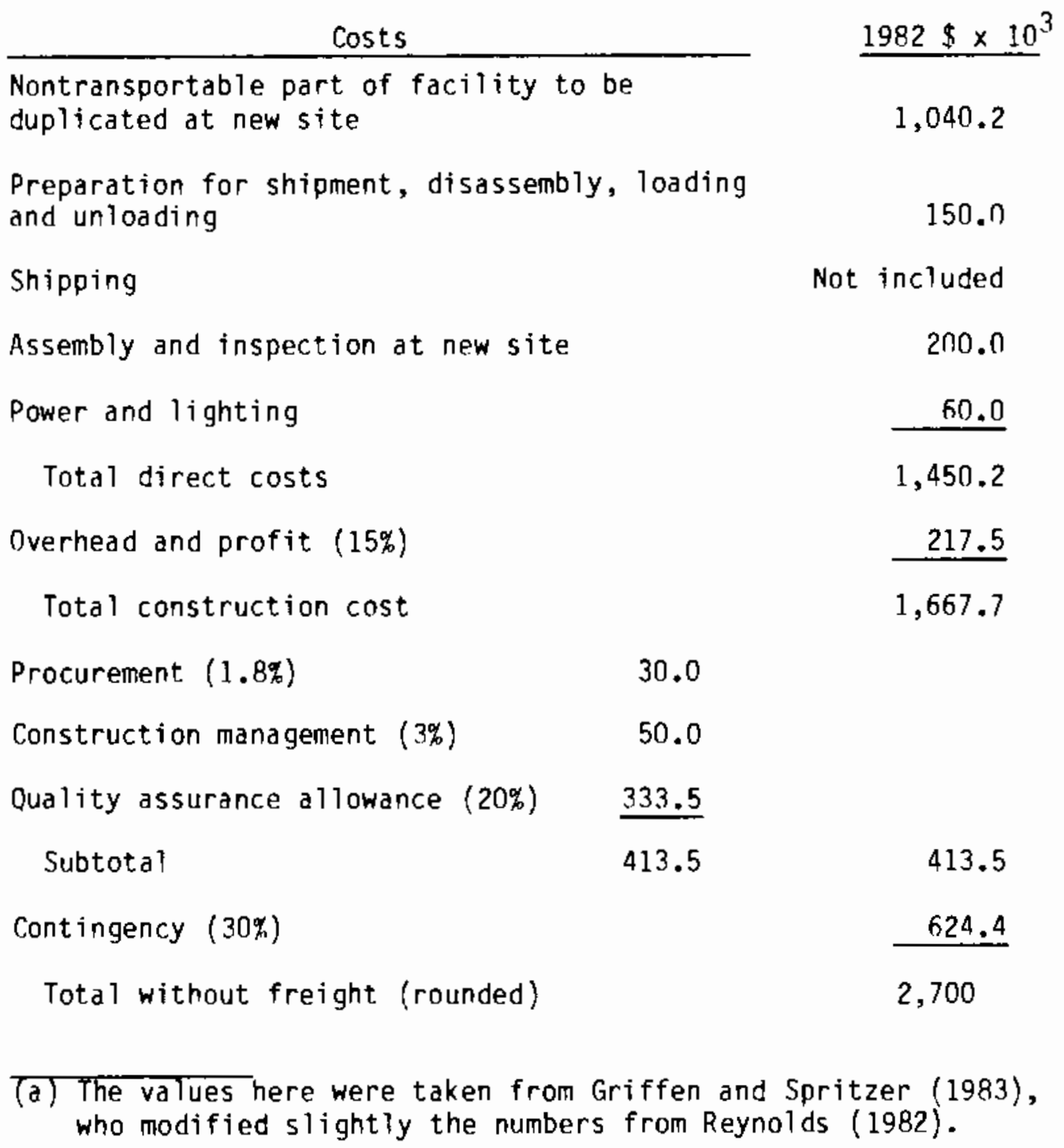




\subsection{IMPLEMENTATION SCHEDULE}

The schedule for implementation of the igloo concept for the intercask transfer equipment shown in Figure 7.2 is estimated to be 18 months after initiation of the design and construction contract.

The schedules for the design and construction phases are believed to be readily achievable because the igloo concept is of conventional design and requires only standard construction techniques. The fuel transfer equipment and controls are advanced in design and performance but are selected from standard components and require mainly that adequate lead time be given for their procurement.

It is estimated that relocation would require about 14 months, since most of the hardware and equipment would already be available. Disassembly of the existing facility would need to be phased with construction at the new location.

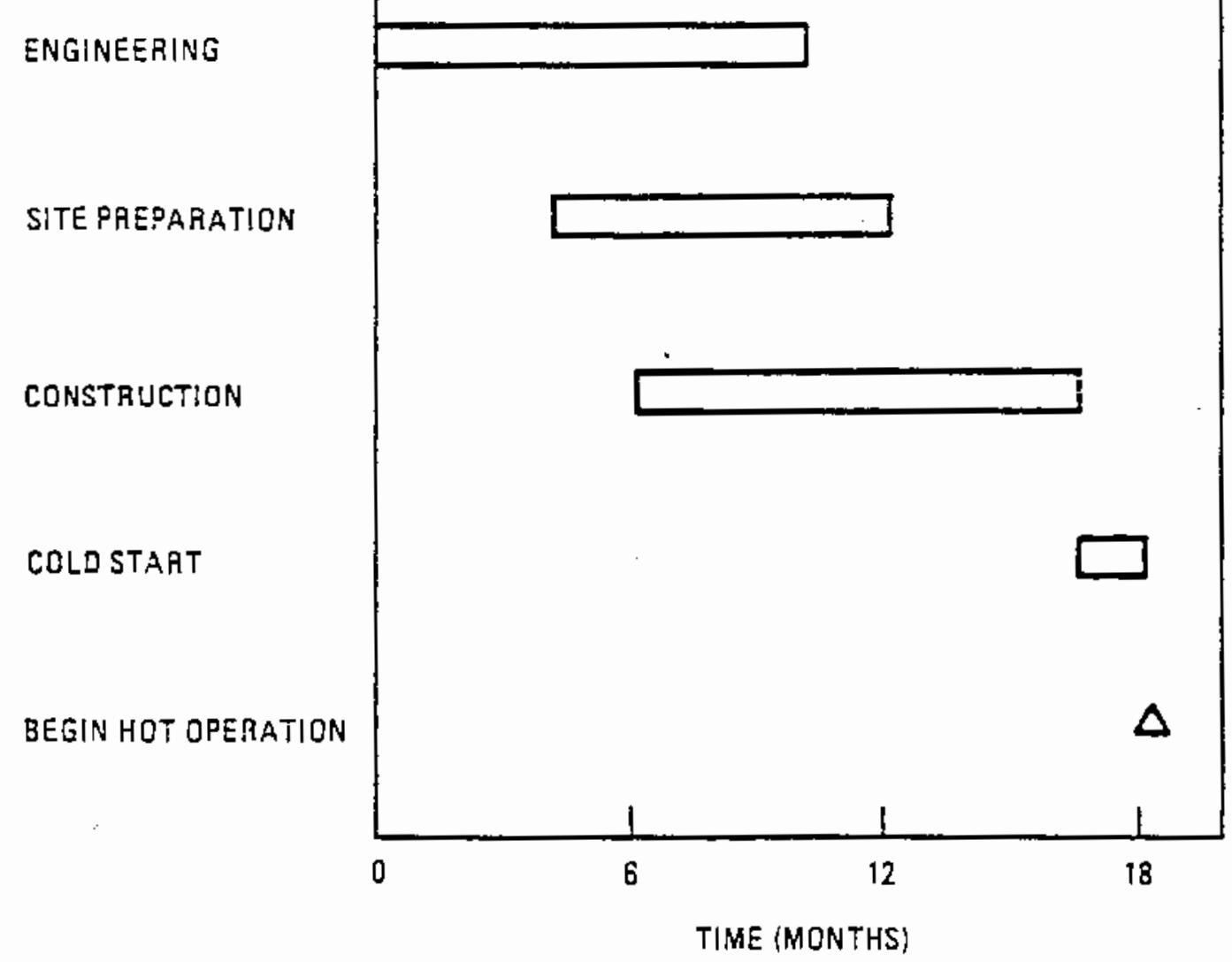

FIGURE 7.2. Implementation Schedute for Igloo Concept 


\section{REFERENCES FOR SECTION 7}

Griffin, R. and M. H. Spritzer. January 1983. Preconceptual Design of Intercask Transfer Equpment. GA Technologies, Inc., San Diego, California.

Reynolds, R. K. October 1982. Spent Fuel Transfer Facility - Concept Study. Raymond Kaiser Engineers, Oakland, California. 
APPENDIX A

GENERAL DESCRIPTION OF TRANSPORT CASKS

FOR SPENT FUEL. 


\section{TABLE A.l. General Description of Transport Casks for Spent Fuel.}

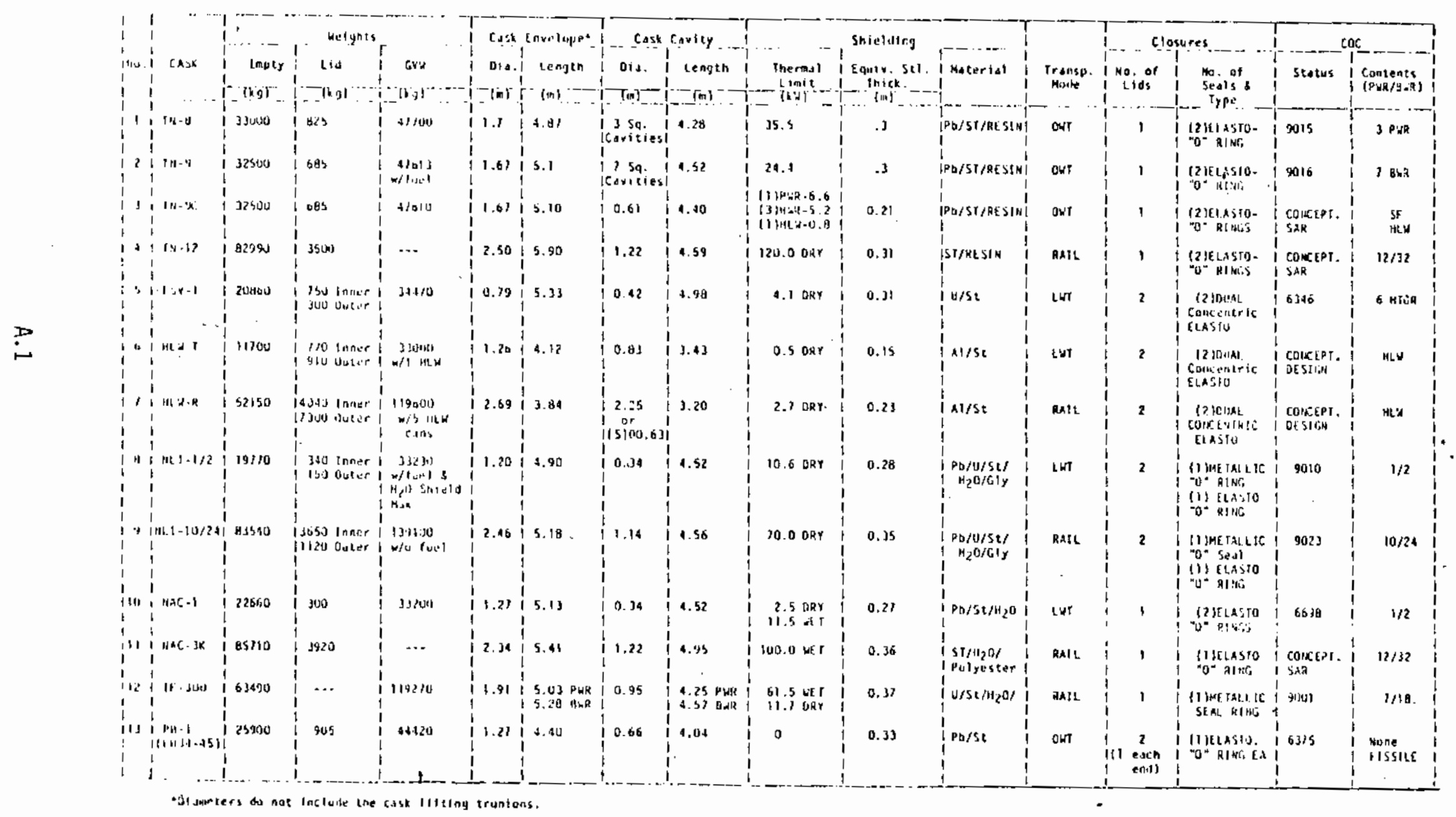




\section{REFERENCE FOR APPENDIX A}

Vigi1, M.G. and G. C. Allen. 1982. Spent Fuel and High-Level Waste Transportation Systems for DOE TEST Programs. SAND82-0329, Sandia National Laboratories, Albuquerque, New Mexico. 
APPENDIX B

REFERENCE DESCRIPTION OF METAL STORAGE CASKS 
TABLE B.1. General Description of Storage Casks (DOE 1981, Brooks and Perkins, 1982)

REA-2023

Designer/Manufacturer

Structural Material

Shielding

Cask Envelope, $(m, f t)$

Diameter

Length

Intact Fue]

Consol idated Fuel

Length

Loaded Weight, (MT)

Thermal Limit, (kW)

: $24 / 52$

$48 / 104$

$30^{(b)}$

\section{REA}

Stee 1

$11.5 \mathrm{~cm} \mathrm{~Pb}$

$5 \mathrm{~cm}$ steel

$16.5 \mathrm{~cm}$ water $/$ glycol
CASTOR-V (Band C)

GNS

Nodular cast iron

NAla

$20-24 / 50-52$

NA

PWR: $2.4(\overline{7} .8)$

BWR: $2.4(7.7)$

PWR: $4.7(15.3)$

BWR: $5.0(16.3)$

$79.6-88.6$

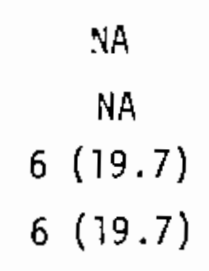

$90.9-113.6$

$45-55$

(a) $N A=$ Not Available

(b) Can be increased to $47 \mathrm{~kW}$ by addition at the storage site of special fins. 


\section{REFERENCES FOR APPENDIX B}

Brooks and Perkins/AAR Company. 1982. Dry Storage Casks for On-Site Storage of Spent Nuclear Fuel. Manufacturer's Literature, Livonia, Michigan.

U.S. Department of Energy (DOE). 1981. A Preliminary Assessment of

Alternative Dry Storage Methods for the Storage of Commercial Spent Nuclear Fue?. DOE/ET/47929-1, prepared by E. R. Johnson Associates, Inc., Reston, Virginia. 
APPENDIX C

REFERENCE DESCRIPTION OF SPENT FUEL 
TABLE C.1. General Description of Spent Fuel (E. M. Greene 1980, RHO 1978)

\begin{tabular}{|c|c|c|c|c|c|c|}
\hline & $\begin{array}{l}\text { Bare } \\
\text { PUR Fuel } \\
\text { Assembly }\end{array}$ & $\begin{array}{l}\text { Bare } \\
\text { BWR Fuel } \\
\text { Assembly }\end{array}$ & $\begin{array}{l}\text { Canistered } \\
\text { Intact PWR } \\
\text { Fuel } \\
\end{array}$ & $\begin{array}{l}\text { Canistered } \\
\text { lntact BWR } \\
\text { Fuel }\end{array}$ & $\begin{array}{l}\text { Consol idated } \\
\text { PWR Fuel }\end{array}$ & $\begin{array}{l}\text { Consolfdated } \\
\text { BWR Fuel }\end{array}$ \\
\hline Package Configuration & $\begin{array}{l}17 \times 17 \\
\text { array of } \\
\text { rods }\end{array}$ & $\begin{array}{l}8 \times 8 \\
\text { array of } \\
\text { rods }\end{array}$ & $\begin{array}{l}1 \text { assembly } \\
\text { per canister }\end{array}$ & $\begin{array}{l}3 \text { assemblies } \\
\text { per canister }\end{array}$ & $\begin{array}{l}2 \text { assemblies } \\
\text { eq. } \\
\text { canister per }\end{array}$ & $\begin{array}{l}2 \text { assemblies } \\
\text { eq. } \\
\text { canister }\end{array}$ \\
\hline Package length $(\mathrm{m}, \mathrm{ft})^{(\mathrm{b})}$ & $5.1(16.7)$ & $4.5(14.9)$ & $5.6(18.5)$ & $5.0(16.5)$ & $5.1(16.7)^{(c)}$ & $4.5(14.9)$ \\
\hline $\begin{array}{l}\text { Transverse } \\
\text { Dimensions }\left(\mathrm{cm}, i_{n}\right)\end{array}$ & $\begin{array}{l}(21.4) 8.4 \\
\text { square }\end{array}$ & $\begin{array}{l}(14.0) 5.5 \\
\text { square }\end{array}$ & $\begin{array}{l}(14.0) 35.6 \\
\text { diameter }\end{array}$ & $\begin{array}{l}(16.0) 40.6 \\
\text { diameter }\end{array}$ & $\begin{array}{l}(21.4) 8.4 \\
\text { square }\end{array}$ & $\begin{array}{l}(14.0) 5.5 \\
\text { square }\end{array}$ \\
\hline Package weight $(\mathrm{kg}, \mathrm{lb})$ & $658(1450)$ & $272(600)$ & $1450(3200)^{(d)}$ & $1735(3815)^{(d)}$ & $1500(3300)^{(e)}$ & $750(1650)^{(e)}$ \\
\hline Kg U Per Package & 460 & 180 & 460 & 540 & 920 & 360 \\
\hline $\begin{array}{l}\text { Heat Generation } \\
\text { Rate per Package } \\
\text { (kW)(f) }\end{array}$ & 0.89 & 0.28 & 0.89 & 0.84 & 1.78 & 0.56 \\
\hline
\end{tabular}

(a) Fuel elements are disassembled and only the fuel rods are placed in canisters.

(b) Includes lifting device on top of fuel elements or canisters.

(c) Oimensions of the consolidated fuel canister are assumed to be approximately the same as the dimensions of the intact fuel assembly.

(d) Includes the weight of the fuel element; canister, and internal support structure within the canister.

(e) Weights are approximate. Based on canisters weighing about $500 \mathrm{~kg}$ for PWR fuel and $300 \mathrm{~kg}$ for BWR fuel.

(f) Based on heat generation rate of L.WR spent fuel five years after reactor discharge. Assumed irradiation levels are 33,000 MWd/HTU and 26,762 MWd/MTU for PWR and BWR assemblies, respectively. 


\section{REFERENCES FOR APPENDIX C}

Greene, E. M. 1980. Spent Fuel Data for Waste Storage Programs. HEDL-TME-79-20, Hanford Engineering Development Laboratory, Richland, Washington.

Rockwe11 Hanford Operations (RHO). 1978. Spent Fuel Receiving and Packaging Facility - Conceptual Design Report. RHO-CD-506, Richland, Washington. 


\section{APPENDIX D}

REFERENCE HIGH LEVEL WASTE CANISTER

AND ITS CONTENTS 
TABLE D.]. Design Parameters of a Reference HLW Canister
and Its Contents(a)

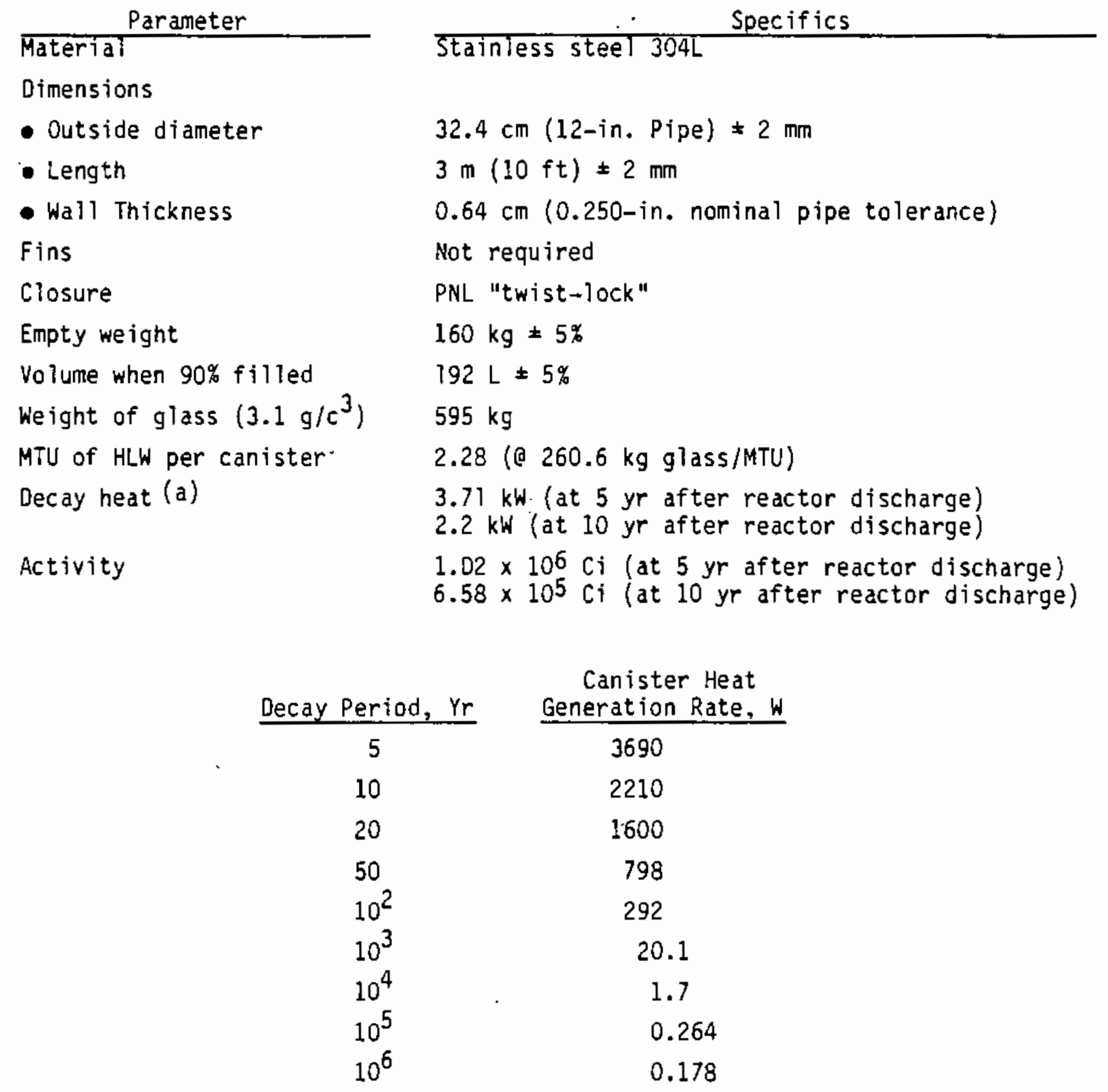

(a) Taken from Slate 1981. 


\section{REFERENCE FOR APPENDIX D}

Slate, S.C., W. A. Ross, and W. L. Partain. 1981. Reference Commercial HighLevel Waste Glass and Canister Definition. PNL-3838, Pacific Northwest

Laboratory, Richland, Washington. 
APPENDIX E

COST ESTIMATING DETAILS AND BASES

FOR THE TURNTABLE CONCEPT 
APPENOIX E

COST ESTIMATING DETAILS AND BASES

FחR THE TURNTABLE CONCEPT

This appendix provides the details of the high-spot cost estimates for the turntable concept. The capital costs include the costs of the fuel transfer facility and all necessary equipment, including indirect costs and contingency. Cost exclusions are land acquisition, owner-furnished equipment, construction financing, off-site improvements, taxes, startups, casks, and Nuclear Regutatory Commission licensing. All costs are in 1982 dollars. A contingency of $30 \%$ has been added which reflects the conceptual engineering and cost information available.

The capital costs were estimated by Kaiser Engineers-Hanford (Howard 1982) and modified slightly by GA Technologies (Griffin 1983) to make them consistent with other estimates provided by GA on two other concepts (given in Appendices $F$ and $G$ ). The Kaiser Engineers-Hanford estimates are included as pages E.2 through E.6. The detailed work sheets by GA Technologies are included as pages E.7 through E.9. Total capital costs are estimated to be $\$ 10.99$ million, not including design costs, using the bases given in Appendix G.2. Operating and maintenance and relocation costs were developed by this author. 


\section{KAISER \\ ENGINEERS \\ HANFDRD}

KAISER ENGIHEEAS HANFORD COMPANY

POST OEFICE BOX BgO

AICHLAND. WASHINGTON 99352

August 18, 1982

K. J. Schneider

PNL/Energy Systems

SIGMA 4/102

Subject: Spent Fuel Transport Equipment A97489/B116A0

This letter transmits to you our estimate on the above project. We estimate the construction cost to be 3.3 million with engineering of 1.025 million and contingency of $2.175 \mathrm{million}$ for a total project of 6.5 mil1ion.

Other costs to consider are escalation and conceptual design. Escalation is not considered as a calender schedule was not avajlable. Our estimate of conceptual design is shown on the Sumsnary Sheet, Sheet 1 of 3, for information only and is not included in the total project cost.

If we can be of further service, please contact me.

Sincerely,

$m 9 \mathrm{ktz}$

M. J. Howard

Sr. Estimator

MJH:ad

At tachment

CC: M. E. Otson, PIL

G. P. Osborne, KEH

File 


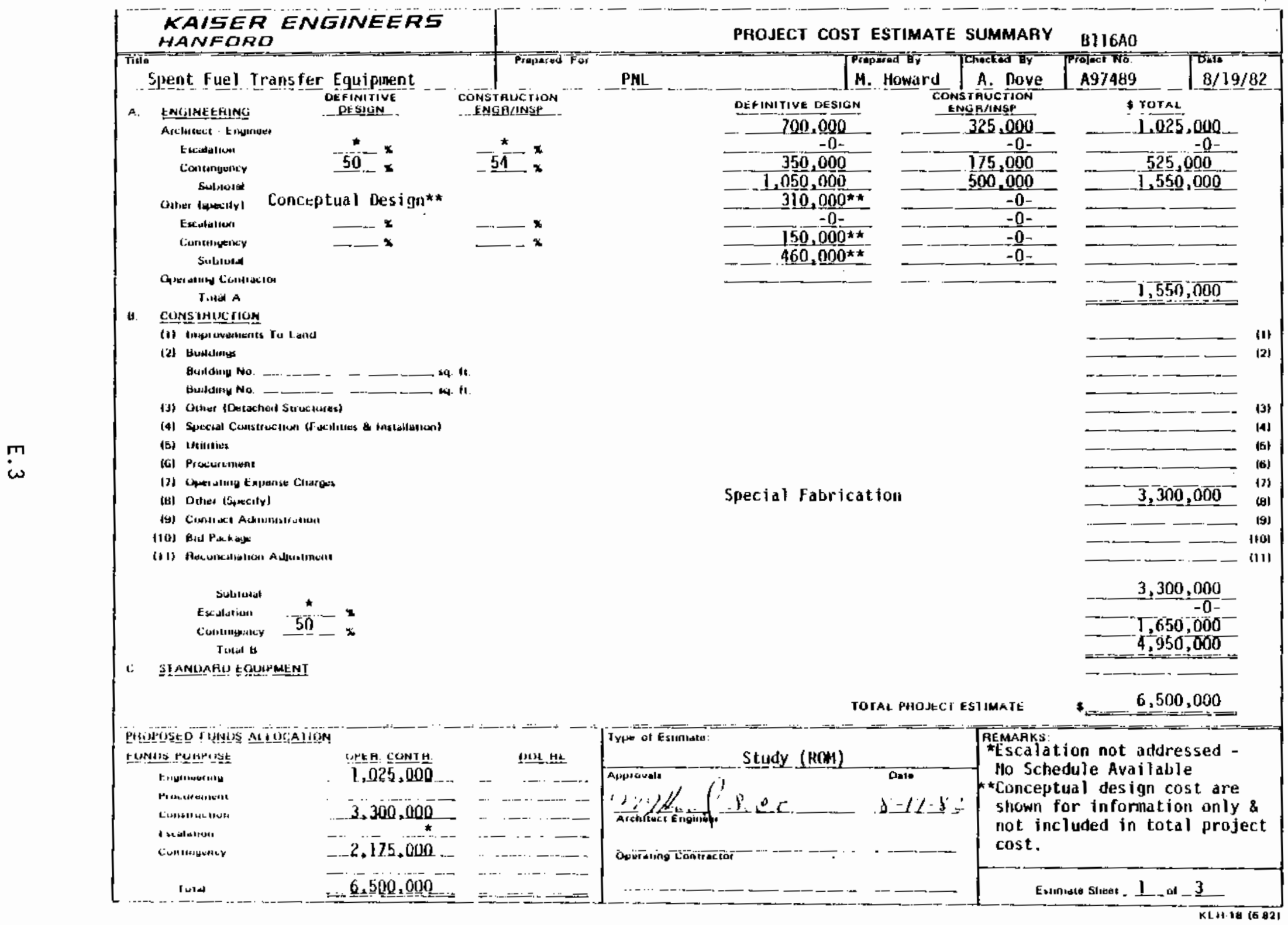




\section{KAISER}

ENGINEERS

HANFORD

August 19, 1982

KAI\$ER ENGINEERS HANFORO COMPANY

DOST OFFICE BOX BOS

AICHLANO. MASHINGTON A9JSZ

\section{Estimate Basis}

Title: Spent Fuel Transfer Equioment

KEH Job \#: B116AO

Client Project $\frac{\|}{\pi}$ : $\quad$ A97489

1. DOCUMENTS AND DRALINISS

DOCIMENTS: Draft copy of request for bids to design and fabricate equipment to transfer spent nuclear fue? between transport and storage cask, dated August 13, 1982

2. REMARKS

A. This estimate was made from the document listed above.

B. The following assumptions were made:

7. The unit is $25^{\prime}$ in diameter, the bottom section is $25^{\prime}$ tall. The lift section is an additional $25^{\prime}$ high.

2. The turntable must support approximately 100 ton.

3. The wall will be fabricated with a stainiess inner and outer wall, 4-1/2" lead shielding and $6^{\prime \prime}$ of borated polyethelene shieiding.

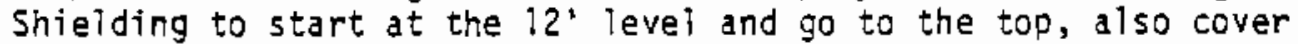
the top and the whole lift cylinder.

4. The three enciosed cubicle will have periscopes and CCTY's.

5. The unit will have HEPA filtered air flow with a slight negative pressure (maintained by air flow).

6. The unit will be able to be disassembied for transportation.

7. The unit will be assembled and acceotance test at the installation site.

9. All facilities, mounting pads, etc to be provided by the purchaser. AODITIONAL REMARXS

9. This estimate was done as a brief overview due to tine constraints. (16 manhours funded)

10. The engineering was done from a manloading concept allowino a number of drawings times engineering hours to produce them.

11. Contingency was taken at 50\% due to the unknowns involved.

12. Escalation was not addressed as a schedule with a calender time frame was not available.

MJH:ad

E.4 


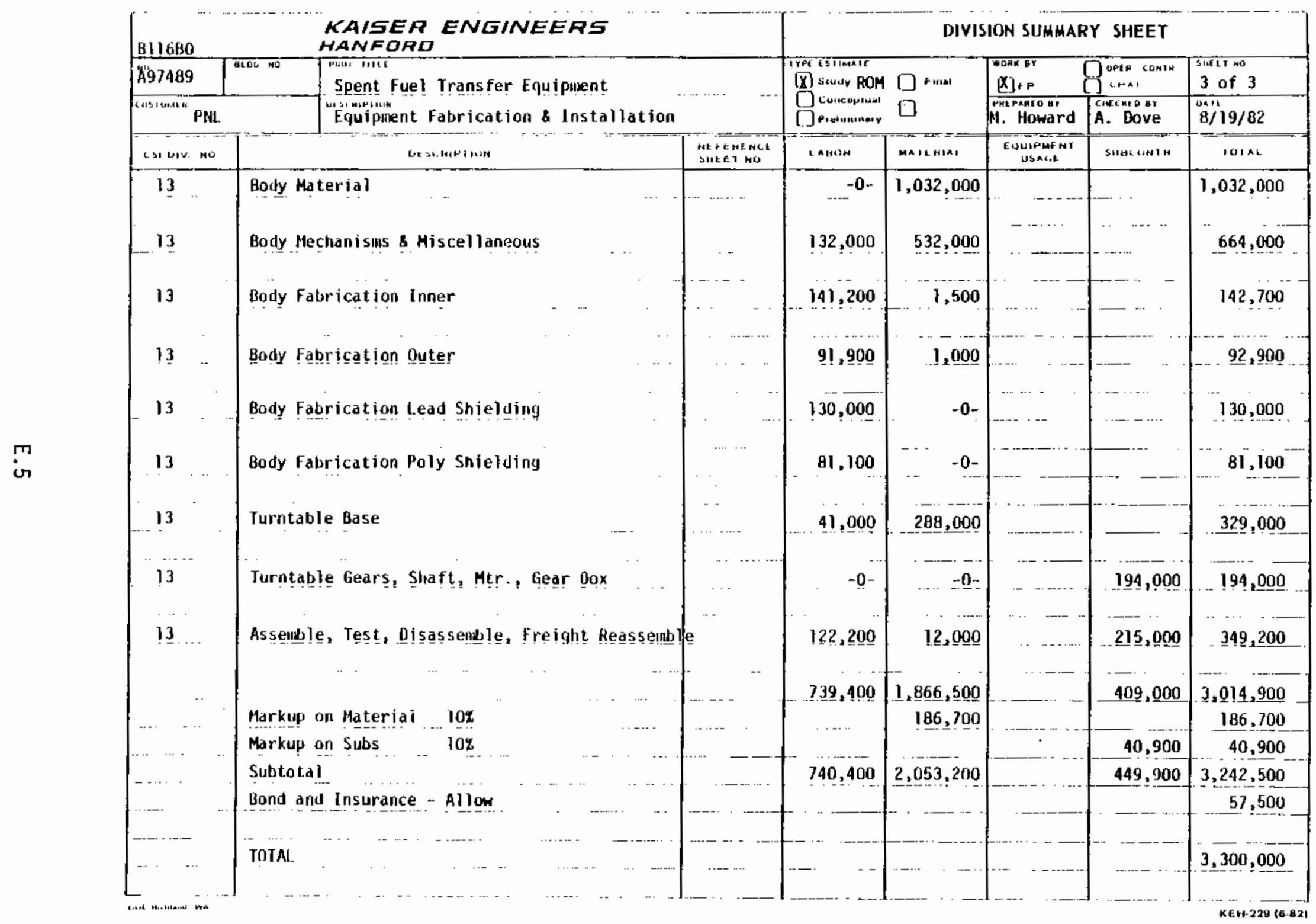




\section{ATTACHMENT 2}

Review of the Schedule for Spent Fuel Transport Equipment

A review of the PNL proposed schedule was made. (See Figure 3, Design and Fabrication Schedule for Spent Fuel Transfer Equipment, Draft Copy dated August 13, 1982).

The PNiL schedule shows 32 months total. Our review indicated that the schedule will probably be 41 months; seven (7) months for conceptual design and approval; 11 months for definitive design and approva1; 15 months for fabrication, with testing, shipping and final installation and acceptance making up the remainder of the $4 i$ months.

MJH:ad

$8 / 19 / 82$ 


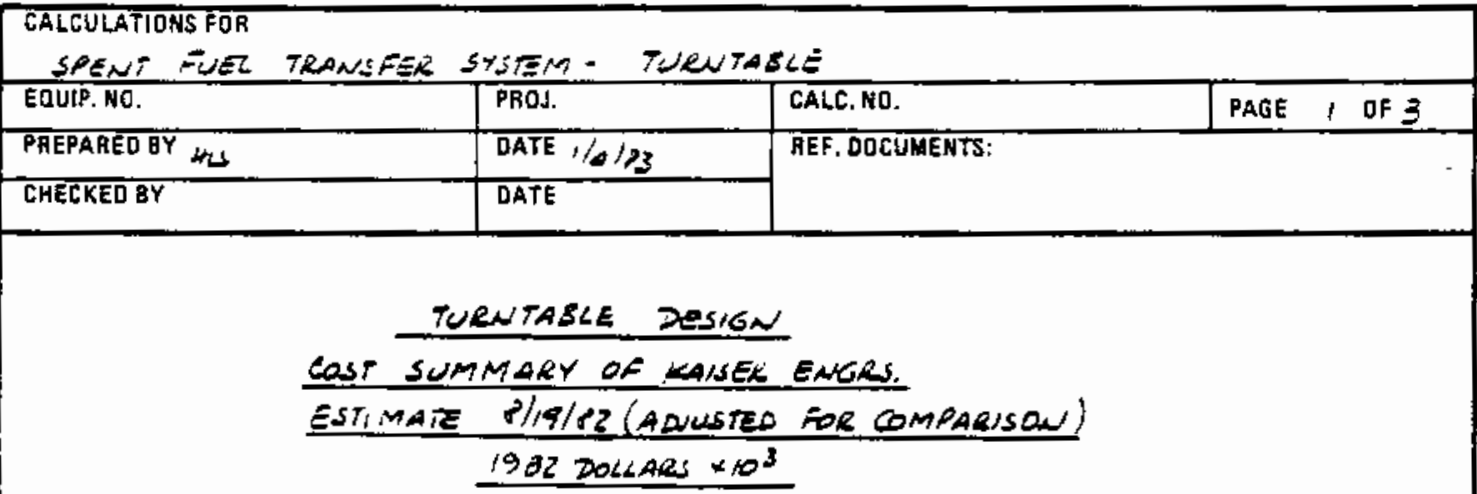

7

$$
8
$$

DIRECT COST

1. SITEWORK I CONCESTE

2. 3UILDING

3. 100 TON GRANE

4. SWIELONG

5. TRANSFER CART

6 Decour coATNG

7. TRANSFER EQUIPT.

8. DECONTAMINATION SYSTEM

9 . Change Rom

10. ELECTULAL EQUIPT.

11. HEPA FILTER IYST.

12. $\angle Y A G$

3. CONTROL TRAILER

D TRANSTORTR

$$
\begin{aligned}
& \text { TOTAL DIRECT COSTS } \\
& 0.4 \text { \& PROAIT (15\%) }
\end{aligned}
$$

TOTAK CONSTRUCTION COSTS

ENGRG. SERVILES I PROCUREMENT (10\%)

CONSTR. MANAGEMENT $(4 \%)$

QA ALLOWANCE (20\%)

SUE - TOTAC

SONTINGENCY (30\%)

Total capitite couta
TOTAL $\times 10^{3}$

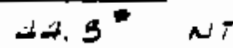
$950.6^{*}$ $300.0^{\circ}$

1.531 .1

NA

N. A

1.187 .0

$113.1=$

$35.3^{\circ}$

$120.0^{\circ} 1 / 2 N T$

inCL

INCG.

$24.0^{*}$ $630.0^{*}$

$5,485.9$

322.9

6.308 .8

630.9

252.4

1261,8

0.453 .9

2.536 .2

$10,990.1$

- added to kaiser encleg. 3use estimate gligir fuz dost compinison' NT. NOT TRANSPOETABLE 


\begin{tabular}{|c|c|c|c|}
\hline EQUIP. NO. & PROJ. & CALC. NO. & PAGE 2 OF 3 \\
\hline PHEPARED BY HIS & DATE $1 / 4 / 83$ & \multirow{2}{*}{\multicolumn{2}{|c|}{ REF. DOCUMENTS: }} \\
\hline CHECKED BY & DATE & & \\
\hline
\end{tabular}

1

3

4

5

6

7

8

9

19

11

12

13

14

15

16

17

18

19

20

21

22

23

24

25

26

27

28

29

30

31

32

33

34

35

36
1. 5ITWORK I CONCRETE

BUILDING FOUNDATON INCL. TURNTABLE SUPPORT

$65^{\prime} \times 65^{\prime}+z^{\prime}$ THICK $* 320 \mathrm{CY}$ e $140 \% \mathrm{HY}$

2. BUILDING

BUTLER BUILDING SIZE $65^{\circ} \times 65^{\circ} \times 90^{\prime}$ WIGH

$=380.250 \mathrm{FT}^{3}$ e $250 \mathrm{~d} / \mathrm{F}^{3}$ (INCL. HYAC, GIGHT/NG,

Gen'erar services)

3. $10070 \mathrm{~m}$ CRANE

4. SHIELDING

\begin{tabular}{lr} 
BODY LEAD SHIELDWE & 130.0 \\
BODY FOLY SHIELDIAC & 81.1 \\
BODY MATERIAC & 1.032 .0 \\
BODY FABRICATION INNER & 142.7 \\
BODY FABRICATION OUTEE & 92.9 \\
ASSEMBLY (15\% OE 349.2) & $\Omega 2.4$ \\
\cline { 2 - 2 } & 1.531 .1
\end{tabular}

5. TRAUSFER CAR

6. DECON COATING

7. TRANSFER EQUIPMENT

BODY MECWANISMS ; MISC.

TUENTABLE BASE

664.0

TURNTABLE GETR, SHAFT ETE.
329.0

194.0
Totar $* 10^{5}$

$44^{*}+e^{*}$

$950.6^{*}$

$300.2^{*}$
1.531 .1

$N, A$.

N.4.

E. 8 
CALCULATION SHEET

CALCULATIONS FOR

SPENT FUEL TRANSFEL FAGLIT. TURNTABLE

\begin{tabular}{|l|l|l|l|}
\hline EQUIP. NO. & PROJ. & CALC. NO. & PAGE 3 OF 3 \\
\hline PAEPARED BY HSS & DATE $1 / 5 / 83$ & REF. DOCUMENTS: & \\
\cline { 1 - 2 } CHECKED BY & DATE &
\end{tabular}

2. DECONTAMINATION SYSTEM

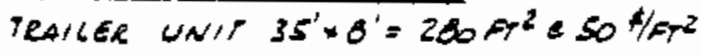

$\frac{0}{0+2}+10^{3}$

PIPING I FITTINGS

14.0

PUMRS, BDILER, HTR., TANKS, FILTER, MONTORS ETR.

12.1

TOTAC

$\frac{37.0}{113.1}$

9. CWANGE ROOM

TRAILER UNIT 35':8'

14.0

EMERGENGY SHOWER

2.5

DISPOSEC / LANDOEY FACILITY

8.0

HOLDINE TANK (1600 GR.)

2.8

AIX LOCK ENTRANCE

TOTAC

$\frac{5.0}{35.3}$

10. ELESTRICA EQUIPMENT (WAFF TRAMSPORTALLE)

POWEL \& LIGHTING DISTRIBUTION \& CONTECLS

$120.0^{2}$

11. HEPA FILTER SYSTEM

INGL. WITH TRANSFER EQUPMENT

12. $H V A C$

INCL. WITH ZUILDING COSTS

13. CONTRAL TRAILER

TRAILER UNIT $35^{\prime} \times O^{\prime}$

CONTROL CONSOLE

CONTROUS I SNITH GEHR INCL W/ELECTRICAL EOUITT. Totak

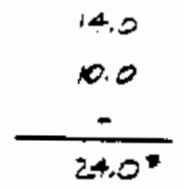

14. TRANSPOETER

STORAGE CASE TRANSPOETER INLL. ENGRL. I TESTING

$680.0^{*}$ 


\section{REFERENCES FOR APPENDIX $E$}

Griffin, R. and M. H. Spritzer. January 1983. Preconceptual Design of Intercask Transfer Equipment. GA Technologies, Inc., San Diego, CaTifornia.

Howard, M. J., Kaiser, Engineers-Hanford, letter to K. J. Schneider, PNL, August 18, 1982 (included in this Appendix). 
APPENDIX F

COST ESTIMATING DETAILS AND BASES

FOR THE SHUTTLE CONCEPT 


\section{COST ESTIMATING DETAILS ANO BASES FOR THE SHUTTLE CONCEPT}

This appendix provides the details of the high-spot cost estimates for the shuttle concept. The capital costs include the costs of the fuel transfer facility and all necessary equipment, including direct costs and contingency. Cost exclusions are land aquisition, owner-furnished equipment, construction financing, off-site improvements, taxes, startups, casks, and Nuclear Regulatory Commission licensing. All costs are in 1982 dollars. A contingency of $30 \%$ has been added, which reflects the conceptual engineering and cost information available.

\section{F.1 CAPITAL COSTS}

These and the other costs were estimated by Griffin and Spritzer (1983). The specific bases and work sheets are included in Section F.3. Bases not included therein are the same as in Appendix G.l.

\section{F.1 OPERATING ANN MAINTENANCE AND RELOCATION COSTS}

The bases for operating and maintenance costs are given in Appendix G.2. The work sheets for these costs for the shuttle concept are given in Appendix F.3. The work sheets for relocation costs of the shutt?e concepts are also given in Appendix F.3.

F.3 COST ESTIMATING BASES AND WORK SHEETS

The bases and work sheets used by Griffin and Spritzer (1983) are reproduced here as Appendix F.3. Bases not given here are the same as in Appendix G. 
APPENDIX F.3

\begin{tabular}{ll} 
Cost Estimating Bases and Worksheets & $540: 83:$ CED:09 \\
\hline
\end{tabular}

5.3 EOUIPMENT \& FACILITY COSTS-SHUTILE CONCEPT

5.3 .1 SUMMABY

The methods and assumptions for the shuttle concept cost estimate are the same as described in Section 4.3 for the trench concept. Costs are based on take-offs from the conceptual engineering Drawing 4506007 and concept descriptions. A sumary of the costs is shown on Table 5.3.1.

\section{3 .2 CAPITAL COSTS}

The cost basis of the capital costs is the same as in Section 4.3.2.

\subsection{OPERATINC \& MAINTENANCE COSTS}

A sumary of the shuttle concept operating \& Malntenance costs is shown on Table 5.3.2. The cost basts is the same as shown in Section 4.3.3.

5.3 .4 BELOCATION COSTS

A simmary of the relocation costs for the shuttle concept facility is shown on Table 5.3.3. The cost basis is the same as in Section 4.3.4. 


\section{TABLE 5.3.1 \\ SHUTTRE CONCEPT \\ COST SUMMARY \\ SPENT FUET TRANSEER EACII TTY \& DOUIPMENT \\ 1982 DOLLARS $\times 10^{3}$}

DIRECT COSTS

1. Sitework \& Concrete

2. Building

3. 100 Ton Crane

4. Shielding

5. Transfer Cars

6. Decon Coating

7. Transfer Equipont

8. Decontamination System

9. Change Room

10. Electrical Equipment

11. HEPA F1lter Systen

12. HVAC

13. Control Ta1ler

14. Transporter

Total D1rect Costs

0.H. \& Profit (15k)

Total Construction Cost

Engrg. Services \& Procurement (10s)

Constr. Management (4\$)

QA Allowance (208)

Subtotal

Contingency (30\%)

Total Capital Costs
$\operatorname{ToTal} \times 10^{3}$

58.8

NT

515.3

800.0

473.1

500.0

N.A.

$1,215.0$

88.0

35.3

120.0

$1 / 2 \mathrm{NT}$

24.0

INCL.

24.0

680.0

$4,533.5$

680.0

$5,213.5$

521.4

208.5

1.042 .7

$6,986.1$

$2,095.8$

9.081 .9

NI = Not Transportable

$$
\text { F. } 3
$$


GA 269 (REV. 4/B2)

CALCULATION SHEET

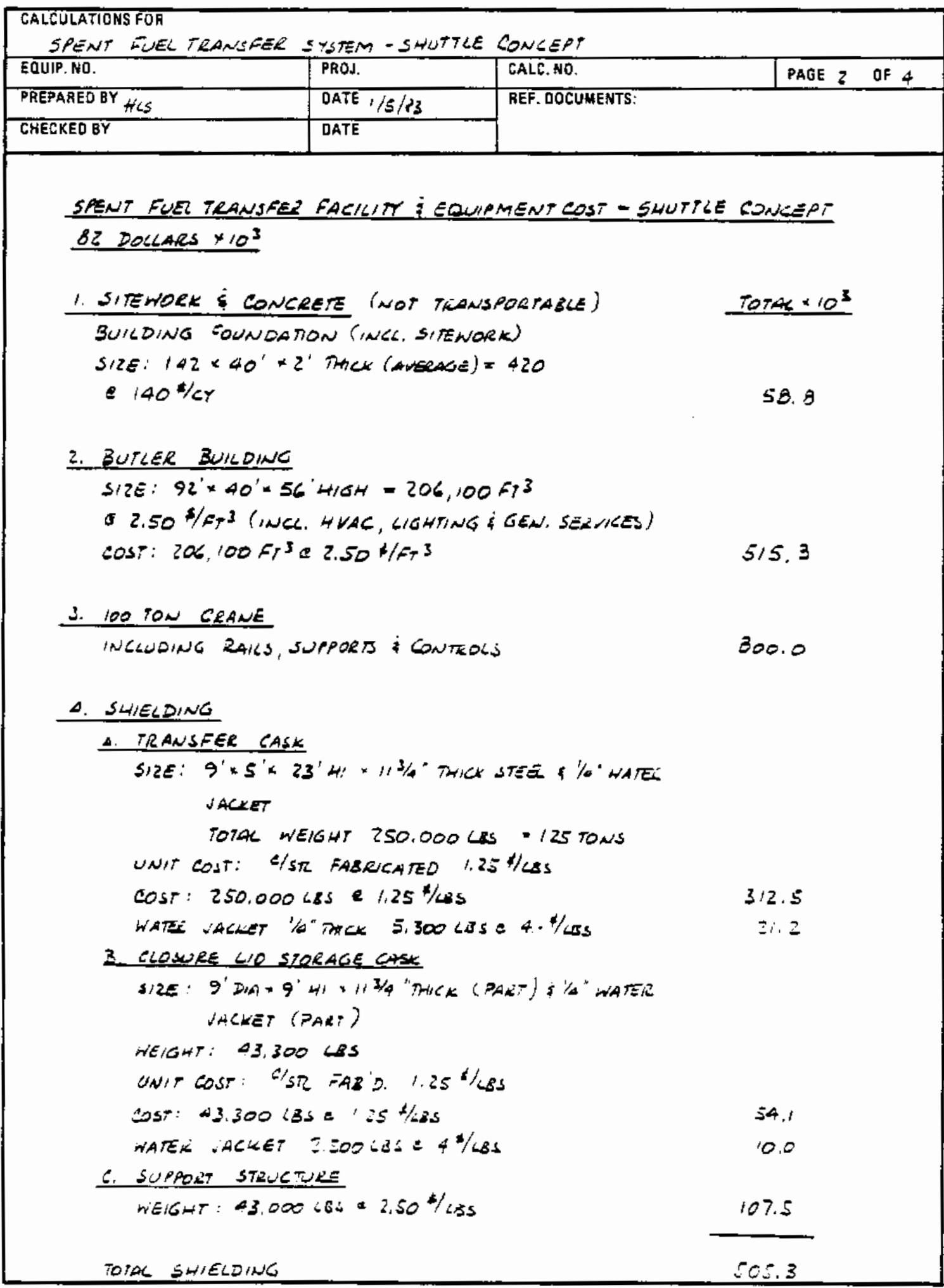

F.4 


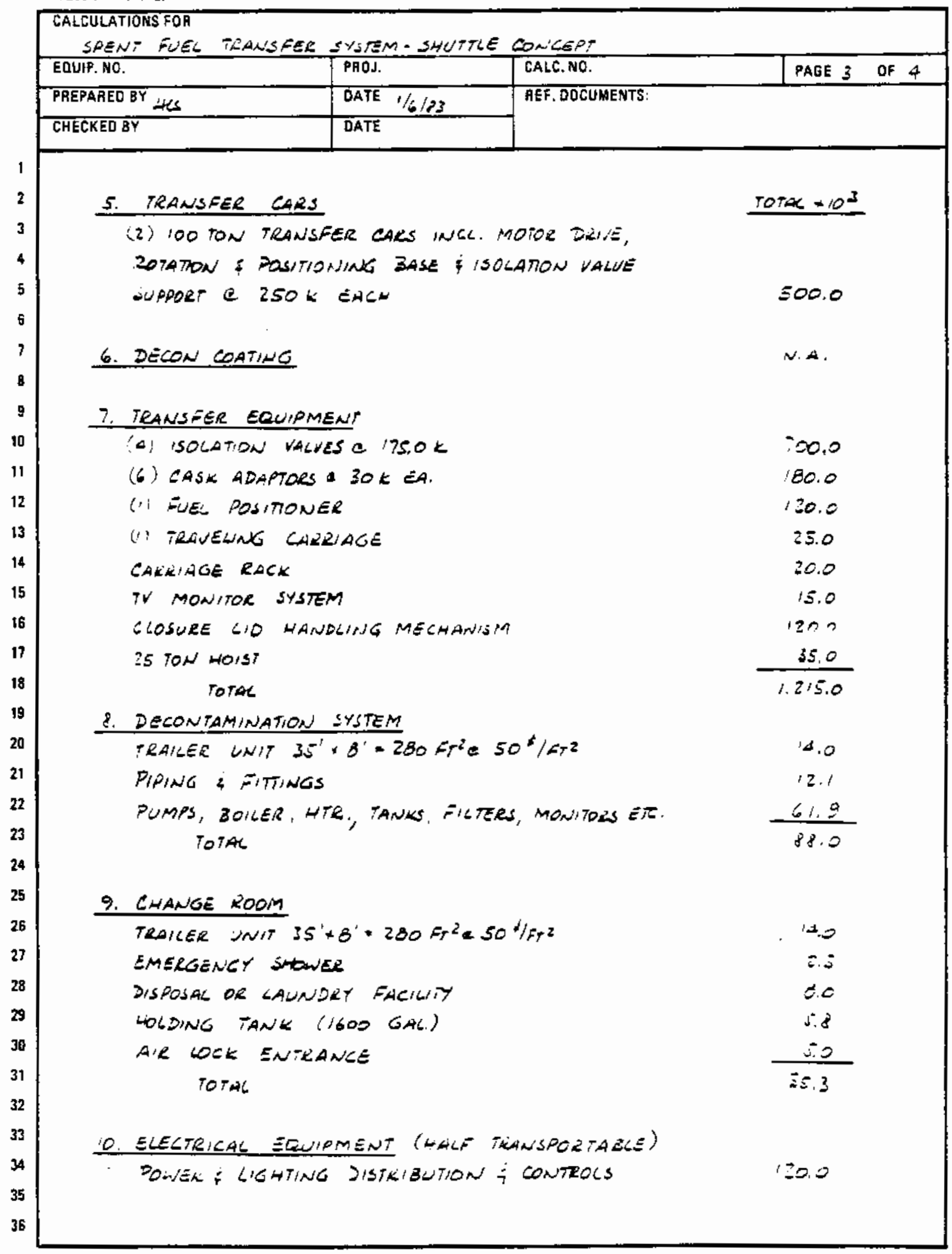




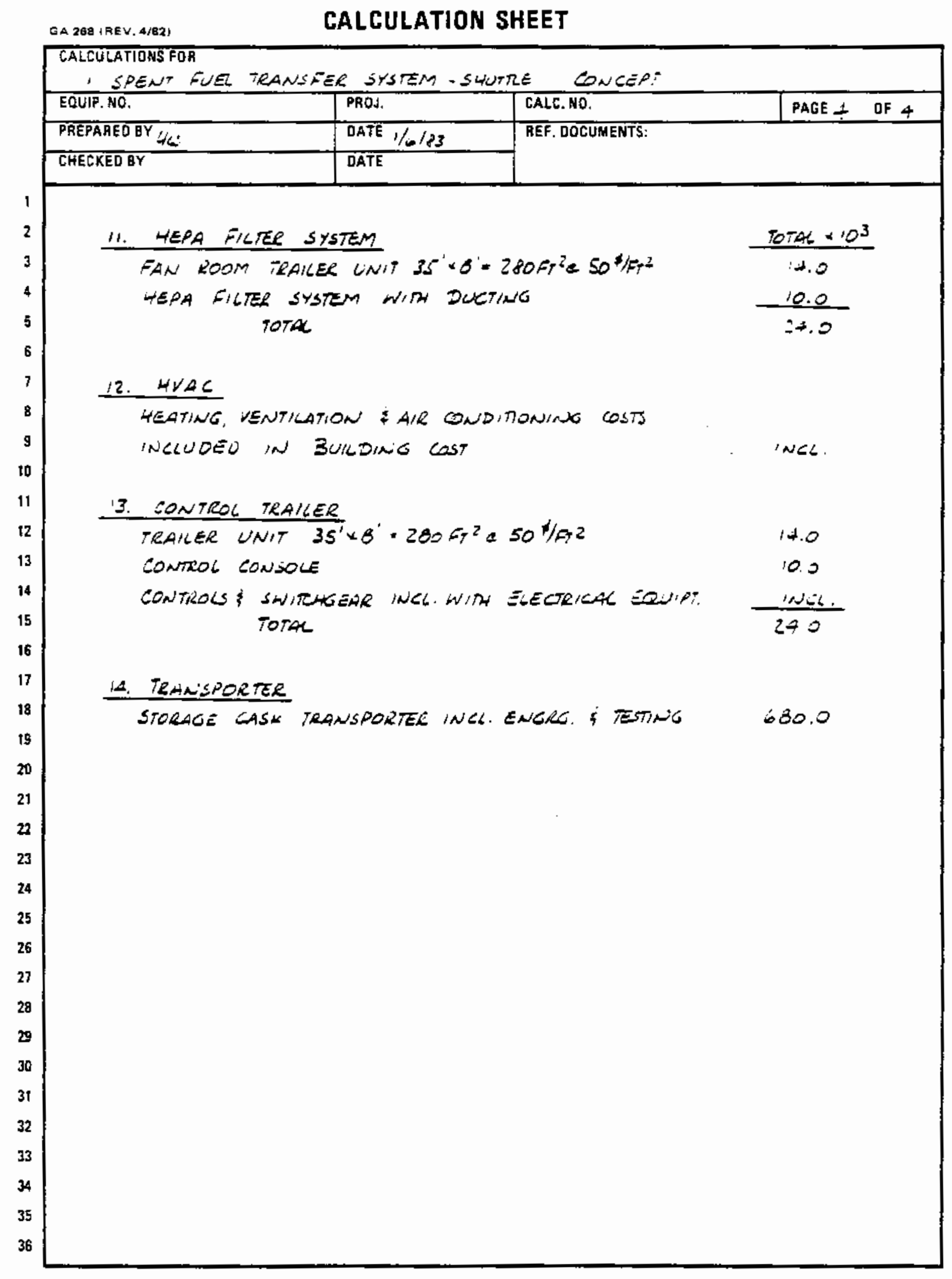


GA 2G0 \{AEV, 4/92)

CALCULATION SHEET

CALCULATIONS FOT

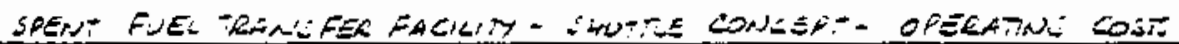

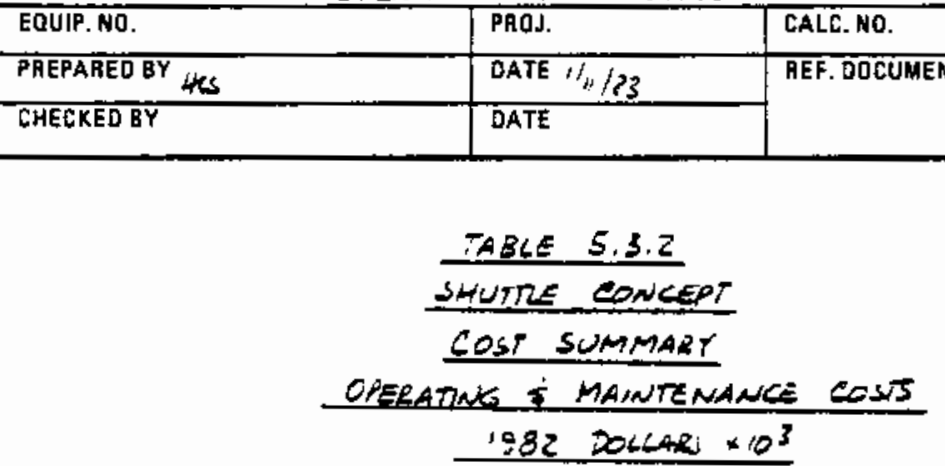

DESRRIPTION

1. coerating labor cost (incl. indirects)

2. Consumazles

3. MAINTE'ANCE

SUE. TOTAK

CONTINGENGY $(30 \%)$

TOTAL

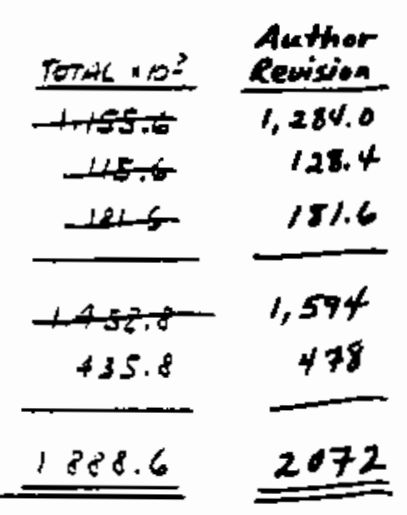

F.7 


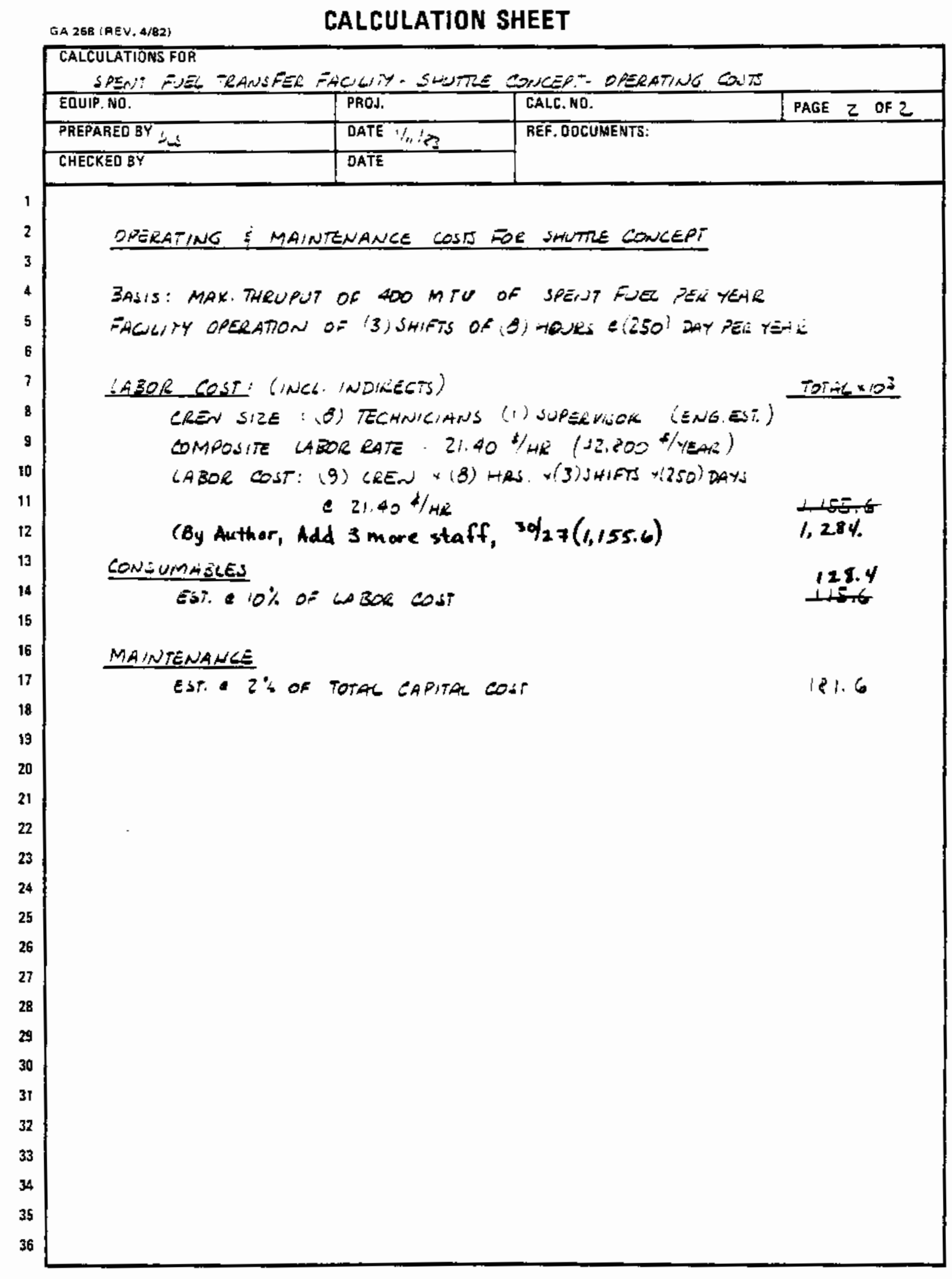

F.8 


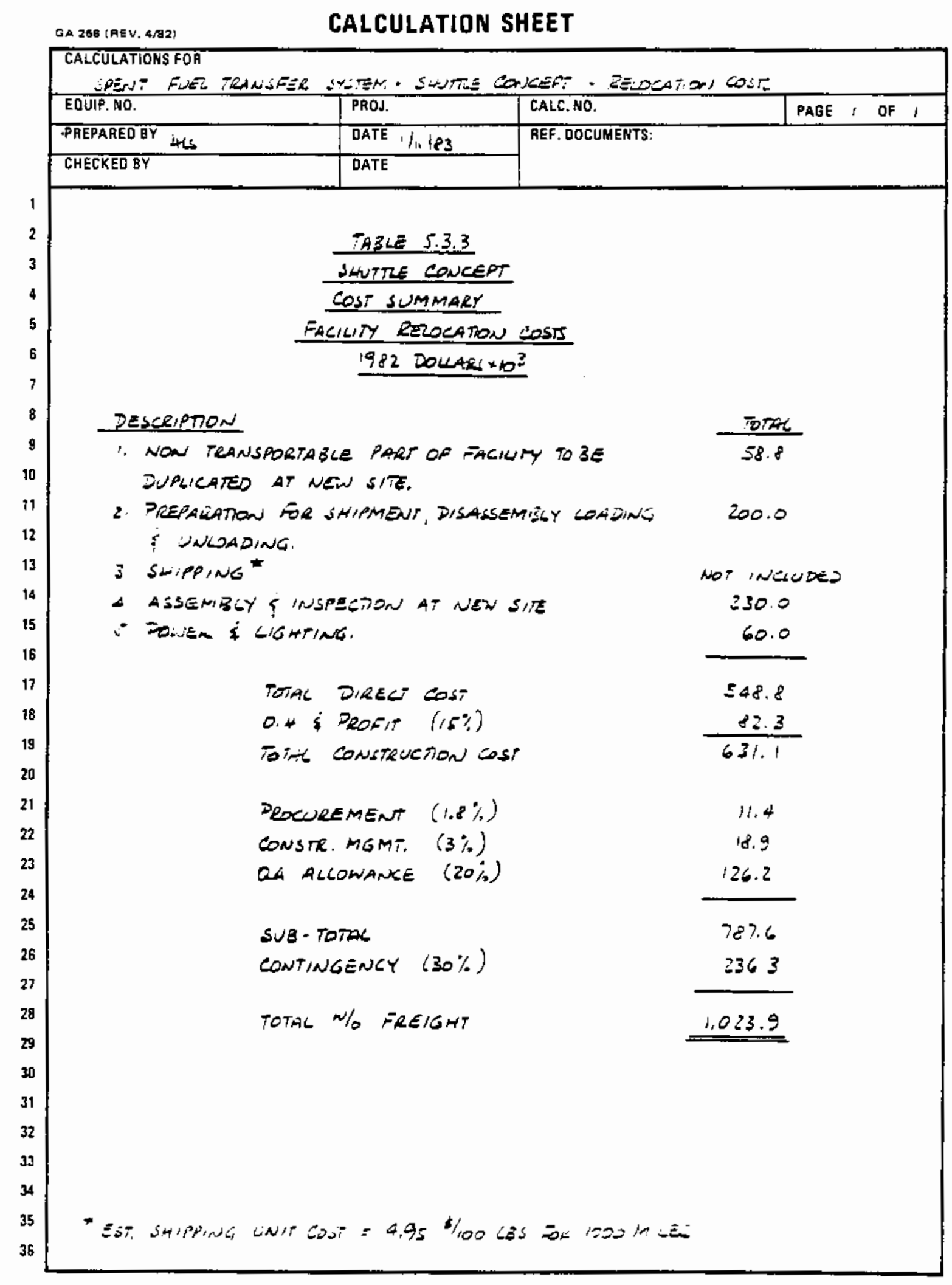


REFERENCE FOR APPENDIX F

Griffin, R and M. H. Spritzer. January 1983. Preconceptual Design of

Intercask Transfer Equipment. GA Technologies, Inc., San Diego, California.

F. 10 
APPENDIX G

COST ESTIMATING DETAILS AND BASES

FOR THE TRENCH CONCEPT 
APPENDIX G

COST ESTIMATING DETAILS AND BASES

FOR THE TRENCH CONCEPT

This appendix describes the methods and assumptions used in the high-spot cost estimates for the trench concept. The capital costs include the costs of the fuel transfer facility and all necessary equipment, including indirect costs and contingency. Cost exclusions are land acquisition, owner-furnished equipment, construction financing, off-site improvements, taxes, startups, Casks, and Nuclear Regulatory Commission licensing. All costs are in 1982 dollars. A contingency of $30 \%$ has been added which reflects the conceptual engineering and cost information available.

\section{G.1 CAPITAL COSTS}

Capital costs were estimated by Griffin and Spritzer (1983). The following subsections summarize that work.

Sitework and Concrete. The costs for site work and concrete are based on quantity take-offs from the conceptual trench concept drawing (Figure 6.1). A GA in-house developed unit cost was applied. This unit cost includes site preparation (clearing, excavation, fine grading, and installation of rail lines) and placement of concrete including materials and labor.

Building Costs. The building costs are based on a Butler-type building. The unit cost was applied to the total enclosed building volume including materials, erection labor, heating, ventilation and air conditioning (HVAC), and other services (water, lights, etc.).

Shielding. The costs of high-density shielding for the transfer chamber bigh-density concrete shielding costs are based on concrete unit costs including steel frame, concrete casting, and erection labor.

Transfer Cars. The rough-order-of-magnitude (ROM) estimates for costs for the transfer cars and storage cask transporters are based on estimates of similar equipment. The costs include cars, concrete shielding, and drive motors. 
Decontamination Coating. The cost for decontamination coating for the transfer chamber, transfer pit, and decontamination pit was estimated using Kaiser Engineers' unit costs for the igloo concept (Reynolds 1982).

Dther Equipment Costs. The costs for equipment typical to all concepts are based on Reynolds (1982). These include the 100-Mg crane, decontamination system, change room, electrical equipment, HEPA filter system, control trajler, and transporter.

Design Costs. The costs for design are taken to be $15 \%$ of the total construction costs, including contingency.

Total Design and Construction Costs. The total design and construction costs include total direct construction costs, indirect costs, and contingency. The construction costs consist of estimated total direct cost plus overhead and profit. The indirect costs of engineering services and procurement, construction management, and quality assurance allowance are percentages of the total construction cost. A contingency was added to all direct and indirect construction costs. The total costs then included the design costs as a percentage of the total construction costs (see prior item).

\section{G.2 OPERATING AND MAINTENANCE ANO RELOCATION COSTS}

The operating and maintenance costs are based on a maximum spent fuel throughput of $400 \mathrm{Mg}$. This requires 250 days/year operation with three shifts of eight hours. Labor costs are based on a composite labor rate. The cost of consumables was estimated using a percentage of the labor cost. The maintenance costs are based on a percentage of the total facility cost.

\section{G.3 CDST ESTIMATING BASES AND WORK SHEETS}

The bases and work sheets by Griffin and Spritzer (1983) to estimate capital, operating and relocation costs are reproduced in the subsequent pages. 
IAIERNAL CORRESPORDENCE

\begin{tabular}{|c|c|c|c|}
\hline FROA & H. L. Schuster & $\begin{array}{l}\text { IN REPLI } \\
\text { RERER TO }\end{array}$ & $\begin{array}{l}540: 83: \text { CED:09 } \\
80 / 1\end{array}$ \\
\hline 10 & D. W. Ketchen & DATE & $1 / 12 / 83$ \\
\hline
\end{tabular}

SUBJECT Spent Fuel Transfer Facil1ty, RFE 12203

\section{GFNERAL}

The estimates for capital costs, relocation costs and operation and wintenance costs for the trench and shuttle concepts were prepared in response to RFE 12203.

These costs and cost comparisons with (2) Kalser Englneering estimates are part of a study for Battelle Pacific Northwest Laboratories (PNL).

\section{ESTIMATE BASIS}

The estimate bas1s, methods and assumptions are described in Section $4.3,5.3$ and 7.2 of this costing report. Costs are "rough order of wagnitude" due to conceptual drawings and preliminary systems descriptions available for the estimate. A $30 \%$ contingency has been added to all costs.

\section{EEES AND INDTRECTS}

The fee, overhead and Indirect costs added to the direct costs correspond to the percentages established in the Kalser Engineer estimate $\$ 81202-340$ for the Iglo concept. It was was agreed to use these percentages to enable cost comparisons of all concepts.
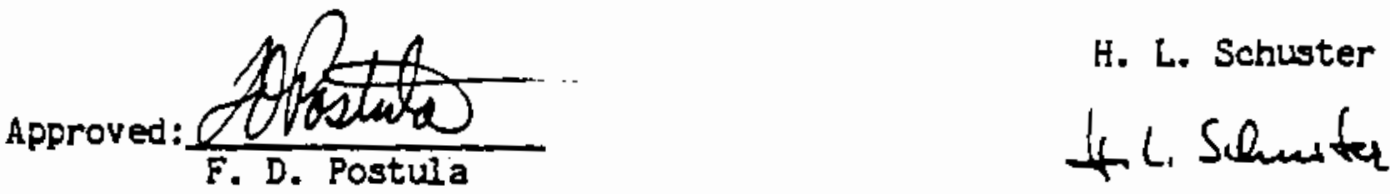

HLS:nj

Att.

cc: R. E. Field

R. Griffin

D. L. Sonn

M. H. Spritzer

$P$. Yensuang 
$540: 83:$ CED:09

$80 / 21 / 12 / 83$

\section{EUET TRANSEER SYSTEY \\ TRENCH CONCEPT \\ RFE \$2203}

\subsection{EOULPMENT AND EACIIITY COSTS - TRENCH CONCEPT}

\section{3 .1 SUMUARY}

This section describes the methods and assumptions used in the cost estimate. The capital costs include the costs of the fuel transfer facility and all necessary equipont including indirects and contingency. Costs are based on conceptual engineering Drawing $\$ 5060006$ and preliminary concept descriptions. A sumary of the costs is shown on Table 4.3.1. Title I \& II preliminary design and final design are excluded from the est fmate. Other cost exclusions are: land acquisition, owner furnished equipment, construction firancing, offsite improvements, taxes, startups, casks \& NRC licensing. All costs are in 1982 dollars. A contingency of 308 thas been added reflecting the conceptual engineering and cost information avallable at the time of the cost estimate.

\subsubsection{Siteriork and Concrete}

The costs for site work and concrete are based on quantity take-offs from the conceptual trench concept draw1ng 1506006 . An in-house developed unit cost was applied. This unit cost includes site preparation (clearing, excavation, flne grading including installation of rall lines) and placement of concrete including materials and labor.

\subsubsection{Building costs}

The building costs are based on a Butler type building. The unit cost was applied to the total enclosed building volume including matertals, erection labor, heating, ventllation and air conditioning (HVAC) and other services (water, lights, etc.)

\section{3 .1 .3 Shielding}

The transfer chamber high density concrete shielding costs are based on concrete unit costs including steel frame, concrete casting and erection labor. The quantities are based on Conceptual Drauing 25006006 .

\subsubsection{Transfer Cars}

The R.0.M. estimate for costs for the transfer and storage casks transfer cars are based on estimator's experience with similar equipment. The costs include cars, concrete shielding and drive motors. 
$540: 83:$ CED:09

$80 / 3 \quad 1 / 12 / 83$

\section{3 .1 .5 Decon Coating}

The decontanination coating for the transfer chamber, transfer pit and decon pit was estinated using Kaiser Engineers unit costs from the $10 / 12 / 82$ estimate job No. $81202-340$ for the Igloo concept. The surtace area was based on take-offs from Drawing \$5060006.

\subsubsection{Qther Equipment Costs}

The costs for equipment typical to all concepts are based on Kaiser Englneers estimate of October 12, $1982 \mathrm{Job} \$ 81202-340$. These include the 100 ton crane, decon system, change room, electrical equipment, HEPA filter system, control trailer and transporter.

\section{3 .2 CARITAL COSTS}

The total capital costs include total direct construction costs, indirects and contingency. The construction costs consist of estimated total direct cost plus overhead and profit. The 1ndirect costs of englneering services and procurement, construction management and QA allowance are percentages of the total construction cost. A contingency was added to all direct and indirect construction costs. To allow a cost comparison of all concepts, the percentages of the indirect costs and contingency were taken fron the Kaiser Engineer estimate Job 81202-340 dated 10/12/82 for the Igloo concept.

\subsubsection{OPERATING AND MAINTENANCE COSTS}

The trench concept operating and maintenance costs are based on a maximum spent fuel thruput of 400 metric tons. This requires 250 day-per-year operation at (3) shifts of (8) hours. The ananpower requirements are estimated in Section 4.2.6. Labor costs are based on a composite labor rate. The cost of consunables was estimated using a percentage of the labor cost. The maintenance costs are based on a percentage of the total facility cost. A summary of the costs is shown on Table 4.3 .2 .

\subsubsection{RELOCATION COSTS}

The relocation costs consist of costs for the disassembly, preparation for shipwent, loading \& unloading, re-assembly \& inspection at the new site, and the non-transportable portion (concrete slabe, etc.) of the facility cost to be duplicated at the new site and power \& lighting. The R.O.M. estimate is based on experience with similar costs and should only be used for cost comparisons. Freight is not included in the relocation costs. A sumbary of the costs is shown on Table 4.3.3. 


\section{TABLE 4.3 .1 \\ TRENCH CONCEPT \\ COST SUMANARY \\ SPENT FUET, TRANSEER EACILITY \& BQUIPMENT \\ 1982 DOLLARS $\times 10^{3}$}

\begin{tabular}{|c|c|c|}
\hline DIRECT COSTS & TOTAL $\times 10^{3}$ & \\
\hline 1. Sitework \& Concrete & 192.2 & NT \\
\hline 2. Buflding & 873.6 & \\
\hline 3. 100 Ton Crane & 800.0 & \\
\hline 4. Shielding . & 150.0 & \\
\hline 5. Transfer Cars & 480.0 & \\
\hline 6. Decon Coating & 57.0 & NT \\
\hline 7. Transfer Equipment & 497.0 & \\
\hline 8. Decontamination System & 113.1 & \\
\hline 9. Change Room & 35.3 & \\
\hline 10. Electrical Equipnent & 120.0 & $1 / 2 N \mathrm{II}$ \\
\hline 11. HEPA Filter System & 24.0 & \\
\hline 12. HVAC (Incl. W/Building) & Incl & \\
\hline 13. Control Traller & 24.0 & \\
\hline 14. Transporter & 6. & \\
\hline Total Direct Costs & $4,046.2$ & \\
\hline O.H. \& Profft (15\%) & 606.9 & \\
\hline Total Construction Costs & $4,653.1$ & \\
\hline Engrg. Services \& Procurement (10\%) & 465.3 & \\
\hline Construction Management (47) & 186.1 & \\
\hline QA Allowance (208) & 930.6 & \\
\hline Subtotal & $6,235.1$ & \\
\hline Contingency $(30 \%)$ & 1.870 .5 & \\
\hline Total Capital Costs & 8.105 .6 & \\
\hline
\end{tabular}

$N I=$ Not Transportable

G. 6 
GA 268 ; $A E V .4 / 82$;

CALCULATION SHEET

CALCULATIONS FOA

SPENT FUEL TRANEFER DYSTEM - TRENOH CONGEPT

\begin{tabular}{|c|c|c|c|}
\hline ED̃UtF. NO. & PĀOJ. & CALC.NO. & PAGE $Z$ OF $\div$ \\
\hline PAEPAFEO EY ThA & CATE $\therefore 4$ & \multirow{2}{*}{\multicolumn{2}{|c|}{ REF. DOCUMENTS: }} \\
\hline CHECKED BY & DATE & & \\
\hline
\end{tabular}

1

4

\section{BUILDING}

SIZE: $120 \times 56 \times \sqrt{2}$ HI $=529,440$ FI 3UTLE 3UIDING

UNIT COST : $2.50 \$ / F T^{3}$ INCL. HVAC, WGHTING GENETLE SERUICES

ost: $\quad 349.4 \Delta 0 \mathrm{FT}^{3}=2.50 \% / \mathrm{FT}^{3}$

3. 100 TON 3RIDEE CRANE

INGLUDING kiAILS, SUPPOATE S DNTEOSS 300.0

4. SHIELDING

TRANSFER CHAMBER SHELDWG

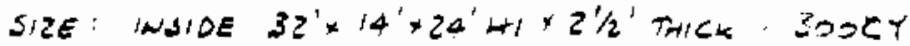

UNIT COST H DENSTY CONCEETE PRE-CHT INTO STEE FEME I $500 \%$

COST: 300 eY a soo $/ \mathrm{cy}$

150.0

5. TRANSFER CARS

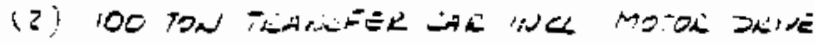
: SHELING 2 IAO K EACH

420.3 
GA 268 (REV, 4/82)

CALCULATION SHEET

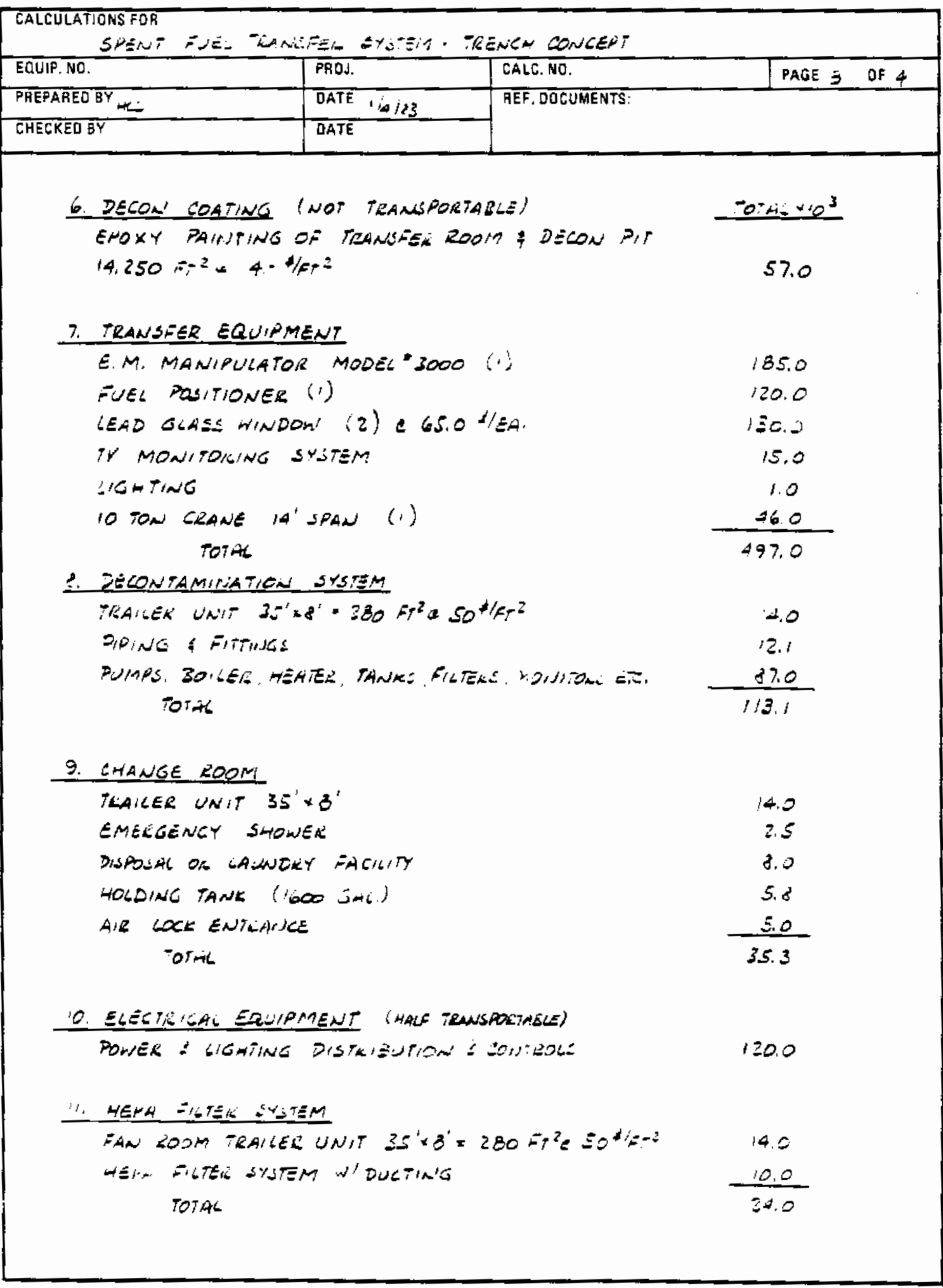

G. 8 


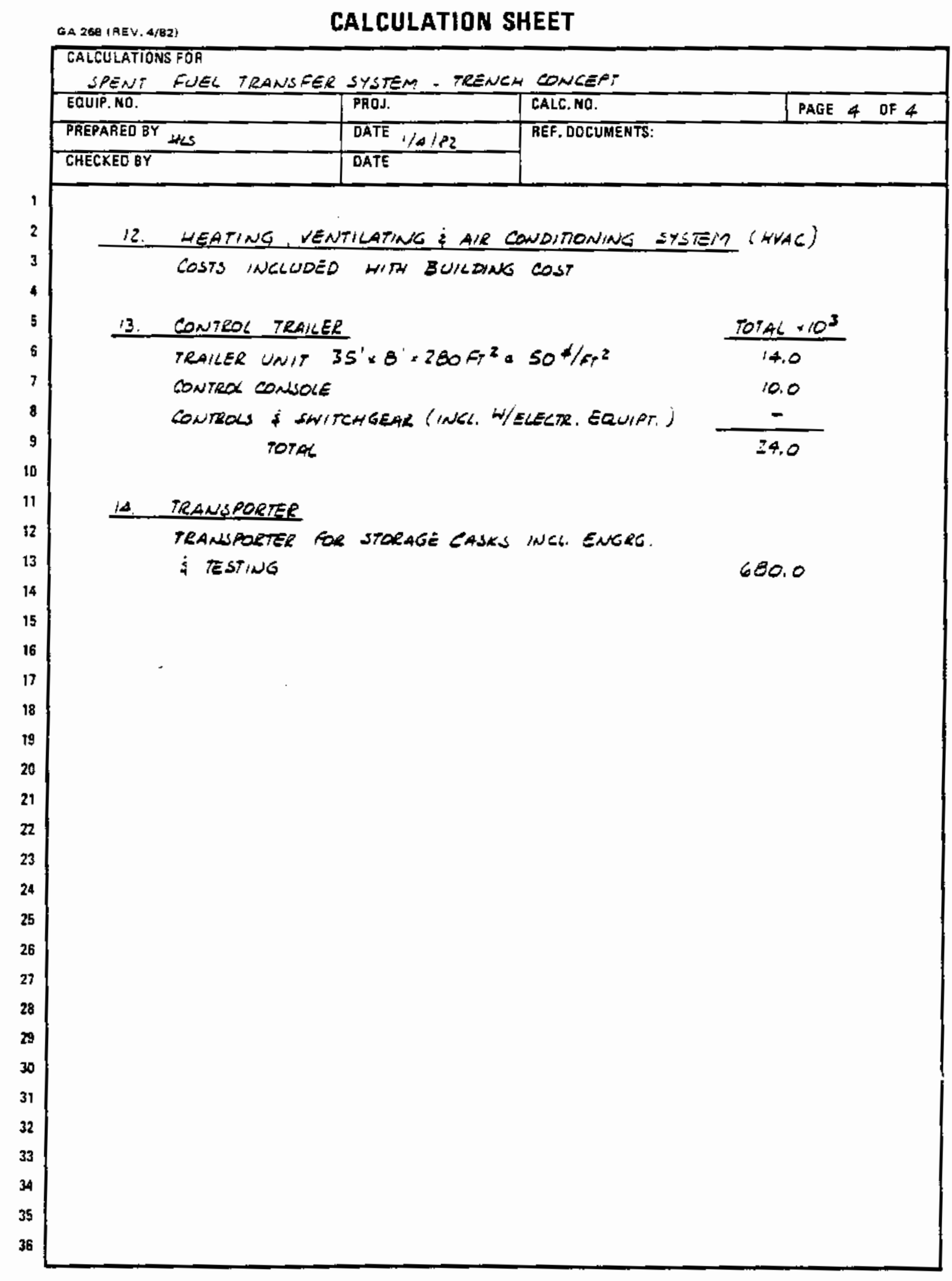

G. 9 


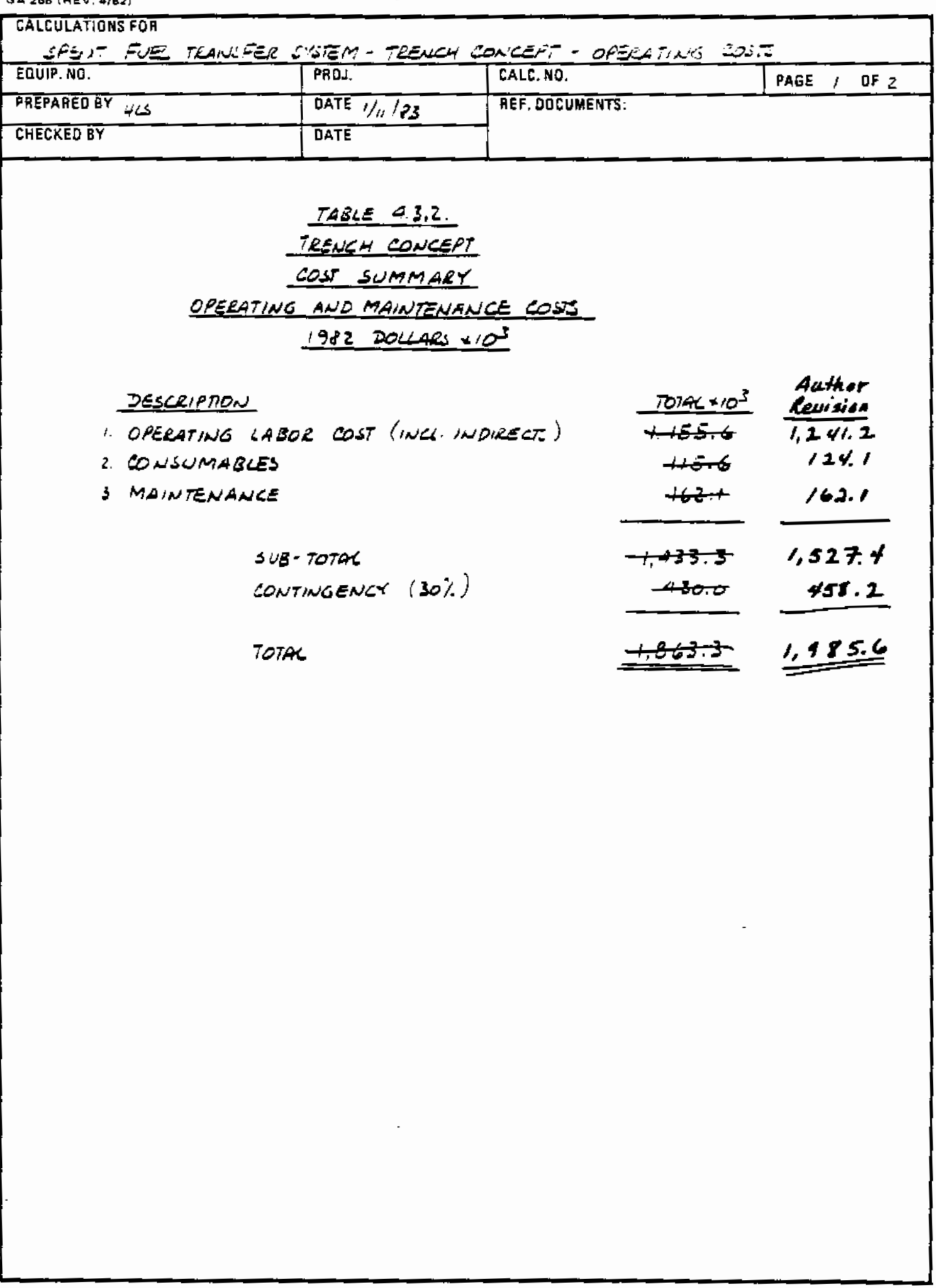

G. 10 


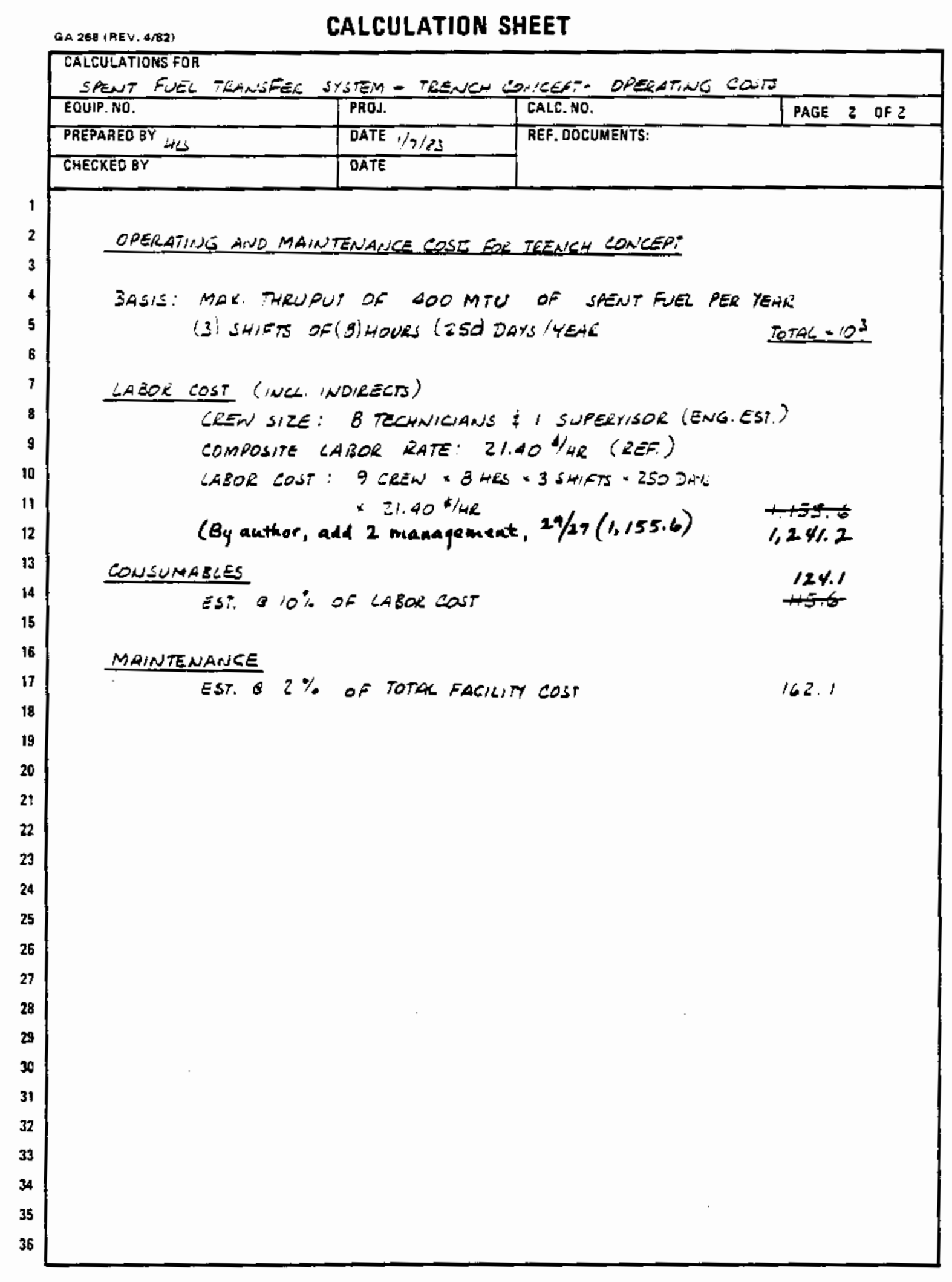

G. 11 


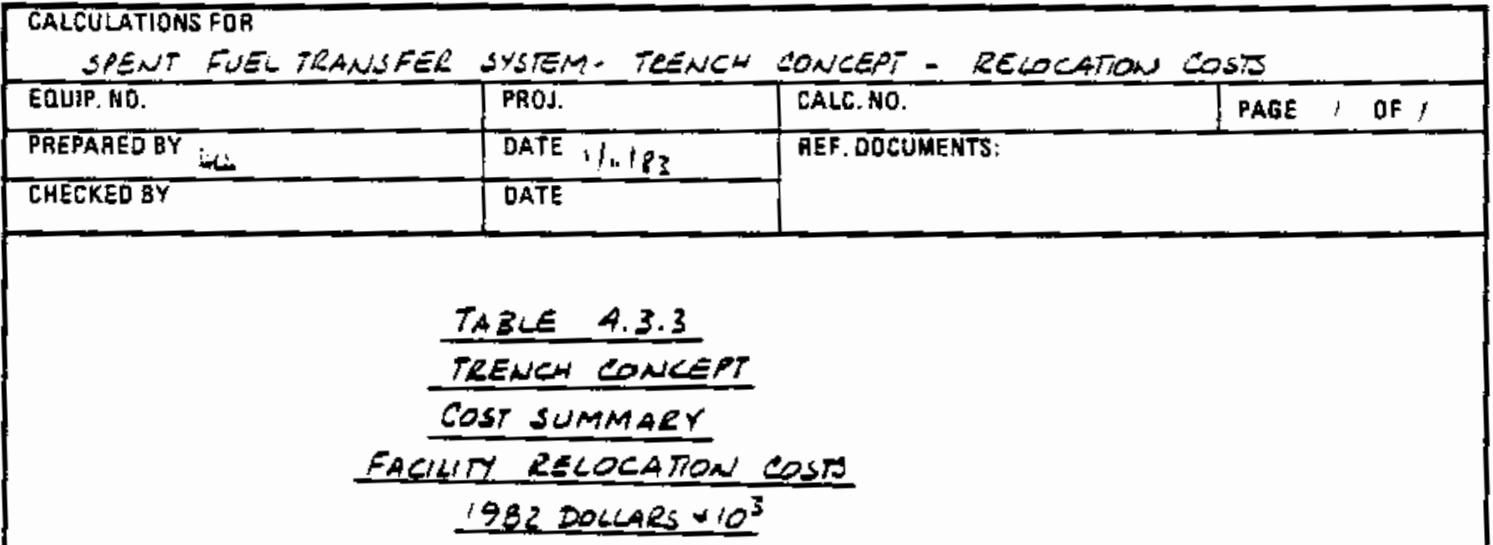

DESCRIPTION

TOTAK

1. NON TRANSPORTABLE DART OF FAcHUTY to be

DUPLICATED AT NEN SITE

249.2

2. PREPARATION FOR SHIPMENT, DISASSEMBLY, LOADING,

\& UNCOADINT

250.0

3. SHIPPING *

4. ASSEMBLY I INSPECTION AT NEN SITE

s. Boner latGating

nOT InCLUDED

300.0

60.0

TOTAR DIRECT COST

$8 \leq 9.2$

O. H. P PeOF, $(15 \%)$

total construction cost

$\frac{128.7}{988.1}$

PROCUREMENT $(1.8 \%)$

17.8

CONSTR. MGMT. ( $\$ \%$ )

29.6

QA ALONANCE (20\%)

197.6

SUB - TOTAL

1.233 .1

CONTINGENCY $(30 \%)$

3699

TOTAL W/O FREKGHT

1.603 .0

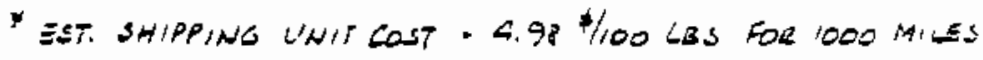




\section{REFERENCES FOR APPENDIX G}

Griffin, R. and M. H. Spritzer. January 1983. Preconceptual Design of Intercask Transfer Equipment. GA Technologies, Inc., San Diego, California.

Reynoids, R. K. October 1982. Spent Fuel Transfer Facility - Concept Study. Kaiser Engineers Report RKE 81202-340, Richland, Washington. 

APPENDIX H

COST ESTIMATING DETAILS AND BASES

FOR THE IGLOO CONCEPT 
APPENDIX H

COST ESTIMATING OETAILS ANO BASES

FOR THE IGLOO CONCEPT

This appendix provides the details of the high-spot cost estimates for the igloo concept. The capital costs include the costs of the fuel transfer facility and all necessary equipment, including indirect costs and contingency. Cost exclusions are land acquisition, owner-furnished equipment, construction financing, off-site improvements, taxes, startups, casks, and Nuclear Regulatory rommission Ticensing. All costs are in 1982 dollars. A contingency of $30 \%$ has been added which reflects the conceptual engineering and cost information available.

The capital costs were estimated by Kaiser Engineers-Hanford (Reynolds 1982) and modified slightly by GA Technologies (Griffin and Spritzer 1983) to make them consistent with other estimates provided by GA on two other concepts (given in Appendices $F$ and $G$ ). The Kaiser estimate for design costs was modified by the author of this report to make it consistent with bases for the other concepts. The Kaiser Engineers-Hanford estimates of capital and relocation costs are included as pages H.? through H.l2. The summary work sheet by GA Technologies is included as page H.1.3. Total capital costs are estimated to be $\$ 7.61 \mathrm{million}$, not including design costs.

Operating and maintenance costs were estimated by this author using the bases given in pages $G .2$ and $G .11$ of Appendix $G$. 
ESTIMATIHG DEPARTMENT

ESTIMATE REYIEW \& SIGH OFF SHEET

Project Wane: SPENT FUEL TRANSFER EOUIPMENT/FACILITY

Date: $0 C T, 12,1982$

Job No.: $81202-340$

Deseription of Work: A DRY TRANSFER CHAMBER \& EOUIPMENT

Location: RICHLAMO, WA.

FOR THE TRAYSFER OF SPEAT MUCLEAR FELL

\section{Type/Quality \\ of Estimate}

6 81d

5 Engineers

4 Definftive

3 Preliminary

2 Conceptuar

1 Magnitude

other
End Use

$\square \quad$ Study

$\square \quad$ Proposat

$\square \quad$ 8udget

$\square$ Control

$\square$ tid

(x)

\section{Target}

Guaranteed Max.

Fixed Price
Included in Estimate:

$\begin{array}{llll}\square & \text { Direct Cost } & \text { Yes } \square & \text { No } \square \\ \square & \text { CFOH \& Plant } & \text { Yes } \square \text { No } \square \\ \square & \text { ESsP } & \text { Yes } \square \text {, No } \square \\ \square & \text { CM } & \text { Yes } \square \text { No } \square \\ & \text { Escalation } & \text { Yes } \square & \text { No } \square \\ \square & \text { Contingency } & \text { Yes } \square & \text { No } \square \\ \square & \text { Fee } & \text { Yes } \square & \text { No } \square\end{array}$

Coments:

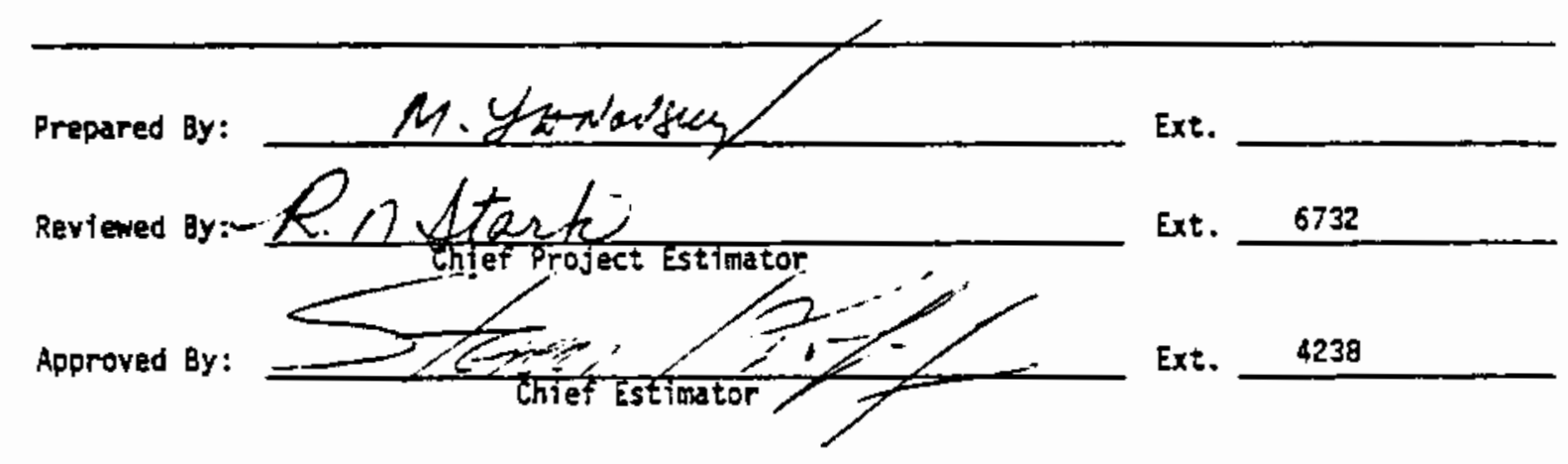

* Construction Managenent \& ESap Cost Estimates will be requited from respectfve departments. 
Job No. 81202-340

October 12, 1982

R.N. Stark

Page 1 of 2

SPENT FUEL TRANSFER EQUTPMENT/FACILITY

DEPARTMENT OF EHERGY

RICHLAND, YASHINGTON

ESTIMATE CRITERIA

FOR THE

MAGITUIE ESTIMATE

SCOPE

The scope of this estfoate covers construction of a Spent Fuel Transfer Systen.

Included are transfer chanber, decon and alr lock roon, four tralier units

and transfer car.

Purpose of this estimate is to provide a cost range for this type of schene.

DRALINGS

The estlmate is based on one prelfaifnary drawing.

SPECIFICATIONS

Mone. The hand written draft scope description was used.

ESTIMATE FORMAT

Standard RKE short forth.

QUANTITIES

Quantity take-offs where rade from the preliminary drawing. Cther quantities are based on paranetric factors and estimators judgement.

LABOR \& BURCEN

Current labor rates as published by J.A. Jones for the Hanford Area.

MATERIAL

Pricing was based on budget quotations and from in house information.

\section{SALES TAX}

Excluded.

EQUIPMENT LSAGE

Inciuded in unit costs.

H. 3 
Job Mo. 81202-340

October 12, 1982

R.A. Stark

Page 2 of

\section{SIB CONTRACT}

Although certain ftens would be subcontracted, all work in the estimate is based on a general contractor performing the construction.

EQUI PIENT

Equipuent costs used based on in-house data.

OVERHEAD I PROFIT

Contractor's overhead and proftt is $15 \%$.

INDIRECT COSTS

Ineluded separately are cost for EStP, CM and QA.

ESCALATIOH

Excluded.

CONSTRUCTION SCHEDULE

None.

COST EXCLLLSIONS

1. Land Acquistition

2. Owner Fumfshed Equipment

3. Construction Financing

4. Offsite Iaprovements

5. Transfer Crane

6. Rafl cars

7. Taxes

g. Startups

9. Shipping Casks and Storage Casks

10. NRC Licensing

11. Transporter. 


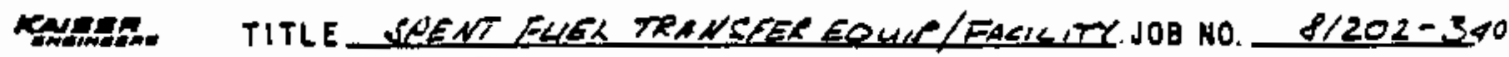

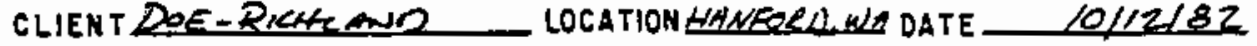
SUBJECT

BY. My

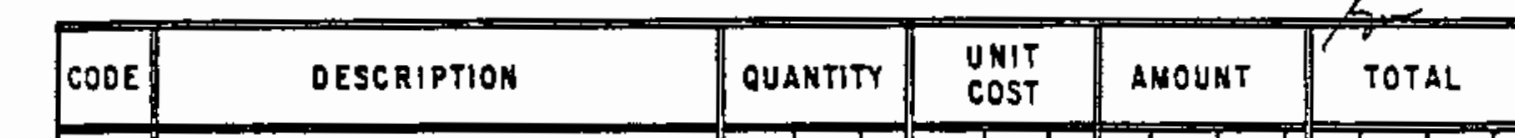

1

3

34

35

36

37

38

39

40

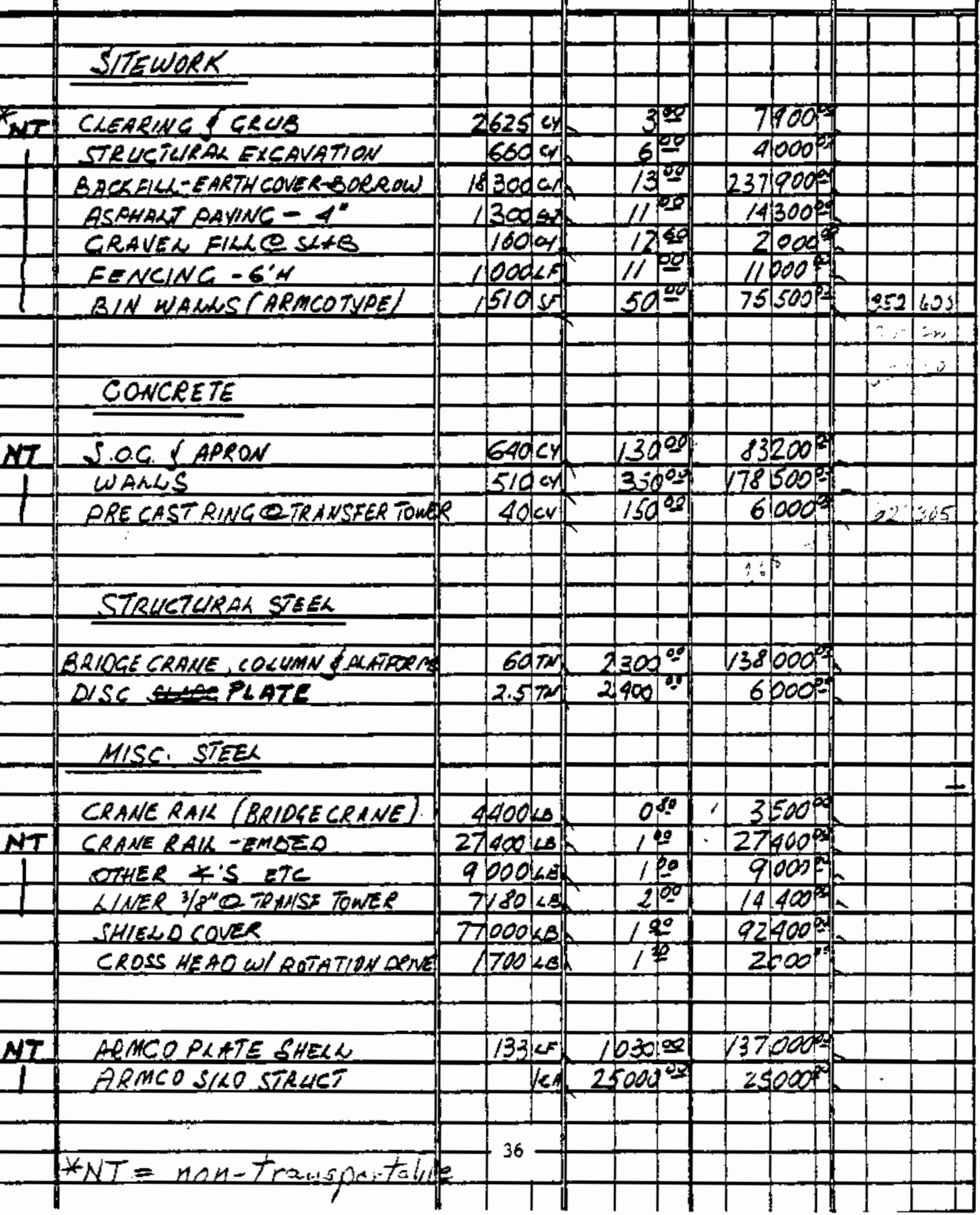




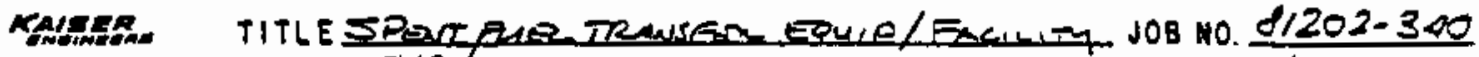

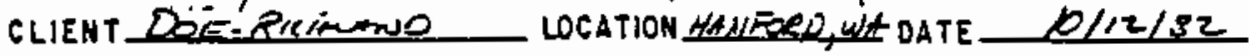
SUBJECT BY_ MY

2

3

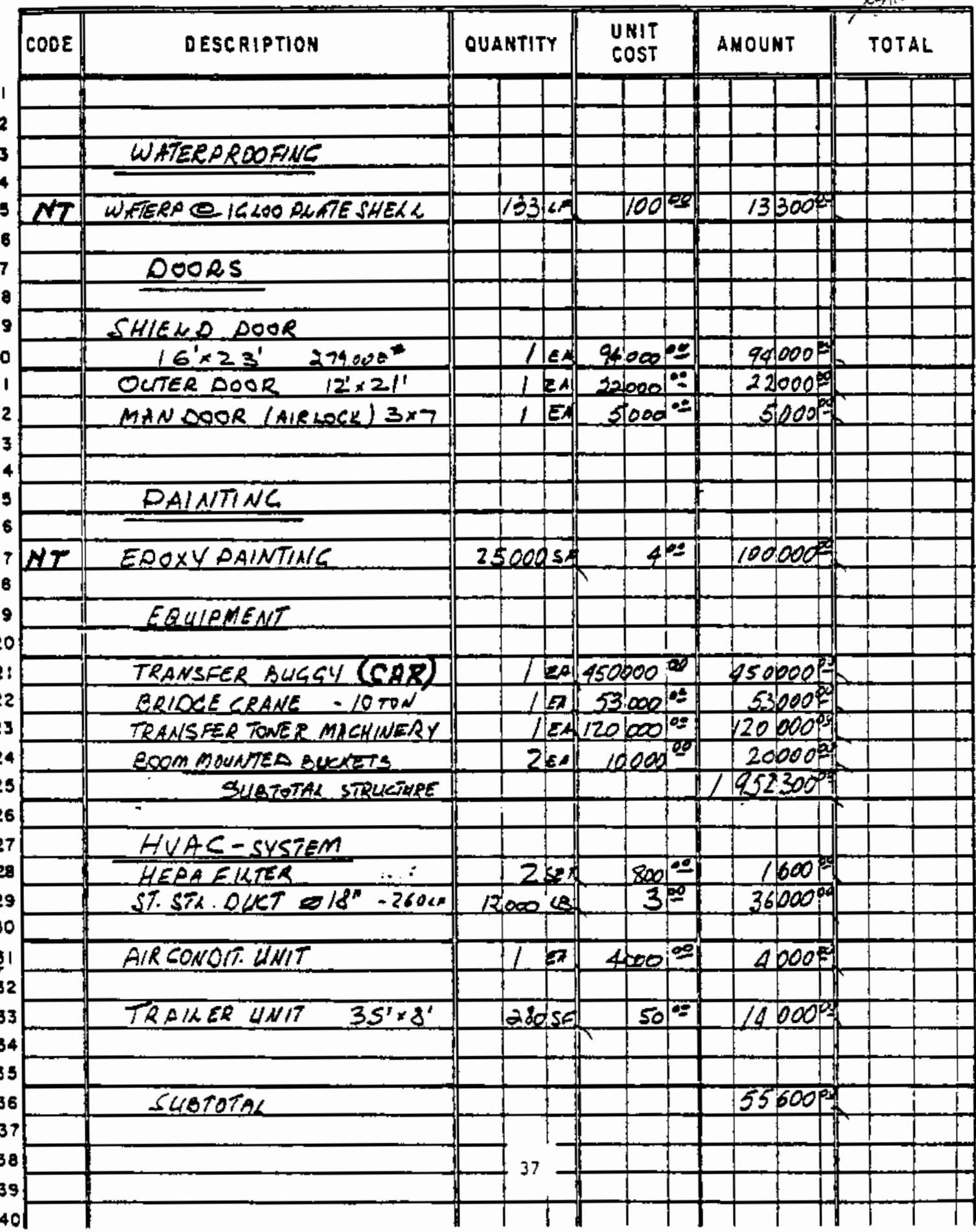


FAVFIT

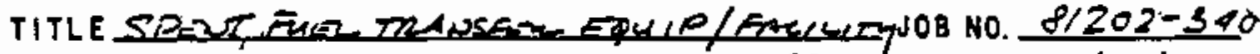
CLIENT DOE -Pratix DO LOCATION HAMFORD, WA DATE _ 10/2/8Z

SUBJECT

BY $M Y$ SHEET 3 OF 4

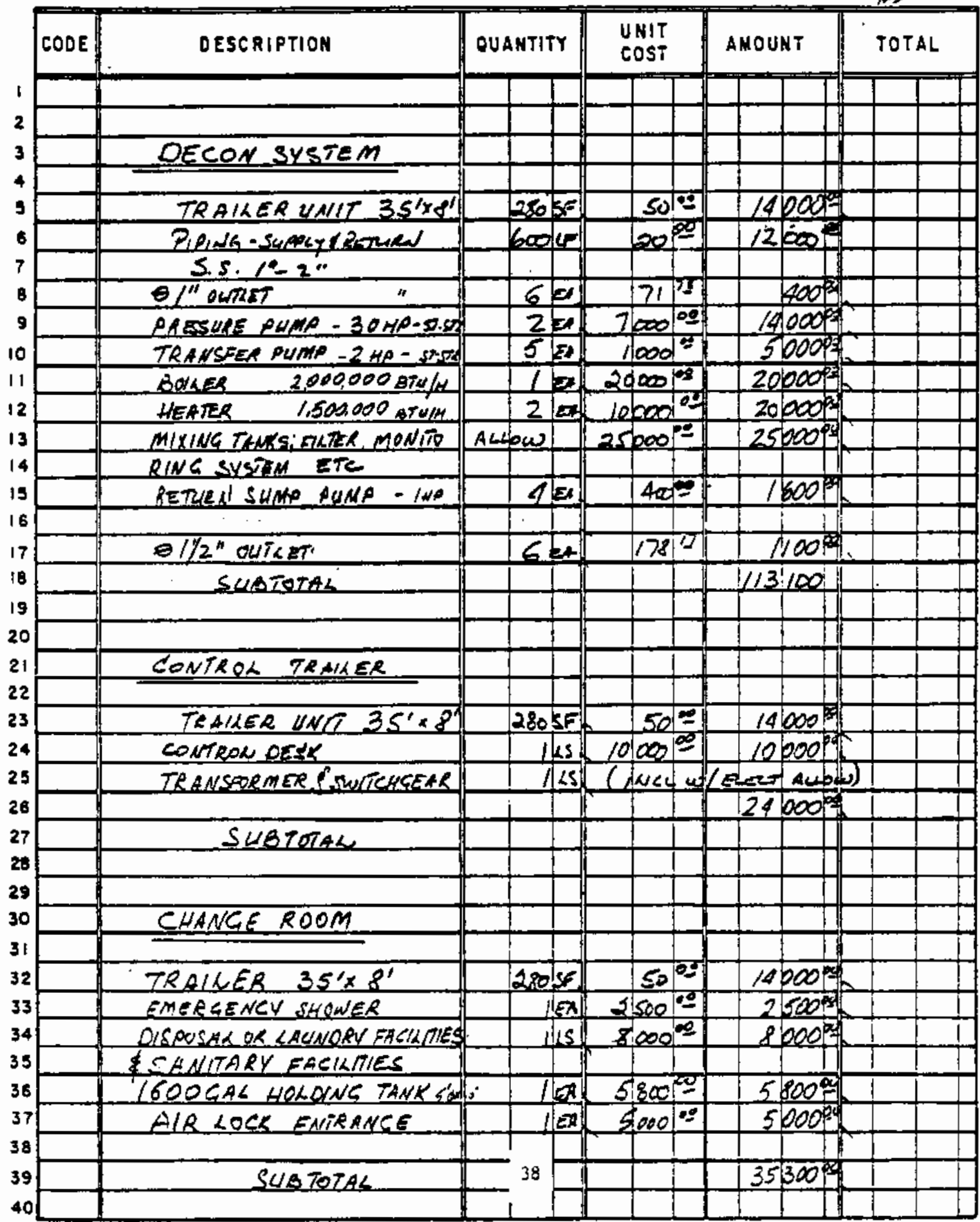




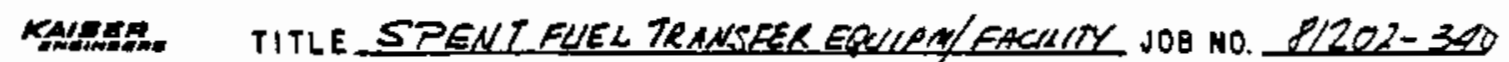
CLIENT DOERECHA DOCATION_ DATE_ 10/12/82 SUBJECT SHEET_L $\triangle \frac{M Y}{-4}$

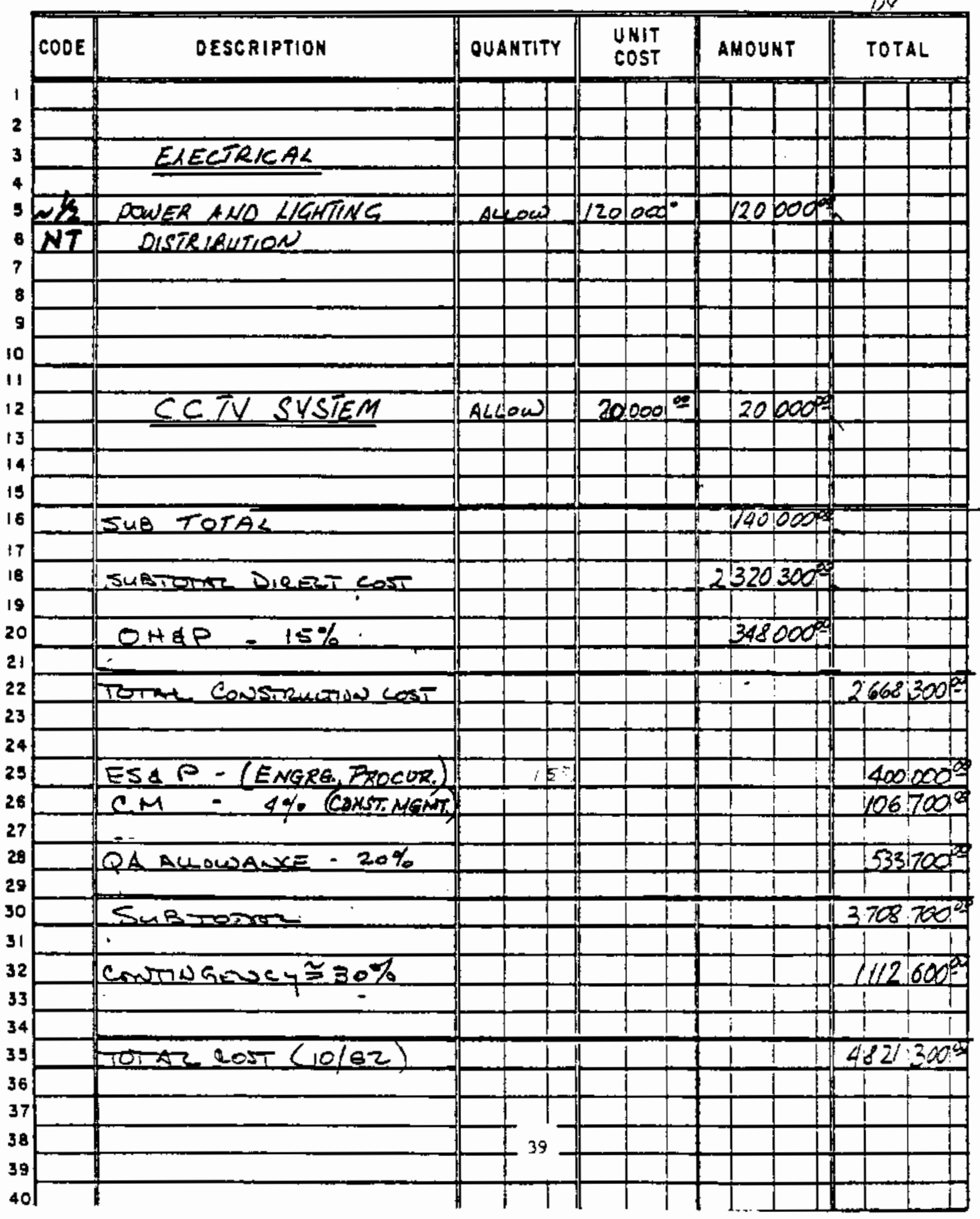




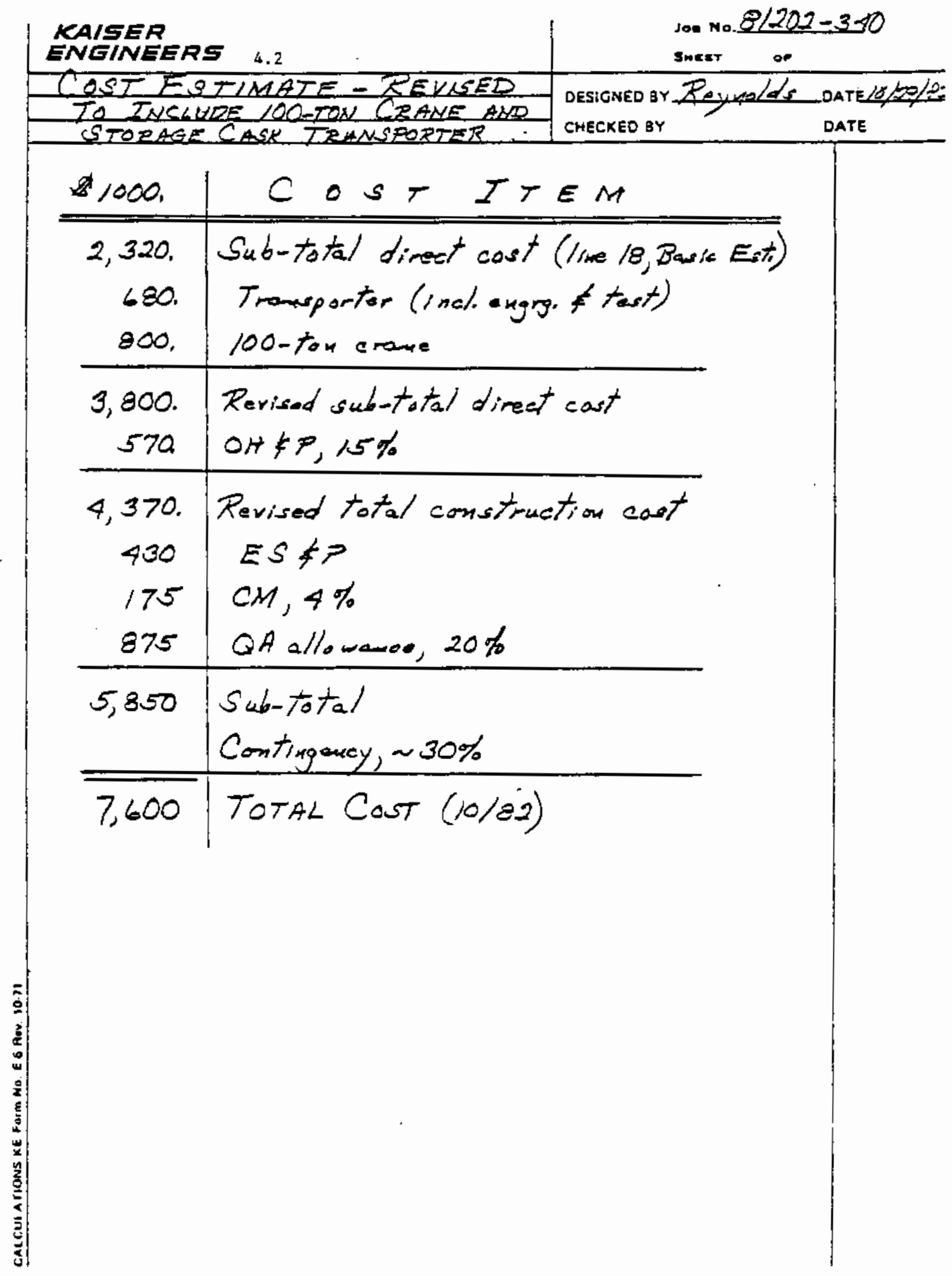

H. 9 


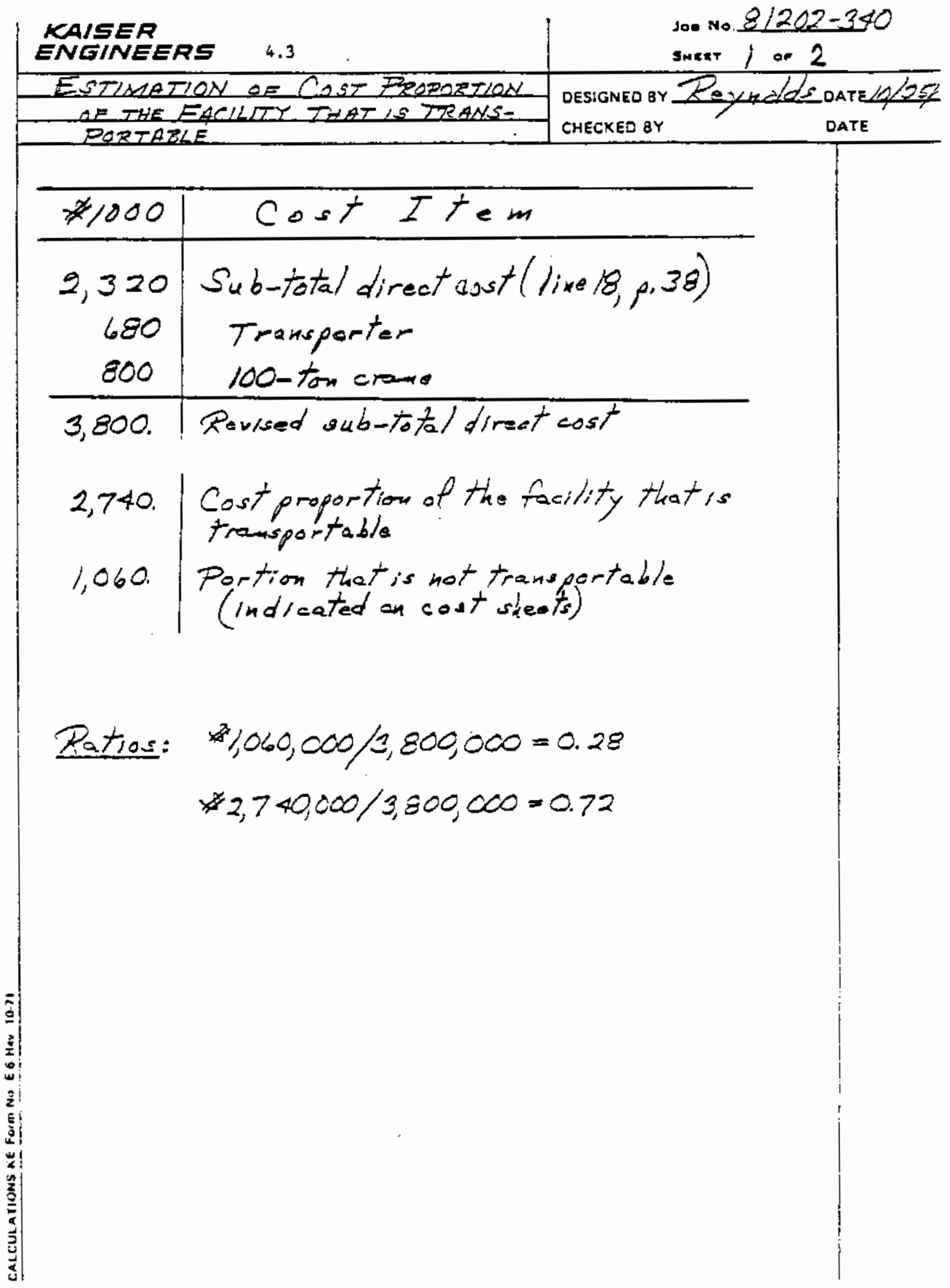

H. 10 


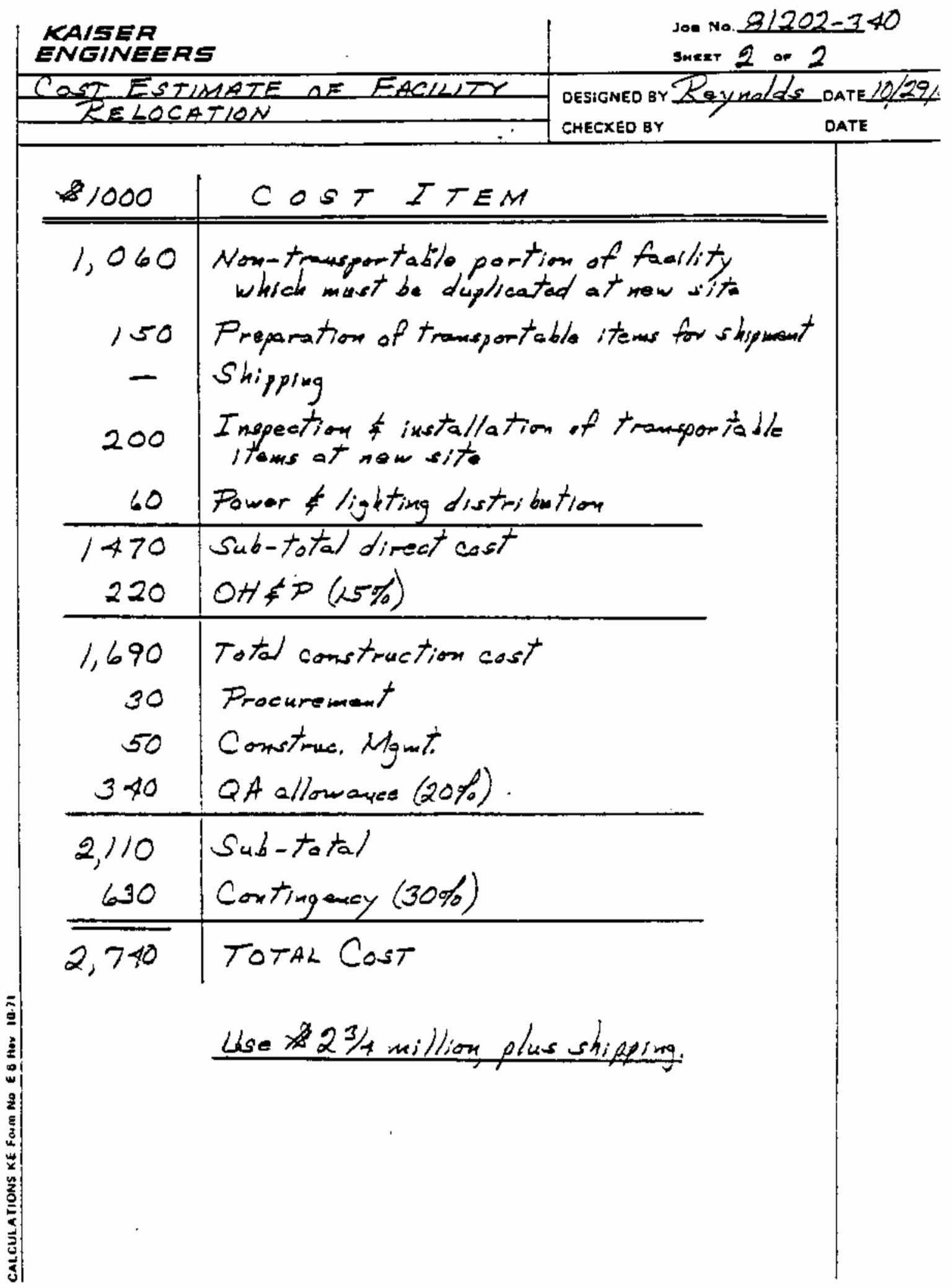

H. 11 


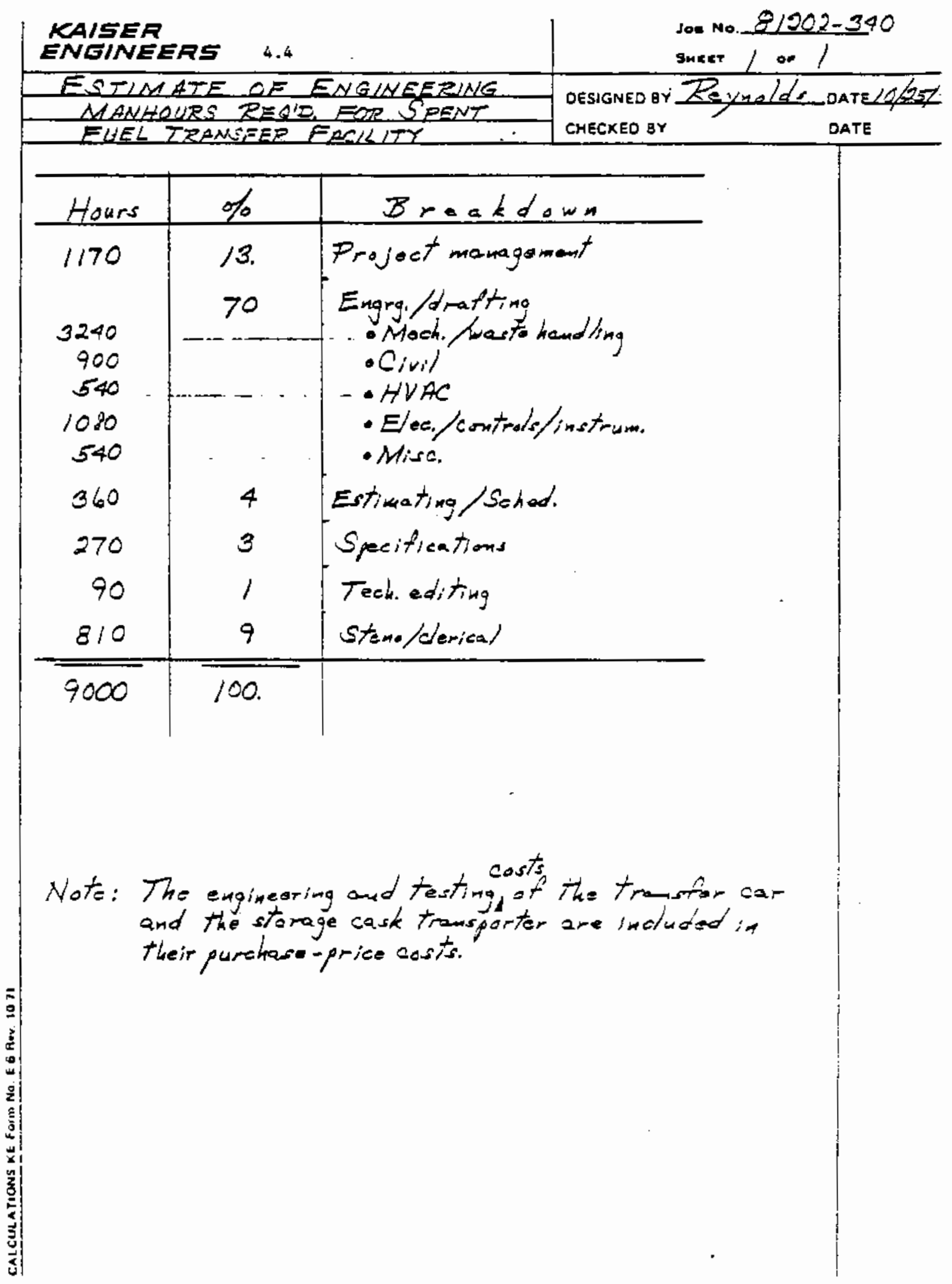

H. 12 


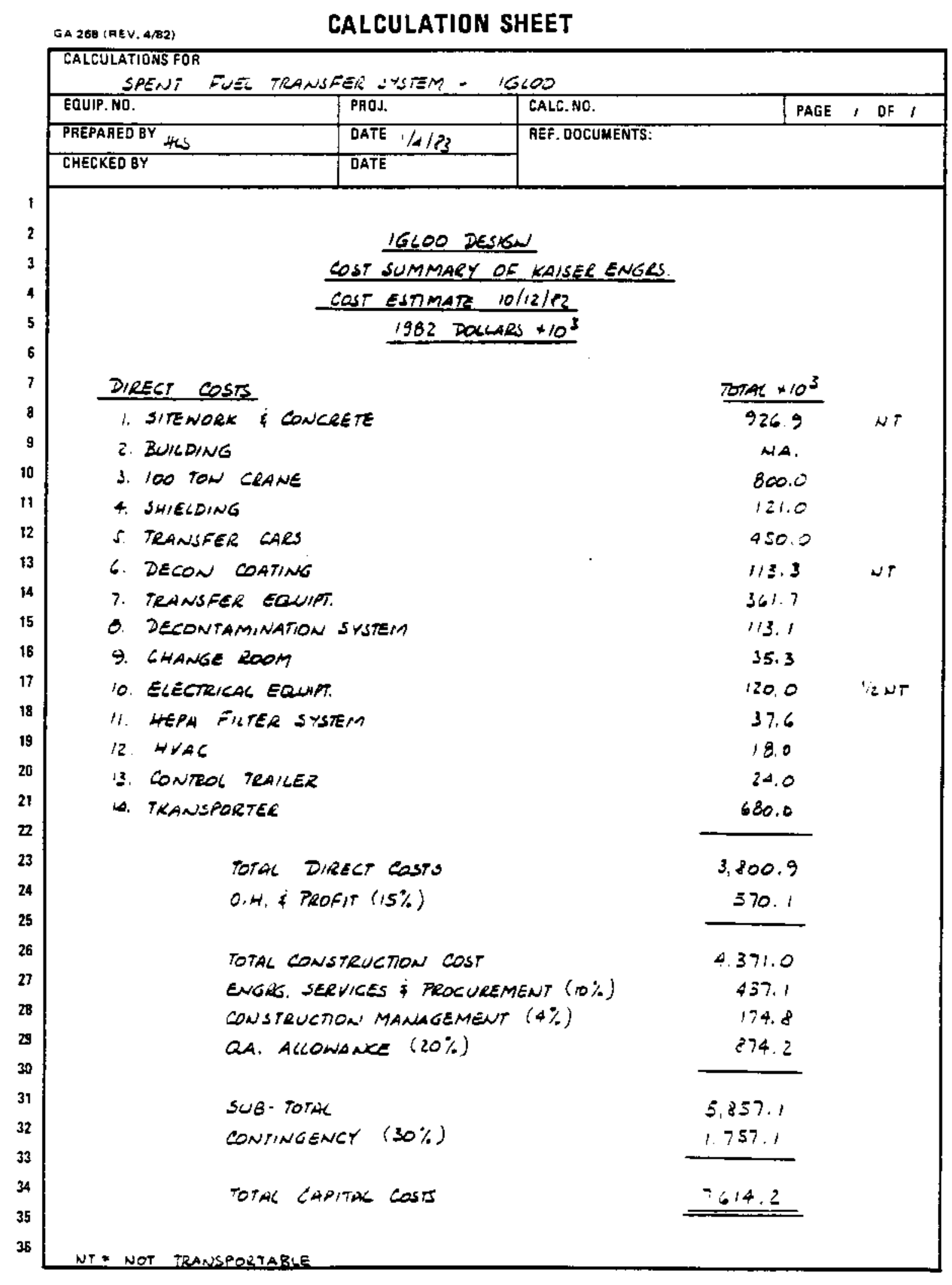

H. 13 


\section{REFERENCES FOR APPENDIX H}

Griffin, R. and M. H. Spritzer. January 1983. Preconceptual Design of Intercask Transfer Equipment. GA Technologies, Inc., San Diego, California.

Reynolds, R. K. October 1982. Spent Fuel Transfer Facility - Concept Study. Raymond Kaiser Engineers, 0akland, California. 


\section{DISTRIBUTION}

No. of

Copies

OFFSITE

M. J. Lawrence

Nuclear Waste Policy Act Project Office

U.S. Department of Energy NE -43

Washington, OC 20545

K. A. Klein, Director

Nuclear Waste Policy Act Project office

U.S. Department of Energy NE $-4,3$

Washington, DC 20545

J. H. Carlson

Nuclear Waste Policy Act

Project Dffice

U.S. Nepartment of Energy

NE-43

Washington, DC 20545

S. P. Schneider

Nuclear Waste Policy Act

Project Office

U.S. Department of Energy

NE -43

Washington, nC. 20545

Len Lanni

Magnetic Fusion and Nuclear Division

U.S. Department of Energy

San Francisco Operations Office

1333 Broadway

nakland, CA 94612

R. O. Nelson

DP $331-M S$ 4B026

II.S. Department of Energy

1000 Independence Ave., S.W.

Washington, DC 20585

DOE Technical Information Center
No. of

Copies

Connor Matthews

U. S. Department of Energy

Oak Ridge Operations Office

P. 0. Box E

Oak Ridge, TN 37830

Don vieth

U.S. Nepartment of Energy

P.n. Box 14100

Las Vegas, NV 89114

W. L. Godfrey

Allied-General Nuclear Services

P.ก. Box 847

Barnwel1, Sf. 29812-0847

D. W. Ketchen

G.A. Technologies, Inc.

P.n. Rox 81608

San 0iego, CA 92138

R. M. Jefferson

Sandia National Laboratories

Transportation Technology Center

P.n. Box 5800

Albuquerque, NM 87185

G. P. Osborne

Kaiser Engineers Hanford Co.

P. O. Box 888

Richland, WA 99352

R. K. Reynolds

Raymond Kaiser Engineers

30 Lakeside Drive

P.0. Box 23210

nakland, CA 94623

R. Griffin

G.A. Technologies, Inc.

P.n. Box 81608

San niego, CA 92138 
No, of

Copies

M. H. Spritzer

G.A. Technologies, Inc.

P.0. Box 81608

San niego, CA 92138

R. W. Lambert

Electric Power Research Institute

$3412 \mathrm{Hillview}$ Avenue

Palo Alto, CA 94303

\section{NNSI TE}

6 DOE Richland Operations Office

P. A. Craig (4)

H. E. Ransom

J. J. Schreiber

Human Affairs Research Center

T. Overcast

46 Pacific Northwest Laboratory

H. B. Andrews

K. R. Ames

N. M. Burleigh

T. D. Chikalla

B. M. Cole

P. M. Naling

R. M. Fleischman

J. F. Fletcher

A. L. Franklin

D. L. Gale
No. of

Copies

Pacific Northwest Laboratory

(contd)

R. J. Hall (2)

D. K. Kreid

G. M. Holter

H. S. Kelly

R. C. Liikala

H. D. Massey

P. N. McDuffie

G. W. McNair

J. L. MCElroy

3. F. Nesbitt

D. F. Newman

D. R. Payson/J. Manko

R. E. Rhoads

K. J. Schneider (10)

R. L. Shaub

M. J. Sherbin

R. I. Smith

L. D. Williams

J. R. Young

Publishing Coordination (2)

Technical Information (5) 